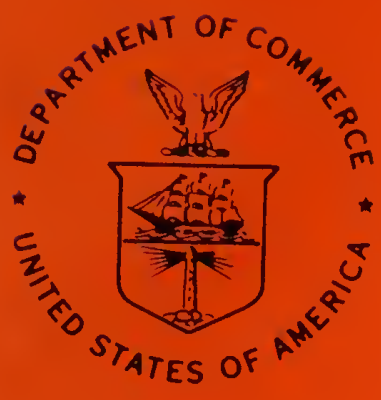

\title{
Synopsis of Biological Data on Bonitos of the Genus Sarda
}

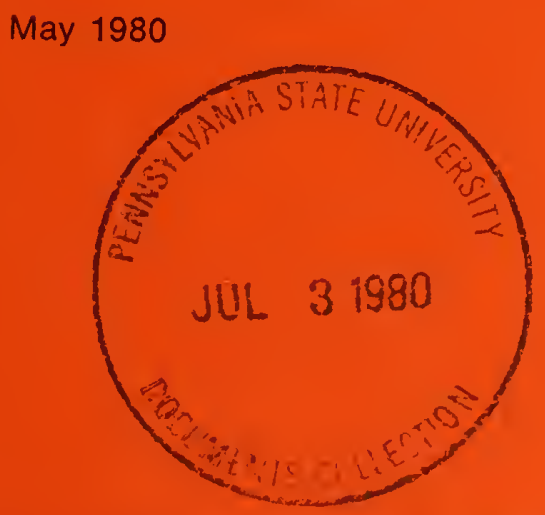

\section{FAO Fisheries \\ Synopsis No. 118}

NMFS/S 118

SAST - Sarda

175(01) 001

U.S. DEPARTMENT OF COMMERCE National Oceanic and Atmospheric Administration National Marine Fisheries Service 



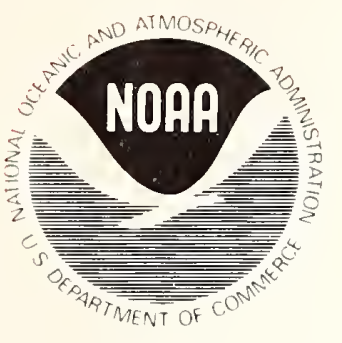

\title{
NOAA Technical Report NMFS Circular 432 Synopsis of Biological Data on Bonitos of the Genus Sarda
}

\author{
Howard O. Yoshida
}

May 1980

FAO Fisheries Synopsis No. 118

U.S. DEPARTMENT OF COMMERCE

Philip M. Klutznik, Secretary

National Oceanic and Atmospheric Administration

Richard A. Frank, Administrator

National Marine Fisheries Service

Terry L. Leitzell, Assistant Administrator for Fisheries 
The National Marine Fisheries Service (NMFS) does not approve, recommend or endorse any proprietary product or proprietary material mentioned in this publication. No reference shall be made to NMFS, or to this publication furnished by NMFS, in any advertising or sales promotion which would indicate or imply that NMFS approves, recommends or endorses any proprietary product or proprietary material mentioned herein, or which has as its purpose an intent to cause directly or indirectly the advertised product to be used or purchased because of this NMFS publication. 


\section{CONTENTS}

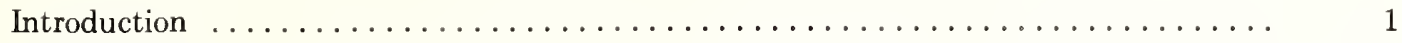

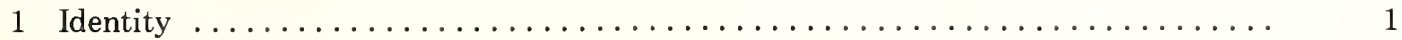

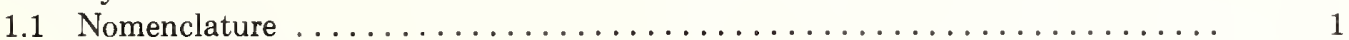

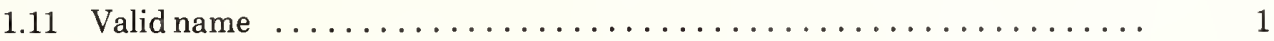

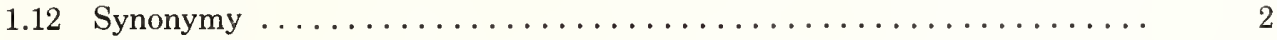

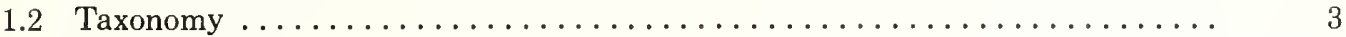

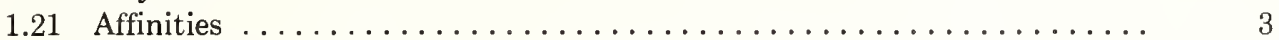

1.22 Taxonomic status $\ldots \ldots \ldots \ldots \ldots \ldots \ldots \ldots \ldots \ldots \ldots \ldots \ldots \ldots \ldots$

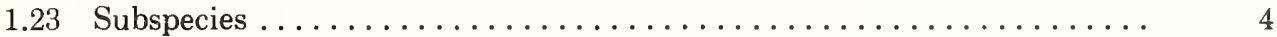

1.24 Standard common names, vernacular names $\ldots \ldots \ldots \ldots \ldots \ldots \ldots \ldots$

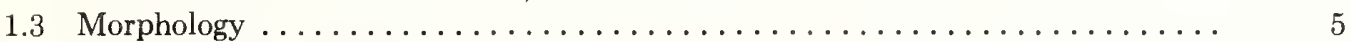

1.31 External and internal morphology $\ldots \ldots \ldots \ldots \ldots \ldots \ldots \ldots \ldots \ldots$

*1.32 Cytomorphology

1.33 Protein specificity $\ldots \ldots \ldots \ldots \ldots \ldots \ldots \ldots \ldots \ldots \ldots \ldots \ldots \ldots \ldots \ldots \ldots$

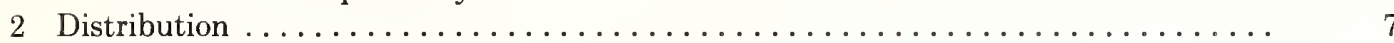

2.1 Total area $\ldots \ldots \ldots \ldots \ldots \ldots \ldots \ldots \ldots \ldots \ldots \ldots \ldots \ldots \ldots \ldots \ldots \ldots$

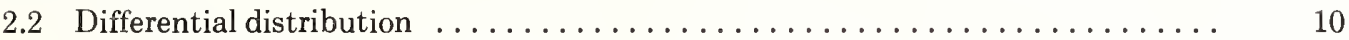

2.21 Spawn, larvae, and juveniles . . . . . . . . . . . . . . . 10

2.22 Adults ..................................... 16

2.3 Determinants of distribution changes $\ldots \ldots \ldots \ldots \ldots \ldots \ldots \ldots \ldots \ldots$

*2.4 Hybridization

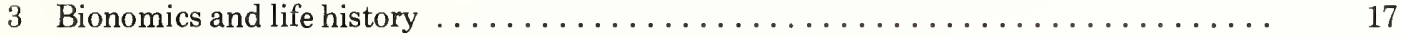

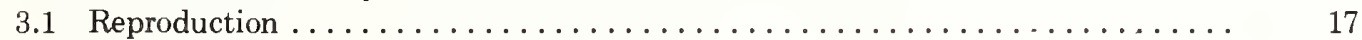

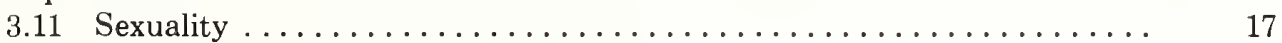

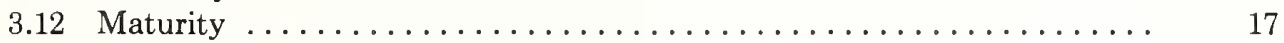

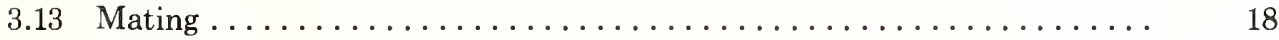

3.14 Fertilization .............................. 18

3.15 Gonads ...................................... 18

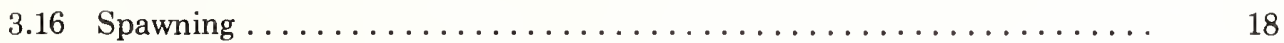

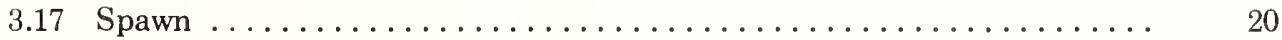

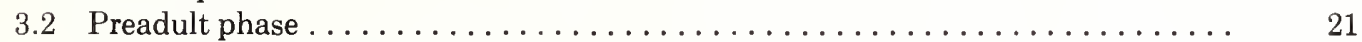

3.21 Embryonic phase ............................... 21

3.22 Larvae and adolescent phase ....................... 21

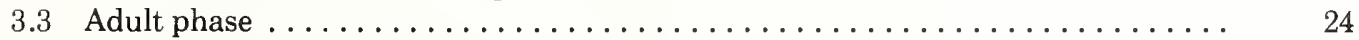

3.31 Longevity .................................... 24

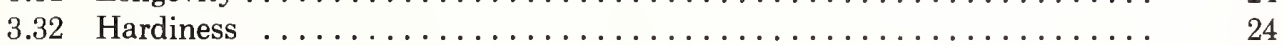

3.33 Competitors ................................ 24

*3.34 Predators

3.35 Parasites, diseases, injuries, and abnormalities $\ldots \ldots \ldots \ldots \ldots \ldots \ldots \ldots$

3.4 Nutrition and growth . . . . . . . . . . . . . . . . . . . . . . . . . . 27

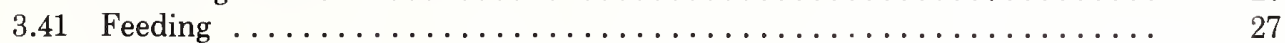

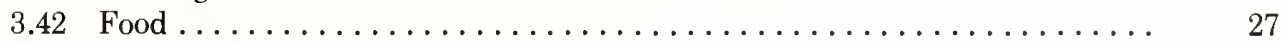

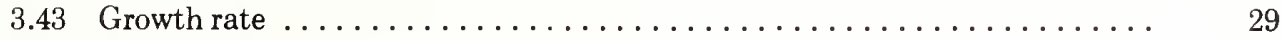

*3.44 Metabolism

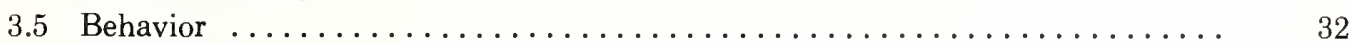

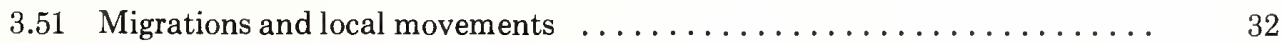

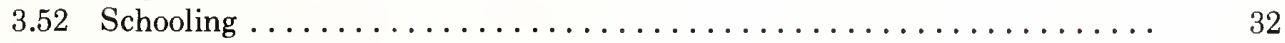

3.53 Responses to stimuli $\ldots \ldots \ldots \ldots \ldots \ldots \ldots \ldots \ldots \ldots \ldots \ldots \ldots \ldots \ldots \ldots$

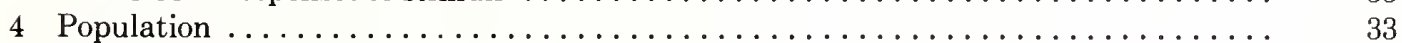

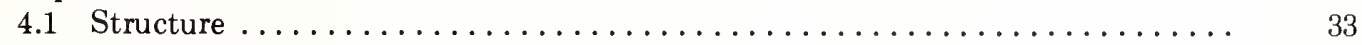

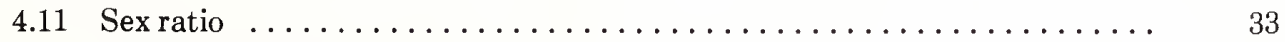

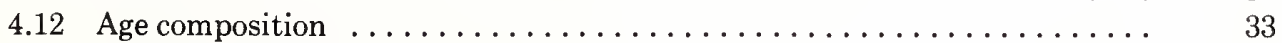

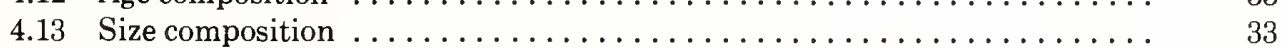

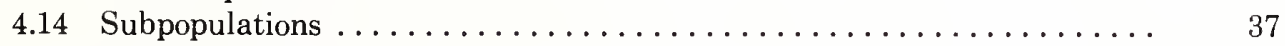

4.2 Abundance and density . . . . . . . . . . . . . . . . . . . . . 38

*4.3 Natality and recruitment

*4.31 Reproduction rates 
*4.32 Factors affecting reproduction

*4.33 Recruitment

4.2 Mortality and morbidity

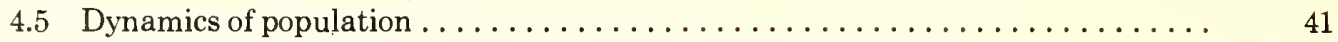

4.6 The population in the community and the ecosystem .............. 41

5 Exploitation ........................................... 42

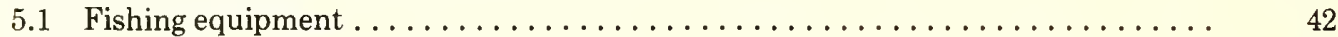

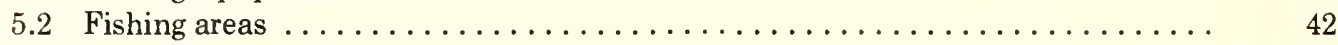

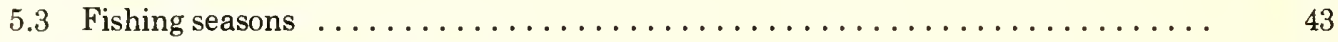

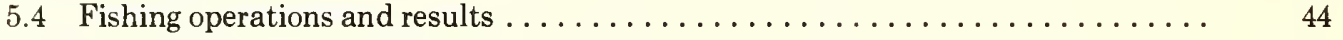

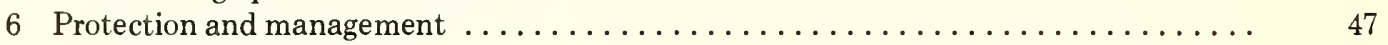

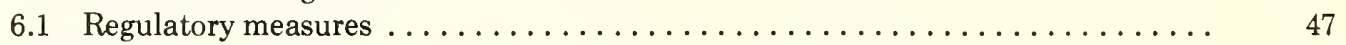

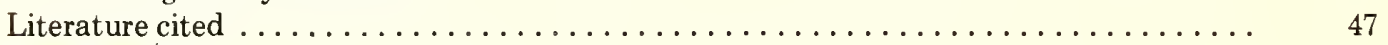

*No information available. 


\title{
Synopsis of Biological Data on Bonitos of the Genus Sarda
}

\author{
HOWARD O. YOSHIDA ${ }^{1}$
}

\begin{abstract}
Published and some unpublished information on the biology and resources of the three species of Sarda, S. australis, S. chiliensis, and S. sarda, are compiled, reviewed, and analyzed in the FAO species synopsis style.
\end{abstract}

\section{INTRODUCTION}

In response to a growing demand for tuna, increased effort has been expended over the years to harvest the commercially important large tunas throughout the world's oceans. The effort has increased to such an extent that some of the tunas are in danger of being overexploited. Examples of these are the yellowfin tuna, Thunnus albacares, in the eastern tropical Pacific, which has been under management now for a number of years, and the albacore, T. alalunga, of the South Pacific Ocean (Skillman 1975). To meet the demand for tuna and at the same time avoid the overexploitation of important resources, attention has been focused on tuna resources that are relatively underutilized, such as the skipjack tuna, Katsuwonus pelamis. In addition, some of the smaller tunas or tunalike species such as the bonitos, Sarda spp., which up to now have had mixed acceptance in the marketplace, are gaining more attention.

The bonitos are not an entirely unutilized resource. The total world catch of bonitos has ranged from about 92,200 to $140,500 \mathrm{t}$ (metric tons) in the 10 -yr period from 1964 to 1973 (Food and Agriculture Organization of the United Nations 1970, 1974). As indicated above, however, bonitos have varying acceptance throughout the world. In the Mediterranean and Black Sea countries, Sarda sarda is of great importance and has been the object of a fishery for many years (Demir 1963). In Chile, in contrast to earlier years when $S$. chiliensis contributed insignificant amounts to the total fish processed, more and more bonitos have been processed into canned products in recent years (Barrett 1971). In California waters, S. c. lineolata has been exploited since the beginning of the century and there are indications that the California Indians utilized this species before the arrival of Europeans $\left(\mathrm{Klawe}^{2}\right)$. It does not have much commercial value, however, and the California tuna in-

${ }^{1}$ Southwest Fisheries Center, National Marine Fisheries Service, NOAA, Honolulu, HI 96812.

${ }^{2}$ W. L. Klawe, Inter-American Tropical Tuna Commission, La Jolla, CA 92037, pers. commun. February 1978. dustry has accepted bonito more from necessity than by choice (Frey 1971). The flesh of $S$. orientalis is considered rather soft and inferior in quality, and except in Kyushu, where it is caught as an adjunct to the mackerel and other pelagic species, bonitos are not especially sought after in Japan (Kikawa and Staff of the Nankai Fisheries Research Laboratory, Kochi, Japan 1963). And in Australia, the edible qualities of $S$. australis are not highly regarded (Grant 1972).

The purpose of this report is to review and analyze all the information available on the biology and resources of the bonitos throughout the world, following the FAO (Food and Agriculture Organization of the United Nations) species synopsis style (Rosa 1965). This report is based on published papers, in general, and the FAO species synopses on the bonitos (Demir 1963; Kikawa and Staff of the Nankai Fisheries Research Laboratory, Kochi, Japan 1963; Idyll and de Sylva 1963; Silas 1963) were heavily relied on. Ancieta (1964) also prepared a species synopsis on $S$. chiliensis in Peruvian waters in the FAO species synopsis style.

\section{IDENTITY}

\subsection{Nomenclature}

\subsection{Valid name}

The confusion on the number of valid species in the genus Sarda has been cleared and, basically, four allopatric species are now recognized (Collette and Chao 1975). These are the southeast Australian Sarda australis (Macleay 1880), the eastern temperate Pacific Sarda chiliensis (Cuvier 1831), the tropical Indo-Pacific Sarda orientalis (Temminck and Schlegel 1844), and the Atlantic Sarda sarda (Bloch 1793) (Fig. 1).

The Australian bonito was originally described as Pelamys australis Macleay 1880. Type-locality: Port Jackson, Sydney, Australia. Holotype: Macleay Museum, University of Sydney F-333, now at Australian Museum, Sydney.

The eastern temperate Pacific Sarda chiliensis was 
(a)

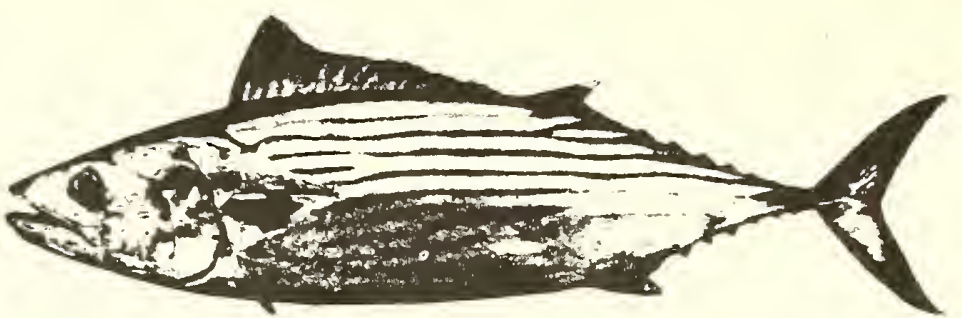

(b)

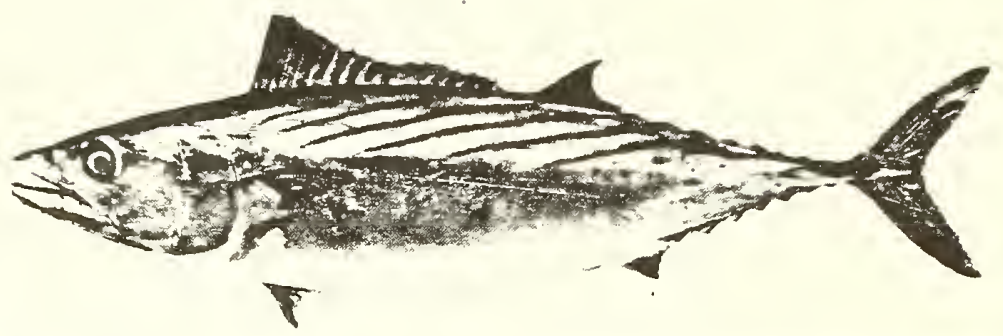

(c)

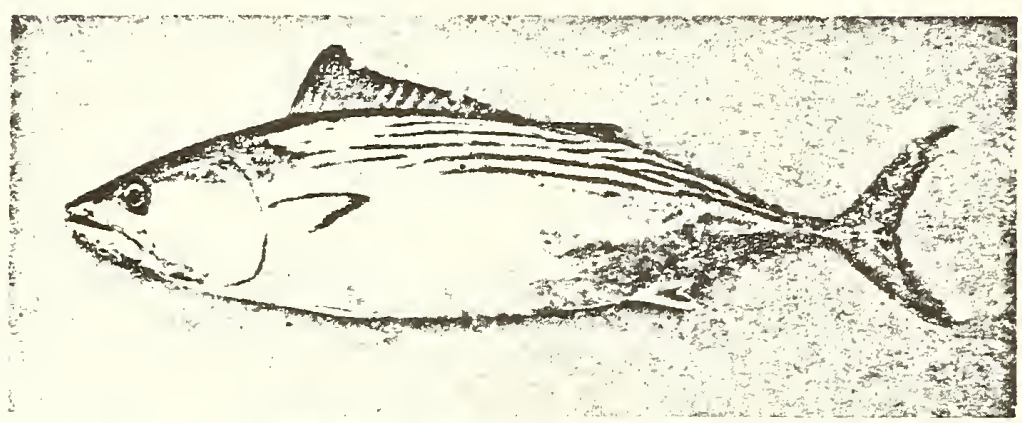

(d)

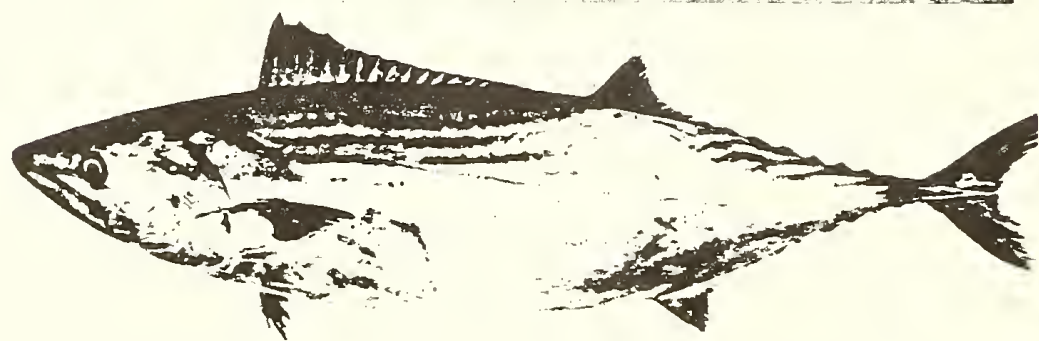

Figure 1.-The four species of Sarda: (a) Sarda australis (from Serventy 194la, plate 4); (b) Sarda chiliensis (from Frey 1971); (c) Sardo orientalis (from Kikawa and Staff of the Nankai Regional Fisheries Research Laboratory 1963, fig. 1); (d) Sarda sarda (from Demir 1963, fig. la). first described as Pelamys chiliensis Cuvier 1831. Typelocality: Valparaiso, Chile. Holotype: Muséum National d'Histoire Naturelle, Paris A.5608.

The tropical Indo-Pacific bonito was first described as Pelamys orientalis Temminck and Schlegel 1844. Typelocality: Japan. Three syntypes are in the Rijksmuseum van Natuurlijke Historie, Leiden, of which Boeseman (1947, 1964) selected the largest as lectotype, RMNH 2286.

The Atlantic bonito Sardo sarda was first described as Scomber sarda Bloch 1793. No types known to be extant.

\subsection{Synonymy}

The synonymies given below are modified versions of those given by Collette and Chao (1975) and do not distinguish objective and subjective synonyms.

\section{Sarda australis (Macleay)}

Pelamys australis Macleay 1880 (Port Jackson, Sydney, Australia)

Pelamys schlegeli McCoy 1888 (Prince Phillip Bay, Victoria, Australia)

Pelamys chilensis (not of Cuvier 1831) Ogilby 1893 (New South Wales, Australia)

Sarda chilensis (not of Cuvier 1831). Waite 1904 (New South Wales, Australia)

Sarda chiliensis (not of Cuvier 1831). McCulloch 1922 (New South Wales, Australia)

Sarda orientalis (not of Temminck and Schlegel 1844). Lord 1927 (Tasmania, Australia)

Sarda australis. Walford 1936

Sarda chiliensis australis. Roughley 1951 (Queensland, New South Wales, and Victoria, Australia) 
Sarda chilensis australis. Silas 1964 (eastern Australia)

\section{Sarda chiliensis (Cuvier)}

Following Collette and Chao (1975) the synonymy for S. chiliensis is split for the southeast Pacific S. chiliensis chiliensis and the northeast Pacific S. chiliensis lineolata (see section 1.23 Subspecies).

\section{Sarda chiliensis chiliensis (Cuvier)}

Pelamys chiliensis Cuvier in Cuvier and Valenciennes 1831 (Valparaiso, Chile)

Pelamys chilensis. Günther 1860

Sarda chilensis. Starks 1906 (Callao, Peru)

Sarda chiliensis. Walford 1936

Sarda sarda chiliensis. Buen 1958 (Chile)

Sarda chilensis chilensis. Vildoso 1963 (Peru)

Sarda sarda chilensis. Sánchez and Lam 1970 (Peru)

Sarda chiliensis chiliensis. Kuo 1970 (Peru)

Sarda chiliensis lineolata (Gerard)

Pelamys lineolata Girard 1859 (San Diego, Calif.)

Pelamys chilensis. Günther 1860

Sarda chilensis. Jordan and Gilbert 1882

Sarda lineolata. Walford 1936

Sarda stockii David 1943 (Santa Monica Mountains, Calif.)

Sarda chiliensis. Chabanaud 1944

Sarda chiliensis lineolata. Kuo 1970 (Calif.)

Sarda orientalis (Temminck and Schlegel)

\section{Indo-West Pacific}

Pelamys orientalis Temminck and Schlegel 1844 (Japan)

Pelamys chilensis (not of Cuvier 1831), Day 1878

Sarda chilensis var. orientalis. Steindachner and Döderlein 1884 (Japan)

Sarda orientalis. Jordan and Snyder 1900 (Tokyo)

Sarda chilensis (not of Cuvier 1831), Jordan and Snyder 1904 (Honolulu)

Sarda chiliensis (not of Cuvier 1831), Fowler 1938 (Honolulu) .

Sarda orientalis serventyi Whitley 1945 (Western Australia)

\section{Eastern Pacific}

Sarda chilensis (not of Cuvier 1831), Gilbert and Starks 1904 (Panama City)

Sarda chiliensis (not of Cuvier 1831), Herre 1936 (Galápagos)

Sarda velox Meek and Hildebrand 1923 (Panama City)

Sarda orientalis. Fraser-Brunner 1950
Sarda sarda (Bloch)

Scomber sarda Bloch 1793 (Europe)

Scomber mediterraneus Bloch and Schneider 1801

Scomber palamitus Rafinesque 1810 (Palermo, Sicily)

Scomber ponticus Pallas 1811 (Crimea)

Thynnus pelamis. Risso 1826 (Nice)

Thynnus sardus. Risso 1826 (Nice)

Thynnus brachypterus Cuvier 1829

Sarda sarda. Cuvier 1829

Pelamys sarda. Cuvier in Cuvier and Valenciennes 1831

(Cape Verde Islands and Brazil)

Palamita sarda. Bonaparte 1831

Pelamis sarda. Valenciennes 1844 (Canary Islands)

Sarda pelamys. Gill 1862

Sarda mediterranea. Jordan and Gilbert 1882 (both sides of Atlantic)

Sarda pelamis. Smitt 1892 (Scandinavia)

1.2 Taxonomy

1.21 Affinities

$$
\begin{aligned}
& \text { Suprageneric } \\
& \text { Phylum Chordata } \\
& \text { Subphylum Vertebrata } \\
& \text { Superclass Gnathostomata } \\
& \text { Class Osteichthyes } \\
& \text { Subclass Actinopterygii } \\
& \text { Order Perciformes } \\
& \text { Suborder Scombroidei } \\
& \text { Family Scombridae } \\
& \text { Subfamily Scombrinae } \\
& \text { Tribe Sardini }
\end{aligned}
$$

Generic

Genus Sarda Cuvier 1829.

The generic concept of Collette and Chao (1975) is followed.

Sarda Cuvier 1829:199 (type-species Scomber sarda Bloch 1793 by monotypy).

Pelamys Cuvier in Cuvier and Valenciennes 1831:149 (type-species Scomber sarda Bloch 1793 by original designation).

Palamita Bonaparte 1831:173 (substitute name for Pelamys Cuvier 1831 preoccupied by Pelamys Oken 1816 in Reptilia, Hydrophiidae; therefore, takes the same type-species Scomber sarda Bloch 1793).

Creotroctes Gistel 1848, p. X (type-species Scomber sarda Bloch 1793; substitute name for Sarda Cuvier 1829).

The species of Sarda all have several stripes dorsally, ranging from horizontal to oblique in orientation. The intestine runs straight from the stomach to the anus and there are two intermuscular bones on each side of the back of the skull. The bony caudal peduncle keels are well developed as in higher tunas, but are divided into 
anterior and posterior sections on each vertebra; the spleen is large and prominent in ventral view; the right and left lobes of the liver are both much longer than the middle lobe. The body is fusiform instead of being more laterally compressed. Collette and Chao (1975) compared the similarities and differences of the genus Sarda with the other genera of bonitos within the tribe Sardini.

Collette and Chao (1975) recognized four allopatric species of Sarda: S. australis, S. chiliensis, S. orientalis, and S. sarda.

\section{Specific}

A summary of characters distinguishing the four species of Sarda is given in Table 1.

A key to the species of Sarda as adapted from that given for the Sardini by Collette and Chao (1975) is presented below.

Key to the species of Sarda

1a Spines in first dorsal fin 20-23; total vertebrae

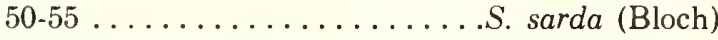

1b Spines in first dorsal fin 17-19; total vertebrae $43-46 \ldots \ldots \ldots \ldots \ldots \ldots \ldots \ldots . \ldots . \ldots 2$ 2a Total gill rakers on first arch 8-13; supramaxilla narrow .. S. orientalis (Temminck and Schlegel)

2 b Total gill rakers on first arch 19.27; supramaxilla wider $\ldots \ldots \ldots \ldots \ldots$

3a Total gill rakers on first arch 19-21; pectoral rays $25-27$, modally 26 ; teeth sometimes present on vomer; length of first dorsal base 315 343 thousandths of fork length; maxilla 503539 thousandths of head length ........ .................. australis (Macleay)

3 b Total gill rakers on first arch $23-27$; pectoral rays $22-26$, modally 24 or 25 ; teeth never present on vomer; length of first dorsal base 267-314 thousandths of fork length; maxilla 460-503 thousandths of head length ...... $\ldots \ldots \ldots \ldots \ldots$. . chiliensis (Cuvier)

\subsection{Taxonomic status}

As already noted four allopatric species of Sarda are recognized (Collette and Chao 1975).

\subsection{Subspecies}

Two subspecies of the eastern temperate Pacific Sarda

Table 1.-Summary of characters showing differences and similarities among the four species of Sarda. (From Collette and Chao 1975, table 17.)

\begin{tabular}{|c|c|c|c|c|}
\hline Character (reference) & S. sarda & S. australis & S. chiliensis & S. orientalis \\
\hline Lamellae in nasal rosettes & $22-33(\bar{x} 26.5)$ & $34-39(\bar{x} 37.2)$ & $21-30(\bar{x} 25.4)$ & $25-36(\bar{x} 31.9)$ \\
\hline Vomerine teeth present & sometimes & sometimes & never & never \\
\hline Upper jaw teeth & $16-26$ & $16-26$ & $18-30(\bar{x} 23.5)$ & $12-20(\bar{x} 15.5)$ \\
\hline Lower jaw teeth & $12-24(\bar{x} 16.0)$ & $11-20(\bar{x} 14.5)$ & $4-25(\dot{x} 19.2)$ & $10-17(\bar{x} 13.0)$ \\
\hline Palatine teeth & $8-21(\bar{x} 12.3)$ & $7-14(\bar{x} 10.7)$ & $9-22(\bar{x} 15.2)$ & $8-19(\bar{x} 11.9)$ \\
\hline Supramaxilla width & intermediate & intermediate & wide & narrow \\
\hline Ectopterygoid-dorsal portion & pointed & pointed & pointed & slightly expanded \\
\hline Hyomandibular spine-condyle & $\begin{array}{l}\text { projects beyond } \\
\text { condyle }\end{array}$ & short & short & $\begin{array}{c}\text { projects beyond } \\
\text { condyle }\end{array}$ \\
\hline Angle of hyomandibular spine & about $90^{\circ}$ & about $90^{\circ}$ & greater than $90^{\circ}$ & less than $90^{\circ}$ \\
\hline Elliptical ceratohyal window & present & present & present & $\begin{array}{l}\text { only slight } \\
\text { depression }\end{array}$ \\
\hline Ventral surface of glossohyal & depression present & depression present & depression present & no depression \\
\hline Gill rakers & $16-23$ & $19-21$ & $23-27$ & $8-13$ \\
\hline Vertebrae & $50-55$ & $43-46$ & $43-46$ & $43-46$ \\
\hline Pleural ribs & 24 & $19-23$ & $19-23$ & $19-23$ \\
\hline Intermuscular bones & $31-45$ & $32-36$ & $32-36$ & $32-36$ \\
\hline Keels on vertebrae number & $5-10$ & $5-8$ & $5-8$ & $5-8$ \\
\hline First closed haemal arch & 13 th -15 th vertebra & 13 th- 15 th vertebra & 12 th -14 th vertebra & 12 th- 14 th vertebra \\
\hline $\begin{array}{l}\text { Length of haemal prezygapophyses } \\
\text { and postzygapophyses at precau- } \\
\text { dal-caudal junction }\end{array}$ & $\begin{array}{l}\text { postzygapophyses } \\
\text { longer than } \\
\text { prezygapophyses }\end{array}$ & $\begin{array}{l}\text { postzygapophyses } \\
\text { longer than } \\
\text { prezygapophyses }\end{array}$ & $\begin{array}{l}\text { prezygapophyses } \\
\text { longer than } \\
\text { postzygapophyses }\end{array}$ & $\begin{array}{l}\text { prezygapophyses } \\
\text { longer than } \\
\text { postzygapophyses }\end{array}$ \\
\hline Dorsal spines & $20-23$ & $17-19$ & $17-19$ & $17-19$ \\
\hline Dorsal finlets & modally 8 & modally 7 & modally 8 & modally 8 \\
\hline Anal rays & $14-17$ (modally 15$)$ & 14-17 (modally 15$)$ & 12-15 (modally 14$)$ & 14-16 (modally 15 ) \\
\hline Anal finlets & modally 7 & modally 6 & modally 7 & modally 6 \\
\hline Total anal elements & $\begin{array}{l}19-23 \\
\quad \text { (modally } 21-22)\end{array}$ & $\begin{array}{l}19-23 \\
\quad(\text { modally } 21-22)\end{array}$ & $\begin{array}{l}\text { 18-22 } \\
\quad \text { (modally } 20)\end{array}$ & $\begin{array}{l}20-22 \\
\text { (modally } 21)\end{array}$ \\
\hline Supracleithral notch & wide angle & almost $90^{\circ}$ & wide angle & wide angle \\
\hline Pectoral rays & $23-26$ & $\begin{array}{l}25-27 \\
\quad \text { (modally } 26)\end{array}$ & $\begin{array}{l}22-26 \\
\quad \text { (modally } 24-25)\end{array}$ & $\begin{array}{c}22-26 \\
\text { (modally } 24-25)\end{array}$ \\
\hline Vertical wing of pelvic girdle & $\begin{array}{l}\text { shorter and } \\
\text { wider }\end{array}$ & $\begin{array}{l}\text { shorter and } \\
\text { wider }\end{array}$ & $\begin{array}{l}\text { narrower and } \\
\text { longer }\end{array}$ & $\begin{array}{c}\text { narrower and } \\
\text { longer }\end{array}$ \\
\hline
\end{tabular}


chiliensis are recognized: Sarda chiliensis chiliensis (Cuvier) for the southeastern Pacific population and Sarda chiliensis lineolata (Girard) for the northeastern Pacific population (Collette and Chao 1975).

\subsection{Standard common names, vernacular names}

The common and vernacular names of the species of Sarda are given in Table 2.

\subsection{Morphology}

Collette and Chao (1975) made a detailed study of the morphology of the species of Sarda including color pattern, scales, morphometry, meristics, soft anatomy, and osteology.

\subsection{External and internal morphology}

\section{Sarda australis}

Probably in part because of its restricted geographic range there have been no studies on the use of morphological characters to differentiate subpopulations or on the geographic variation in the morphology of $S$. australis. Collette and Chao (1975) presented data on morphometric characters of $S$. australis (Table 3) which give some indication of individual variation in the characters examined.

\section{Sarda chiliensis}

Although the temperate northeast (S. c. lineolata) and southeast (S. c. chiliensis) Pacific populations of Sarda chiliensis are completely separated geographically, there are few differences between the two populations and anatomically they are virtually identical (Collette and Chao 1975).

Godsil (1954) presented meristic and morphometric data from the northeast Pacific population of $S$. chiliensis. In a later study, Godsil (1955) also presented similar data for bonitos from the southeast Pacific population and made a comparison of the specimens from the two populations. His conclusion was that such differences as existed between specimens of the northeastern and southeastern populations should be considered as varietal or population differences and that both varieties should be assigned to the same species, S. chiliensis.

Collette and Chao (1975) discussed the results of earlier investigators (Walford 1936; Hildebrand 1946; Kuo 1970) who tried to distinguish the two populations by the use of various morphometric characters. They noted that among the meristic characters, the total number of vertebrae was the best character to distinguish the southeast and northeast populations of $S$. chiliensis (Table 4). The mean vertebral count of the northeast population was slightly higher than that of the southeast population. After considering all the published data and their own data, Collette and Chao concluded that "The available data does not convince us that the northeast and southeast Pacific populations are subspecies. However, as the populations are genetically isolated from each other and there are some significant differences, there is practical value in using the available subspecific names, and there is ample historical precedent for the name lineolata for the northwest popu. lation."

\section{Sarda orientalis}

The distribution of Sarda orientalis is widespread in the Indo-Pacific and it is likely that independent populations occur in the many different areas where the species is found. Therefore, as Collette and Chao (1975) indicated, subspecific or populational differences are possible.

Silas (1964) gave meristic and morphometric data from $S$. orientalis collected at Vizhingam on the Kerala coast of India. He summarized his data by $5 \mathrm{~cm}$ size groups but did not make any conclusions as to any differences in body proportions or meristics in the different size groups. Silas also compared published meristic data on $S$. orientalis from various areas in the Indo-Pacific but refrained from drawing any conclusions on subspecific or populational differences. Based on the scattered material available, Collette and Chao (1975) concluded that there appear to be no significant anatomical or meristic differences between any populations of the species. Morphometric data on S. orientalis from Japan and the eastern tropical Pacific are given in Table 5. Godsil (1955) also made detailed morphological studies on $S$. orientalis from the eastern tropical Pacific.

\section{Sarda sarda}

A detailed analysis of the geographic variation in $S$. sarda was done by Collette and Chao (1975). They compared S. sarda occurring in five geographic areas: North and South America, northeast Atlantic (Scandinavia, Atlantic Europe, and the Azores), Mediterranean Sea (including the Black and Adriatic Seas), and the Gulf of Guinea (extending south to South Africa). They found varying meristic and morphometric differences between and among the populations in the five areas. For example, the meristic characters were similar for the two western Atlantic populations as they were for the Mediterranean and Gulf of Guinea populations. In summary, they concluded that there was at least as much justification for recognition of subspecies in $S$. sarda as in $S$. chiliensis, if names had been available for the populations. They stated that more study is needed on this problem. Morphometric data on S. sarda from North America, the Mediterranean, and the Gulf of Guinea are given in Table 6.

Demir (1964) presented meristic data on $S$. sarda from Turkish waters. He found that fin ray counts in the ventral and caudal fins did not vary. However, there were variations in the number of rays in the other fins. He also found variation in the number of vertebrae, gill rakers, and teeth. He computed the mean, standard deviation, 
Table 2.-Common and vernacular names of Sarda spp.

\begin{tabular}{|c|c|c|c|}
\hline Species & Country & $\begin{array}{c}\text { Standard } \\
\text { common names }\end{array}$ & Vernacular names \\
\hline Sarda australis & Australia & Australian bonito & Horse mackerel, little bonito \\
\hline \multirow[t]{3}{*}{ Sarda chiliensis } & United States & Pacific bonito & \\
\hline & Chile & Bonito & \\
\hline & Peru & Bonito & \\
\hline \multirow[t]{8}{*}{ Sarda orientalis } & Australia (Western) & Oriental bonito & \\
\hline & India & Oriental bonito & Vari choora (Malayalam) \\
\hline & Mauritius-Seychelles & & Brasse-a-dents (Creole name) \\
\hline & Somali & & Sinufa \\
\hline & $\begin{array}{l}\text { South Africa, } \\
\text { Republic of }\end{array}$ & Bonito & \\
\hline & Japan & Hagatsuo & $\begin{array}{l}\text { Kitsunegatsuo, Hohzan, } \\
\text { Sujigatsuo, Sabagatsuo, } \\
\text { Shimagatsuo, Tozan }\end{array}$ \\
\hline & United States & Bonito & \\
\hline & Sri Lanka (Ceylon) & & Thora-baleya \\
\hline \multirow[t]{27}{*}{ Sarda sarda } & Albania & Palamiti & \\
\hline & Algeria & Bonite & $\begin{array}{l}\text { Bonito, Bonite a dos raye } \\
\text { Palamita, Rsela }\end{array}$ \\
\hline & Bulgaria & Palamud, Turuk & Lakerda \\
\hline & Canary Islands & Bonito & Bonite \\
\hline & Denmark & Rygstribet Pelamide & \\
\hline & France & Bonite a dos raye & $\begin{array}{l}\text { Pelamide commun, Pelamide, } \\
\text { Conite, Pelamido, Pelamida, } \\
\text { Palamida, Boniton, Bonicou, } \\
\text { Bonnicou, Boussicou, Boussicon }\end{array}$ \\
\hline & Greece & Palamida, Toriki & $\begin{array}{l}\text { Pelamyda, Doriki, Touliki, } \\
\text { Ternata, Koini }\end{array}$ \\
\hline & Germany & Pelamide & $\begin{array}{l}\text { Bonite, Unechter bonito, } \\
\text { Mittellandischen bonite, } \\
\text { Rygstribed pelamite }\end{array}$ \\
\hline & Israel & Sarda & \\
\hline & Italy & Palamita & $\begin{array}{l}\text { Palamita sarda, Pelamida, } \\
\text { Palamide, Palamida, Palamita, } \\
\text { Palamito, Palamitu maiaticus, } \\
\text { Palametto, Pilamitu, Palamia, } \\
\text { Paamie, Pirantuni, Pisantuni, } \\
\text { Tombarello, Parantuni, Strombo } \\
\text { Strumbo, Scurma, Sangulu, } \\
\text { Sgamiru, Sgonfietto, Cuvarita, } \\
\text { Cavaritu imperiali, Bonnicou, } \\
\text { Tunnachiu }\end{array}$ \\
\hline & Libya & Balamit & Blamto \\
\hline & Madeira Islands & Cerda & \\
\hline & Malta & Palamit & $\begin{array}{l}\text { Plamtu, Palamita, Plamitu, } \\
\text { Palamia }\end{array}$ \\
\hline & Monaco & Palamida & Piramida, Paramida \\
\hline & Morocco & Cerda, Bonito & \\
\hline & Portugal & Bonito, Serra & \\
\hline & Rumania & Pelamida & Lacherda \\
\hline & Spain & Bonito & Bonitol, Bonitu, Cerda \\
\hline & South Africa & Bonito & Katankel, Sarrajoa \\
\hline & Sweden & Pelamide & Rygstrimmig pelamid \\
\hline & Syria & Palamet & \\
\hline & Tunisia & Palamid & $\begin{array}{l}\text { Pelamid, Balamit, Toumbrel, } \\
\text { Rsela }\end{array}$ \\
\hline & Turkey & Palamut, Torik & \\
\hline & United Kingdom & Pelamid & $\begin{array}{l}\text { Belted bonito, Stripe-backed } \\
\text { pelamis }\end{array}$ \\
\hline & U.S.S.R. & Pelamida & Lacherda \\
\hline & United States & Common Bonito & $\begin{array}{l}\text { Atlantic bonito, Bonito, } \\
\text { Boston mackerel, Bone jack, } \\
\text { Bloater, Skipjack }\end{array}$ \\
\hline & Yugoslavia & Polanda & $\begin{array}{l}\text { Polandra, Palovnic, Pastrica, } \\
\text { Sarica, Sargasto, Tombarel, } \\
\text { Trup lacherda }\end{array}$ \\
\hline
\end{tabular}


Table 3.-Morphometric characters of Sarda australis. Upper set of numbers are measurements expressed in thousandths of fork length, lower set as thousandths of head length. (From Collette and Chao 1975, table 18.)

\begin{tabular}{cccc}
\hline Character & Range & $\bar{x}$ & $N$ \\
\hline Fork length $(\mathbf{m m})$ & $195-526$ & 349 & 2
\end{tabular}

Fork length

$\begin{array}{lcrl}\text { Snouth - A } & 662-698 & 674 & 20 \\ \text { Snout - 2D } & 581-605 & 586 & 20 \\ \text { Snout - 1D } & 251-276 & 263 & 20 \\ \text { Snout - } P_{2} & 281-312 & 296 & 20 \\ \text { Snout - } P_{1} & 258-281 & 267 & 20 \\ P_{1}-P_{2} & 104-125 & 116 & 19 \\ \text { Head length } & 259-279 & 267 & 20 \\ \text { Max. body depth } & 221-240 & 231 & 16 \\ \text { Max. body wicth } & 127-169 & 141 & 17 \\ P_{1} \text { length } & 112-135 & 121 & 19 \\ P_{2} \text { length } & 76-118 & 85 & 20 \\ P_{2} \text { insertion - vent } & 340-393 & 374 & 18 \\ P_{2} \text { tip - vent } & 260-311 & 290 & 18 \\ \text { Base 1D } & 315-343 & 326 & 20 \\ \text { Height 2D } & 77-95 & 86 & 19 \\ \text { Base 2D } & 88-118 & 103 & 20 \\ \text { Height anal } & 72-92 & 81 & 20 \\ \text { Base anal } & 48-88 & 78 & 20 \\ \text { Caudal spread } & 238-277 & 259 & 11 \\ \text { Snout (fleshy) } & 88-103 & 96 & 20 \\ \text { Snout (bony) } & 76-88 & 81 & 20 \\ \text { Maxilla length } & 131-150 & 139 & 20 \\ \text { Post orbital } & 120-136 & 130 & 20 \\ \text { Orbit (fleshy) } & 32-41 & 37 & 19 \\ \text { Orbit (bony) } & 56-84 & 66 & 20 \\ \text { Interorbital width } & 58-72 & 66 & 19\end{array}$

Head length

\begin{tabular}{llll} 
Snout (fleshy) & $342-381$ & 361 & 20 \\
Snout (bony) & $291-324$ & 305 & 20 \\
Maxilla length & $503-539$ & 518 & 20 \\
Post orbital & $478-508$ & 492 & 20 \\
Orbit (fleshy) & $134-148$ & 137 & 19 \\
Orbit (bony) & $231-287$ & 246 & 20 \\
Interorbital width & $226-266$ & 249 & 19 \\
\hline
\end{tabular}

and standard error of the mean for each meristic character with varying counts.

\subsection{Protein specificity}

See also section 4.14 .

Cushing (1964) reported on the use of lectin in the investigation of antigens of tunas and other species. As Cushing pointed out, lectins are not antibodies per se but proteins possessing antibodylike properties. The most well known source of lectin is the seeds of plants of a variety of species. Cushing cited unpublished results of experiments which showed that lectins can be useful reagents in detecting antigens in fishes. The lectin obtained from seeds of a plant, Dolichos bifloris, that is routinely used to distinguish the human $\mathrm{A}_{1}$ subtype was used to show that a significant difference exists between the frequencies of positive fish occurring in samples of $S$. chiliensis of larger and smaller sizes. The cause of this difference has not been determined.
Barrett and Williams (1965) determined the blood hemoglobin level of nine specimens of $S$. chiliensis. The hemoglobin level ranged from 11.2 to $15.3 \mathrm{~g} / 100 \mathrm{ml}$ and averaged $12.9 \mathrm{~g} / 100 \mathrm{ml}$.

\section{DISTRIBUTION}

\subsection{Total area}

The distribution of the four species of Sarda as given below and in Figure 2 was adapted from Collette and Chao (1975). The geographic classification and codes given by Rosa (1965) were followed.

Sarda australis

ISEW (Indo-Pacific, central)

610 Australia. 614 Victoria; 615 New South Wales; 616 Queensland; 617 Tasmania; 618 Norfolk Island.

Sarda australis is known only from the east coast of Australia and Norfolk Island. Off the east Australia coast, it is common from about the Capricorns (Queensland) to Sydney or even Gabo Island (Whitley 1964). The westernmost record for the species is from Port Fairy, Victoria (Serventy 1941b).

\section{Sarda chiliensis}

INE (Pacific, NE)

ISE (Pacific, SE)

200 North America. 212 British Columbia; 220 Alaska; 231 Washington; 232 California.

300 Latin America. 311 Mexico; 342 Peru; 343 Chile.

This species is found only in the eastern Pacific, where it is separated geographically into north and south temperate populations. The usual range of the northeast population is from about Point Conception, Calif., to Magdalena Bay, Baja California. There is a record of this species from Socorro Island in the Revilla Gigedos. It is uncommon north of Point Conception but it has been recorded from off the Farallon Islands and Eureka, Calif.; off Puget Sound, Wash.; off the east coast of Vancouver Island, B.C., Canada; and in coastal Alaska in Clarence Strait northwest of Ketchikan and off the Copper River.

The range of the southeastern population is along the coast of South America from Mancora, Peru, in the north to Valdivia, Chile, in the south.

\section{Sarda orientalis}

ISE (Pacific, SE)

ISEW (Indo-Pacific, central)

ISW (Indian Ocean)

100 Africa. 154 South Africa; 156 Malagasy Republic. 
Table 4.-Comparison of morphometric characters in two populations of Sarda chiliensis, northeast Pacific (S. c. lineolata) and southeast Pacific (S. c. chiliensis). Upper set of numbers are measurements expressed as thousandths of fork length, lower set as thousandths of head length. (From Collette and Chao 1975, table 19.)

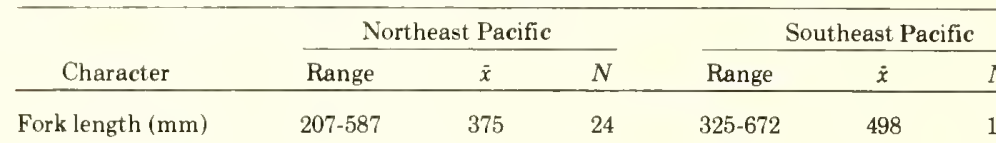

Fork length

$\begin{array}{lrrrrrr}\text { Snout - A } & 642-674 & 656 & 23 & 631-672 & 654 & 18 \\ \text { Snout - 2D } & 553-595 & 573 & 24 & 551-585 & 569 & 18 \\ \text { Snout - 1D } & 243-281 & 269 & 24 & 268-290 & 279 & 18 \\ \text { Snout - } \mathrm{P}_{2} & 275-318 & 295 & 24 & 280-323 & 303 & 18 \\ \text { Snout - }{ }_{1} & 247-279 & 266 & 24 & 260-300 & 275 & 18 \\ \mathrm{P}_{1}-\mathrm{P}_{2} & 106-121 & 112 & 21 & 105-131 & 118 & 16 \\ \text { Head length } & 248-275 & 263 & 24 & 259-292 & 272 & 18 \\ \text { Max. body depth } & 179-232 & 210 & 19 & 177-230 & 210 & 13 \\ \text { Max. body width } & 98-167 & 131 & 22 & 116-154 & 134 & 10 \\ \mathrm{P}_{1} \text { length } & 99-132 & 116 & 24 & 125-152 & 138 & 18 \\ \mathrm{P}_{2} \text { length } & 65-87 & 78 & 24 & 65-91 & 84 & 18 \\ \mathrm{P}_{2} \text { insertion - vent } & 329-367 & 353 & 24 & 327-368 & 346 & 16 \\ \mathrm{P}_{2} \text { tip - vent } & 248-331 & 276 & 24 & 237-352 & 269 & 17 \\ \text { Base 1D } & 278-314 & 297 & 24 & 267-303 & 286 & 16 \\ \text { Height 2D } & 64-98 & 83 & 23 & 82-116 & 97 & 17 \\ \text { Base 2D } & 71-115 & 93 & 23 & 80-109 & 94 & 18 \\ \text { Height anal } & 58-89 & 74 & 23 & 77-107 & 92 & 18 \\ \text { Base anal } & 61-84 & 71 & 24 & 61-88 & 74 & 18 \\ \text { Caudal spread } & 196-300 & 234 & 20 & 228-289 & 258 & 11 \\ \text { Snout (fleshy) } & 87-119 & 94 & 24 & 86-102 & 95 & 18 \\ \text { Snout (bony) } & 71-83 & 78 & 24 & 75-89 & 81 & 18 \\ \text { Maxilla length } & 115-136 & 126 & 24 & 121-143 & 130 & 18 \\ \text { Post orbital } & 125-144 & 139 & 21 & 131-150 & 142 & 16 \\ \text { Orbit (fleshy) } & 25-44 & 31 & 24 & 27-36 & 31 & 18 \\ \text { Orbit (bony) } & 47-63 & 57 & 22 & 47-63 & 56 & 18 \\ \text { Interorbital width } & 57-69 & 63 & 24 & 62-82 & 70 & 18\end{array}$

Head length

\begin{tabular}{lllllll} 
Snout (fleshy) & $339-368$ & 353 & 23 & $331-363$ & 348 & 18 \\
Snout (bony) & $283-308$ & 297 & 24 & $279-329$ & 299 & 18 \\
Maxilla length & $460-503$ & 481 & 24 & $463-489$ & 477 & 18 \\
Post orbital & $499-548$ & 526 & 21 & $504-544$ & 523 & 16 \\
Orbit (fleshy) & $102-168$ & 119 & 24 & $102-141$ & 115 & 18 \\
Orbit (bony) & $190-238$ & 218 & 22 & $174-229$ & 205 & 18 \\
Interorbital width & $213-278$ & 239 & 24 & $233-302$ & 257 & 18 \\
\hline
\end{tabular}

300 Latin America. 311 Mexico; 314 Costa Rica; 315 Panama; 341 Ecuador (Galápagos Islands); 342 Peru.

400 Asia. 423 India; 424 Sri Lanka; 437 Phillippines; 438 Khmer Republic (Cambodia); 451 Japan.

600 Oceania. 612 Western Australia; 660 U.S.A. (Hawaii).

This bonito occurs in widely scattered locations in the Indo-Pacific and Pacific. There is a population of $S$. orientalis in the tropical eastern Pacific that is confined to the coastal areas between the tip of Baja California, Mexico, and Ecuador and around the Galápagos Islands. It occurs in Hawaii but is not common there. In Japan, the species occurs along both coasts of Honshu and is most abundant along the coasts of Kyushu. The species has been recorded from the coast of China and also from the Philippines.

In the Indian Ocean $S$. orientalis has been recorded from southwest Australia, along both coasts of India and from Sri Lanka, from Muscat at the entrance to the Per- sian Gulf, in the Seychelles Islands and Aldabra Island, and along the coast of Natal, South Africa, south to Durban. It has also been recorded from Eilat at the northern end of the Gulf of Aqaba in the Red Sea.

\section{Sarda sarda}

ANW (Atlantic, NW)

ASW (Atlantic, SW)

ANE (Atlantic, NE)

ASE (Atlantic, SE including Bay of Biscay,

Mediterranean Sea, Sea of Marmara, Black Sea)

100 Africa. 110 northwestern area; 111 Tunisia; 112 Algeria; 113 Morocco; 114 Canary Islands; 115 former Spanish Sahara; 140 western central area; 141 Islamic Republic of Mauritania; Republic of Senegal, Republic of Guinea; 142 Cape Verde Islands; 144 Ghana; 151 Angola; 152 South-West Africa; 154 Republic of South Africa. 
Table 5. - Comparison of morphometric characters in populations of Sarda orientalis from Japan and the eastern tropical Pacific. Upper set of numbers are measurements expressed as thousandths of fork length, lower set as thousandths of head length. (From Collette and Chao 1975, table 20.)

\begin{tabular}{|c|c|c|c|c|c|c|}
\hline \multirow[b]{2}{*}{ Character } & \multicolumn{3}{|c|}{ Japan } & \multicolumn{3}{|c|}{ East tropical Pacific } \\
\hline & Range & $\vec{x}$ & $N$ & Range & $\bar{x}$ & $N$ \\
\hline Fork length (mm) & $342-560$ & 432 & 7 & $354-613$ & 472 & 10 \\
\hline
\end{tabular}

$\begin{array}{lr}\text { Snout - A } & 674-703 \\ \text { Snout - 2D } & 596-614 \\ \text { Snout - 1D } & 273-308 \\ \text { Snout }-\mathrm{P}_{2} & 293-316 \\ \text { Snout }-\mathrm{P}_{1} & 272-292 \\ \mathrm{P}_{1}-\mathrm{P}_{2} & 109-118 \\ \text { Head length } & 268-286 \\ \text { Max. body depth } & 221-244 \\ \text { Max. body width } & 143-151 \\ \mathrm{P}_{1} \text { length } & 104-125 \\ \mathrm{P}_{2} \text { length } & 70-78 \\ \mathrm{P}_{2} \text { insertion - vent } & 374-419 \\ \mathrm{P}_{2} \text { tip - vent } & 305-322 \\ \text { Base 1D } & 285-327 \\ \text { Height 2D } & 75-82 \\ \text { Base 2D } & 85-111 \\ \text { Height anal } & 61-85 \\ \text { Base anal } & 66-78 \\ \text { Caudal spread } & 168-234 \\ \text { Snout (fleshy) } & 86-103 \\ \text { Snout (bony) } & 80-97 \\ \text { Maxilla length } & 141-149 \\ \text { Post orbital } & 128-147 \\ \text { Orbit (fleshy) } & 32-60 \\ \text { Orbit (bony) } & 29-65 \\ \text { Interorbital width } & 67-73 \\ & \\ & \end{array}$

Fork length

$\begin{array}{rrrrr}694 & 5 & 662-703 & 678 & 10 \\ 606 & 5 & 569-596 & 582 & 10 \\ 286 & 7 & 274-311 & 288 & 10 \\ 303 & 5 & 299-321 & 310 & 10 \\ 281 & 7 & 277-299 & 290 & 10 \\ 113 & 5 & 105-118 & 114 & 10 \\ 278 & 7 & 266-294 & 284 & 10 \\ 234 & 4 & 193-236 & 213 & 10 \\ 146 & 4 & 127-153 & 144 & 10 \\ 115 & 7 & 119-134 & 127 & 10 \\ 76 & 5 & 81-91 & 86 & 10 \\ 392 & 7 & 353-384 & 367 & 10 \\ 311 & 3 & 265-302 & 280 & 10 \\ 306 & 7 & 282-302 & 292 & 10 \\ 78 & 7 & 89-101 & 94 & 8 \\ 93 & 7 & 88-107 & 95 & 9 \\ 73 & 7 & 84-97 & 89 & 8 \\ 73 & 7 & 73-83 & 79 & 9 \\ 214 & 4 & 192-259 & 236 & 5 \\ 96 & 7 & 98-105 & 101 & 10 \\ 86 & 7 & 83-91 & 86 & 10 \\ 145 & 6 & 146-156 & 150 & 10 \\ 139 & 5 & 141-151 & 146 & 10 \\ 42 & 7 & 34-40 & 37 & 10 \\ 56 & 7 & 60-68 & 64 & 10 \\ 71 & 6 & 65-79 & 71 & 10\end{array}$

\begin{tabular}{lllllll} 
Snout (fleshy) & $306-368$ & 344 & 7 & $348-369$ & 357 & 10 \\
Snout (bony) & $288-344$ & 308 & 7 & $291-317$ & 303 & 10 \\
Maxilla length & $510-529$ & 522 & 6 & $512-557$ & 528 & 10 \\
Post orbital & $476-525$ & 503 & 5 & $494-553$ & 512 & 10 \\
Orbit (fleshy) & $102-152$ & 136 & 7 & $120-147$ & 130 & 10 \\
Orbit (bony) & $210-234$ & 220 & 7 & $210-238$ & 226 & 10 \\
Interorbital width & $251-263$ & 256 & 6 & $230-283$ & 251 & 10 \\
\hline
\end{tabular}

200 North America. 217 Nova Scotia; 235 Southern States; 238 Southern Atlantic States.

300 Latin America. 311 Mexico; 321 Trinidad; 331

Colombia; 332 Venezuela; 351 Brazil; 353 Argentina.

400 Asia. 411 Lebanon; 413 Israel.

500 Europe. 510 Scandinavia; 511 Denmark; 514 Norway; 521 Netherlands; 524 France; 531 Ireland; 534 Scotland; 541 Azores, Madeira; 542 Spain, Balearic Islands; 543 Italy; 553 Greece; 555 Socialist Republic of Romania; 556 Turkey.

700 Union of Soviet Socialist Republic. 710 Crimea.

This bonito is found on both sides of the tropical and temperate Atlantic Ocean, in the Gulf of Mexico, and in the Mediterranean and Black Seas. In the western Atlantic off the east coast of the United States its usual northern limit is Cape Ann, Mass. However, $S$. sarda has been recorded from Casco Bay, Maine, and from several localities along the outer coast of Nova Scotia. It occurs off Florida but is uncommon off Miami and the Florida Keys.

Off the Atlantic coast of South America the species is recorded from Colombia and Venezuela and from about Rio de Janeiro, Brazil, to Buenos Aires, Argentina.

\section{Biogeographical and natural characteristics of areas}

No detailed description of the habitat of the four species of Sarda will be presented here. From all indications the species of Sarda are inhabitants of the coastal or the pelagic neritic province. Sverdrup et al. (1942) set the vertical border separating the neritic from the oceanic province at the edge of the continental shelf. Thus the neritic zone would include all waters of depths $<200 \mathrm{~m}$ and accordingly may extend far seaward where the continental shelf is wide or may extend only a short distance where the shelf is narrow. "The chemical constituents of the sea water in the neritic province are more 
Table 6.-Comparison of morphometric characters in populations of Sarda sarda from North America, the Mediterranean Sea, and the Gulf of Guinea. Upper set of numbers are measurements expressed as thousandths of fork length, lower set as thousandths of head length. (From Collette and Chao 1975, table 21.)

\begin{tabular}{|c|c|c|c|c|c|c|c|c|c|}
\hline \multirow[b]{2}{*}{ Character } & \multicolumn{3}{|c|}{ North America } & \multicolumn{3}{|c|}{ Mediterranean } & \multicolumn{3}{|c|}{ Gulf of Guinea } \\
\hline & Range & $\bar{x}$ & $N$ & Range & $\bar{x}$ & $N$ & Range & $\bar{x}$ & $N$ \\
\hline Fork length (mm) & $228-500$ & 362 & 17 & $260-504$ & 376 & 7 & $305-443$ & 379 & 9 \\
\hline
\end{tabular}

$\begin{array}{lrrrrrrrrr}\text { Snout - A } & 646-690 & 668 & 13 & 641-685 & 660 & 7 & 648-666 & 657 & 9 \\ \text { Snout - 2D } & 570-594 & 582 & 13 & 563-593 & 579 & 7 & 570-585 & 578 & 9 \\ \text { Snout - 1D } & 262-275 & 270 & 13 & 257-284 & 266 & 7 & 262-306 & 298 & 9 \\ \text { Snout - } \mathrm{P}_{2} & 286-304 & 296 & 12 & 280-302 & 288 & 6 & 267-284 & 275 & 9 \\ \text { Snout - } \mathrm{P}_{1} & 259-284 & 269 & 13 & 255-274 & 263 & 7 & 253-273 & 267 & 9 \\ \mathrm{P}_{1}-\mathrm{P}_{2} & 105-118 & 111 & 12 & 94-114 & 104 & 7 & 107-118 & 111 & 8 \\ \text { Head length } & 256-272 & 264 & 13 & 251-268 & 259 & 7 & 253-278 & 271 & 9 \\ \text { Max. body depth } & 200-224 & 214 & 8 & 197-216 & 205 & 5 & 195-228 & 217 & 8 \\ \text { Max. body width } & 96-171 & 135 & 10 & 115-148 & 131 & 6 & & & \\ \mathrm{P}_{1} \text { length } & 96-138 & 115 & 13 & 105-127 & 116 & 6 & 120-136 & 130 & 9 \\ \mathrm{P}_{2} \text { length } & 73-84 & 79 & 12 & 76-86 & 82 & 7 & 77-87 & 83 & 9 \\ \mathrm{P}_{2} \text { insertion - vent } & 348-403 & 366 & 13 & 356-379 & 370 & 7 & 341-388 & 357 & 9 \\ \mathrm{P}_{2} \text { tip - vent } & 269-302 & 282 & 12 & 269-297 & 285 & 7 & 252-293 & 266 & 9 \\ \text { Base 1D } & 291-330 & 311 & 13 & 301-323 & 311 & 7 & 298-323 & 311 & 9 \\ \text { Height 2D } & 68-90 & 80 & 10 & 85-117 & 95 & 5 & 81-99 & 91 & 9 \\ \text { Base 2D } & 85-113 & 96 & 13 & 93-112 & 104 & 5 & 92-112 & 107 & 9 \\ \text { Height anal } & 68-98 & 77 & 11 & 68-85 & 79 & 6 & 77-91 & 85 & 9 \\ \text { Base anal } & 63-86 & 73 & 13 & 69-90 & 78 & 7 & 66-89 & 80 & 9 \\ \text { Caudal spread } & 204-235 & 222 & 5 & 226-270 & 247 & 4 & 223-289 & 253 & 3 \\ \text { Snout (fleshy) } & 76-100 & 94 & 13 & 88-98 & 93 & 7 & 88-101 & 96 & 9 \\ \text { Snout (bony) } & 78-93 & 82 & 13 & 74-83 & 78 & 7 & 75-85 & 82 & 9 \\ \text { Maxilla length } & 131-141 & 136 & 13 & 127-136 & 131 & 7 & 125-145 & 138 & 9 \\ \text { Post orbital } & 130-142 & 136 & 11 & 126-136 & 132 & 7 & 133-144 & 138 & 9 \\ \text { Orbit (fleshy) } & 27-40 & 32 & 17 & 27-34 & 31 & 7 & 31-36 & 34 & 9 \\ \text { Orbit (bony) } & 35-64 & 57 & 13 & 53-62 & 57 & 6 & 53-64 & 60 & 9 \\ \text { Interorbital width } & 59-73 & 64 & 13 & 59-64 & 62 & 7 & 58-65 & 63 & 9\end{array}$

$\begin{array}{llllllllll}\text { Interorbital width } & 59-73 & 64 & 13 & 59-64 & 62 & 7 & 58-65 & 63 & 9\end{array}$

\begin{tabular}{llllllllll} 
Snout (fleshy) & $354-374$ & 360 & 17 & $346-367$ & 358 & 7 & $346-366$ & 353 & 9 \\
Snout (bony) & $289-342$ & 309 & 13 & $289-312$ & 303 & 7 & $293-308$ & 301 & 9 \\
Maxilla & $503-529$ & 514 & 13 & $497-511$ & 505 & 7 & $494-523$ & 509 & 9 \\
Post orbital & $494-541$ & 516 & 11 & $503-521$ & 511 & 7 & $489-519$ & 506 & 9 \\
Orbit (fleshy) & $100-149$ & 121 & 17 & $104-133$ & 118 & 7 & $116-132$ & 122 & 9 \\
Orbit (bony) & $203-248$ & 222 & 16 & $210-232$ & 220 & 6 & $204-228$ & 220 & 9 \\
Interorbital width & $216-275$ & 242 & 13 & $231-245$ & 238 & 7 & $212-245$ & 231 & 9 \\
\hline
\end{tabular}

variable than in the oceanic. Salinities are usually lower, sometimes markedly, and undergo seasonal or sporadic fluctuations such that many of the inhabitants are more or less euryhaline in nature - that is, able to endure wide ranges of salinity." (Sverdrup et al. 1942.)

Laevastu and Rosa (1963) determined the distribution of various species of tunas and the temperature range in which the species were found. For the species of bonitos they gave a general temperature range of $12^{\circ}$ $25^{\circ} \mathrm{C}$ and the temperature range of the fisheries for bonitos as $15^{\circ}-22^{\circ} \mathrm{C}$.

\subsection{Differential distribution}

2.21 Spawn, larvae, and juveniles

\section{Sarda australis}

There is no information on the distribution of fertil- ized eggs of $S$. australis. The capture of the larvae and juveniles also has yet to be recorded in the literature.

\section{Sarda chiliensis}

The distribution of the fertilized eggs of $S$. chiliensis in the eastern Pacific is not well defined. Barnhart (1927) collected bonito eggs in a plankton net off La Jolla, Calif. Orton (1953b) described the early embryonic stage of $\mathrm{Pa}$ cific bonito but gave no capture locality for her samples. Sokolovskii (1971) made a more detailed study of the distribution of fertilized eggs of the Pacific bonito off Baja California (Fig. 3). As noted by Sokolovskii, S. chiliensis lineolata in the spring of 1966 spawned mostly in the shallow waters of the coastal zone. He found fewer fertilized eggs outside the $200 \mathrm{~m}$ isobath. He also determined that the eggs are found only at the surface, for no eggs were collected in vertical plankton hauls.

Records of capture of juvenile S. chiliensis (Table 7) 


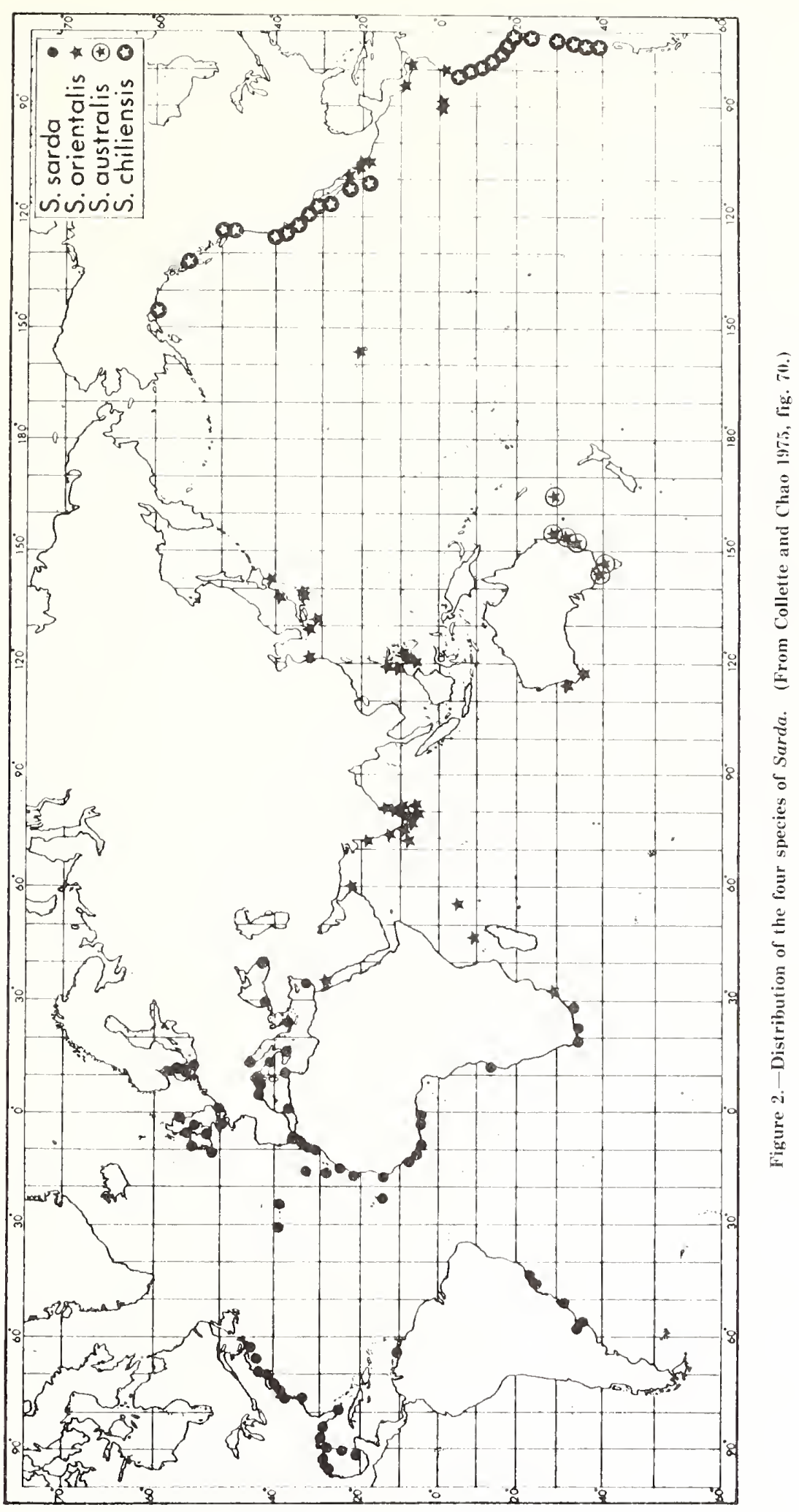




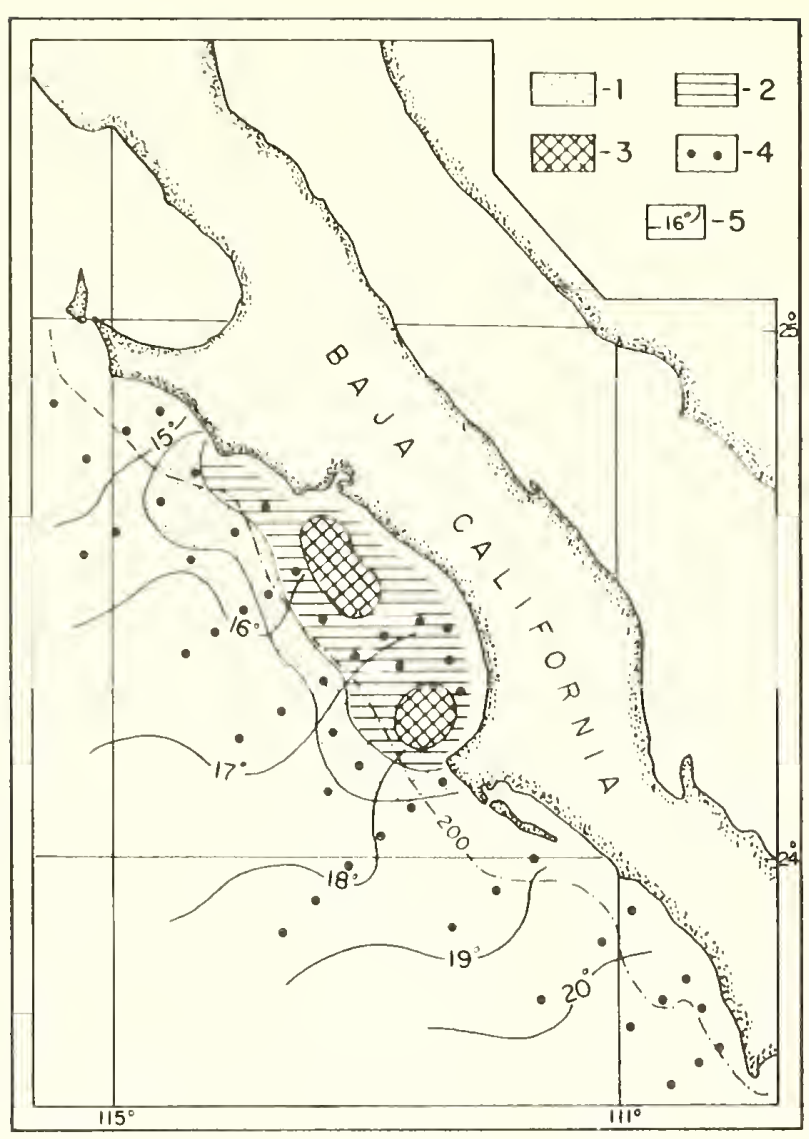

Figure 3.-Distribution of the fertilized eggs of Sarda chiliensis lineolata off Baja California in the spring of 1966 , based on tows with the ichthyoplankton net. 1 -from 1 to $50 ; 2$-from 51 to $500 ; 3$-more than 500 in one tow of the egg net; 4-ichthyoplanktonic stations; 5-isotherms. (From Sokolovskii 1971.)

include two larvae 2.9 and $3.5 \mathrm{~mm}$ long; Klawe (1961b) could not determine whether they were $S$. chiliensis or $S$. orientalis. Other than the prelarval stages which Barnhart (1927) and Orton (1953a, 1953b) reported, and the two larvae recorded by Klawe, the only other larvae of Sarda reported from the eastern Pacific are those by Sokolovskii (1971). Sokolovskii reported the capture of six larvae ranging from 7 to $13.8 \mathrm{~mm}$ at an ichthyoplankton station in the waters off Baja California. It can be seen from Table 7 that juvenile $S$. chiliensis in the Northern Hemisphere have been found off Baja California between lat. $22^{\circ}$ and $26^{\circ} \mathrm{N}$. In the Southern Hemisphere they have been found along the coast of Chile and Peru between lat. $13^{\circ}$ and $25^{\circ} \mathrm{S}$. Vildoso (1966) sampled preadult $S$. c. chiliensis from the Peruvian fishery ranging upward from $20 \mathrm{~cm}$, and Barrett (1971) reported bonito of about $15 \mathrm{~cm}$ taken with anchovy catches at Arica, Chile. In southern California, preadult S. c. lineolata $15.2-25.4 \mathrm{~cm}$ (6-10 in) are first seen by the bait fishermen in the early summer (Frey 1971).

\section{Sarda orientalis}

There is hardly any information in the literature on the distribution of the fertilized eggs of $S$. orientalis. Mito (1961) gave generalized descriptions of fertilized eggs of the species in what he termed the Scombrina, including S. orientalis. However, Mito gave no capture locality for his samples. Except for this fragmentary bit of information on the planktonic fertilized eggs of $S$. orientalis off Japan, there is nothing on the distribution of their eggs in the other areas of the Pacific and Indo-Pacific where this species occurs.

Records of larval S. orientalis are few. Gorbunova (1963) recorded the capture of a larva $11.56 \mathrm{~mm}$ long from off the northwest coast of Australia in the Indian Ocean. Elsewhere in the Indian Ocean, Jones (1960) reported specimens $80,89,174$, and $262 \mathrm{~mm}$ in total length from Vizhingam on the west coast of India. In the Pacific Ocean, juveniles ranging in length between 75 and 100 $\mathrm{mm}$ are reportedly caught in waters adjacent to southern Kyushu (Yabe et al. 1953), and Kishinouye (1923) reported a specimen $170 \mathrm{~mm}$ taken off Wakayama Prefecture, Japan. Juveniles from the stomachs of predators have been recorded from Hawaii (Honolulu Laboratory, Southwest Fisheries Center, unpubl. data.)

Yabe et al. (1953) reported that $75-100 \mathrm{~mm}$ S. orientalis are caught in waters around southern Kyushu. They also reported on $S$. orientalis landed at the port of Aburatsu, Japan, ranging in size from 161 to $348 \mathrm{~mm}$. Preadult $S$. orientalis occasionally appear in large numbers in the Indian Ocean. Jones (1960) reported large catches of fish ranging in length from 160 to $200 \mathrm{~mm}$ off the west coast of India between Trivandrum and Cape Comorin. Gnanamuttu (1966) recorded the occurrence of S. orientalis ranging from 240 to $260 \mathrm{~mm}$ in total length off the northeast coast of India. In the waters around Sri Lanka the commercial fishery lands fish ranging upwards from $20 \mathrm{~cm}$ (Sivasubramaniam 1969).

\section{Sarda sarda}

The distribution of fertilized eggs of $S$. sarda has been studied in greater detail in the Black Sea and the Sea of Marmara. Mayorova and Tkacheva (1959) reported on the distribution of $S$. sarda eggs in the Black Sea in 1956 and 1957 (Fig. 4). They noted that in 1956 bonito eggs were found in great numbers in the surface layer, the maximum catch amounting to 12,000 eggs per " 10 -min catch," presumably made using a plankton net. At a depth of $5 \mathrm{~m}$ the number of eggs taken did not exceed 5,000 eggs/10-min tow. In 1957 the overall abundance of fertilized eggs was less than in 1956, and the vertical distribution was also different in that the $5 \mathrm{~m}$ depth produced more eggs than the surface layer. Demir (1963) noted that available data indicate that $S$. sarda eggs have been found everywhere in the Black Sea, the locations varying from year to year.

The fertilized eggs of $S$. sarda have also been found in the Sea of Marmara (Fig. 5) (Demir 1963). It can be seen from Figure 5 that in June and July of 1959 most of the fertilized eggs were found in the eastern portion of the Sea of Marmara. 
Table 7.- Records of capture of juvenile Sarda chiliensis from the eastern Pacific. (From Pinkas 1961, table 2; Klawe 1961b, table 2, 1962.)

\begin{tabular}{|c|c|c|c|c|c|}
\hline Date & General locality & Latitude & Longitude & $\begin{array}{l}\text { Method of } \\
\text { capture }\end{array}$ & $\begin{array}{l}\text { Size range } \\
\text { Fork length } \\
\quad(\mathrm{mm})\end{array}$ \\
\hline
\end{tabular}

Northern Hemisphere

\begin{tabular}{|c|c|c|}
\hline \multicolumn{2}{|c|}{ 17-18 May 1947} & Off La Jolla, Calif., United \\
\hline 5 Aug. & 1951 & $\begin{array}{l}100 \text { miles NW of Cape San Lazaro, } \\
\text { Baja Calif., Mexico }\end{array}$ \\
\hline 5 Aug. & 1951 & Off Baja Calif., Mexico \\
\hline 12 Aug. & 1951 & $\begin{array}{l}\text { Off Ballenas Bay, Baja Calif., } \\
\text { Mexico }\end{array}$ \\
\hline 15 July & 1953 & $\begin{array}{l}\text { South of Cape San Lazaro, Baja } \\
\text { Calif., Mexico }\end{array}$ \\
\hline 18 July & 1953 & $\begin{array}{l}\text { Southwest of Cape San Lazaro, } \\
\text { Baja Calif., Mexico }\end{array}$ \\
\hline 11 Apr. & 1955 & $\begin{array}{l}\text { South of Cape San Lucas, Baja } \\
\text { Calif., Mexico }\end{array}$ \\
\hline 11 July & 1956 & $\begin{array}{l}\text { Southwest of Cape San Lucas, } \\
\text { Baja Calif., Mexico }\end{array}$ \\
\hline 12 July & 1956 & $\begin{array}{l}\text { Southwest of Cape San Lucas, } \\
\text { Baja Calif., Mexico }\end{array}$ \\
\hline 17 July & 1956 & $\begin{array}{l}\text { Southwest of Cape San Lucas, } \\
\text { Baja Calif., Mexico }\end{array}$ \\
\hline 5 Apr. & 1960 & Off Baja Calif., Mexico \\
\hline
\end{tabular}

\begin{tabular}{|c|c|c|c|}
\hline & & $\begin{array}{l}\text { Night light, } \\
\text { dip net }\end{array}$ & 一 \\
\hline $25^{\circ} 35^{\prime} \mathrm{N}$ & $113^{\circ} 56^{\prime} \mathrm{W}$ & $\begin{array}{l}\text { Night light, } \\
\text { dip net }\end{array}$ & 42 \\
\hline $25^{\circ} 35^{\prime} \mathrm{N}$ & $113^{\circ} 56^{\prime} \mathrm{W}$ & $\begin{array}{l}\text { Night light, } \\
\text { dip net }\end{array}$ & 42 \\
\hline $26^{\circ} 29.5^{\prime} \mathrm{N}$ & $133^{\circ} 29.2^{\prime} \mathrm{W}$ & Plankton net & $2.9,3.5$ \\
\hline $23^{\circ} 47^{\prime} \mathrm{N}$ & $112^{\circ} 25^{\prime} \mathrm{W}$ & $\begin{array}{l}\text { Night light, } \\
\text { dip net }\end{array}$ & $25-41$ \\
\hline $23^{\circ} 16^{\prime} \mathrm{N}$ & $112^{\circ} 45^{\prime} \mathrm{W}$ & $\begin{array}{l}\text { Night light, } \\
\text { dip net }\end{array}$ & $19-41$ \\
\hline $22^{\circ} 52.8^{\prime} \mathrm{N}$ & $109^{\circ} 53.7^{\prime} \mathrm{W}$ & $\begin{array}{l}\text { Night light, } \\
\text { dip net }\end{array}$ & 16.7 \\
\hline $23^{\circ} 35^{\prime} \mathrm{N}$ & $112^{\circ} 11^{\prime} \mathrm{W}$ & $\begin{array}{l}\text { Night light, } \\
\text { dip net }\end{array}$ & $33.0-33.5$ \\
\hline $22^{\circ} 20^{\prime} \mathrm{N}$ & $112^{\circ} 27^{\prime} \mathrm{W}$ & $\begin{array}{l}\text { Night light, } \\
\text { dip net }\end{array}$ & $24-48$ \\
\hline $22^{\circ} 47^{\prime} \mathrm{N}$ & $112^{\circ} 14^{\prime} \mathrm{W}$ & $\begin{array}{l}\text { Night light, } \\
\text { dip net }\end{array}$ & 54.5 \\
\hline $23^{\circ} 19^{\prime} \mathrm{N}$ & $110^{\circ} 22^{\prime} \mathrm{W}$ & $\begin{array}{l}\text { High speed } \\
\text { net }\end{array}$ & 92 \\
\hline
\end{tabular}

Southern Hemisphere

\begin{tabular}{|c|c|c|c|c|c|c|c|}
\hline 20 Feb. & 1951 & Off Pt. Lobos, Peru & & & $?$ & $125-130$ & 3 \\
\hline 3 Jan. & 1956 & Off Pt. Negra, Peru & & & Bait net & $143-164$ & 3 \\
\hline 10 Dec. & 1957 & Independencia Bay, Peru & $14^{\circ} 14^{\prime} \mathrm{S}$ & $76^{\circ} 12^{\prime} \mathrm{W}$ & Bait net & 128 & 1 \\
\hline 13 Dec. & 1957 & Off Ilo, Peru & $17^{\circ} 38^{\prime} \mathrm{S}$ & $71^{\circ} 23^{\prime} \mathrm{W}$ & Bait net & 121 & 1 \\
\hline 15 Dec. & 1957 & Off Ilo, Peru & $17^{\circ} 38^{\prime} \mathrm{S}$ & $71^{\circ} 18^{\prime} \mathrm{W}$ & Bait net & 200.9 & 1 \\
\hline 18 Dec. & 1957 & Off Ilo, Peru & & & Bait net & $70-135$ & 3 \\
\hline 21 Dec. & 1957 & South of Santa, Peru & $09^{\circ} 31^{\prime} \mathrm{S}$ & $78^{\circ} 26^{\prime} \mathrm{W}$ & Bait net & $38.0-51.0$ & 5 \\
\hline 31 Dec. & 1957 & Off Pt. Pichalo, Chile & $19^{\circ} 35^{\prime} \mathrm{S}$ & $70^{\circ} 16^{\prime} \mathrm{W}$ & $\begin{array}{l}\text { Night light, } \\
\text { dip net }\end{array}$ & 37 & 1 \\
\hline 1 Jan. & 1958 & Off Ilo, Peru & $17^{\circ} 47^{\prime} \mathrm{S}$ & $71^{\circ} 30^{\prime} \mathrm{W}$ & Bait net & 86.8 & 1 \\
\hline 3 Jan. & 1958 & Off Pt. Dos Reyes, Chile & $24^{\circ} 30^{\prime} \mathrm{S}$ & $70^{\circ} 49^{\prime} \mathrm{W}$ & $\begin{array}{l}\text { Night light, } \\
\text { dip net }\end{array}$ & 39 & 1 \\
\hline 3 Jan. & 1958 & Off Pt. Dos Reyes, Chile & $24^{\circ} 36^{\prime} \mathrm{S}$ & $71^{\circ} 01^{\prime} \mathrm{W}$ & $\begin{array}{l}\text { Night light, } \\
\text { dip net }\end{array}$ & $36-44$ & 3 \\
\hline 14 Jan. & 1958 & Southwest of Fraile Pt., Peru & $13^{\circ} 14.8^{\prime} \mathrm{S}$ & $77^{\circ} 55.5^{\prime} \mathrm{W}$ & $\begin{array}{l}\text { Night light, } \\
\text { dip net }\end{array}$ & 34 & 1 \\
\hline Feb. & 1958 & Off Chimbote, Peru & & & Bait net & $89-129$ & 3 \\
\hline 6 May & 1958 & Almejas Bay, Baja Calif., Mexico & & & Bait net & 103 & 1 \\
\hline 1 Feb. & 1959 & Sama Cove, Peru & & & Bait net & 111 & 1 \\
\hline 15 Mar. & 1959 & Off Ilo, Peru & & & $?$ & $135-160$ & 3 \\
\hline 16 Mar. & 1959 & Off Barranca, Peru & & & $?$ & 173,199 & 2 \\
\hline
\end{tabular}

${ }^{1}$ Identity uncertain.

It is of interest that very little is known of the distribution of fertilized S. sarda eggs in the Mediterranean Sea. Demir and Demir (1961) noted that planktonic fertilized eggs of $S$. sarda were unknown from the Mediterranean Sea. They pointed out that the eggs reported on by Sanzo (1932) were eggs that were extracted from a female gonad and artificially fertilized and reared. More recently, however, Duclerc et al. (1973) reported on the collection of fertilized $S$. sarda eggs near the Balearic Islands in the Mediterranean Sea. Thus, as far as can be determined from the literature, the distribution of ferti- lized eggs of bonito, is not very well defined in the Mediterranean Sea.

Except for the report of the collection of the fertilized eggs of $S$. sarda off the coast of Massachusetts by Sette (1943), nothing is known of their distribution in the Atlantic Ocean.

Mayorova and Tkacheva (1959) stated that S. sarda prelarvae and larvae occur in the same regions as the fertilized eggs in the Black Sea. Figure 4 shows that fertilized eggs of $S$. sarda are widely distributed in the Black Sea, thus indicating that larval bonito are also 

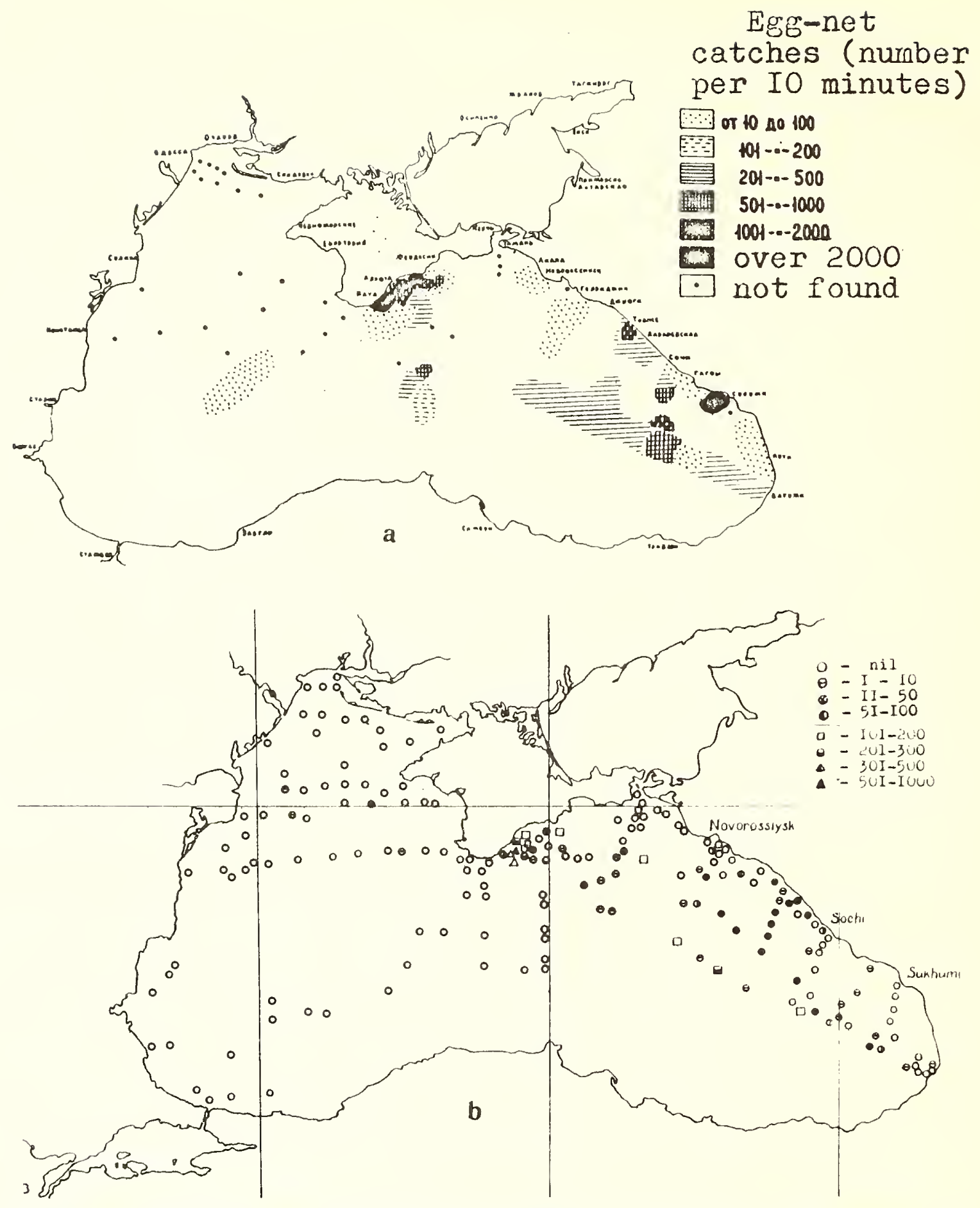

Figure 1.-Distribution of the fertilized eggs of Sarda sarda in the Black Sea, in June 1956 (a) and June 1957 (b). (From Mayorova and Tkacheva 1959 , figs. 1,2 .)

widely distributed. The larvae were more abundant at a depth of $5 \mathrm{~m}$ than at the surface. Mayorova and Tkacheva also noted that juvenile $S$. sarda $10-95 \mathrm{~mm}$ long were distributed over a vast area of the Black Sea in waters from 80 to 100 miles from the coast. In the Sea of Marmara, however, plankton tows did not reveal any $S$. sarda larvae although fertilized eggs in all stages of development were plentiful (Demir 1963).

Elsewhere, larvae of $S$. sarda have been reported from the Mediterranean Sea northwest of Oran by Ehrenbaum (1924) and in the Alboran and Mediterranean Seas by Buen $(1930,1932)$. More recently, freshly hatched 


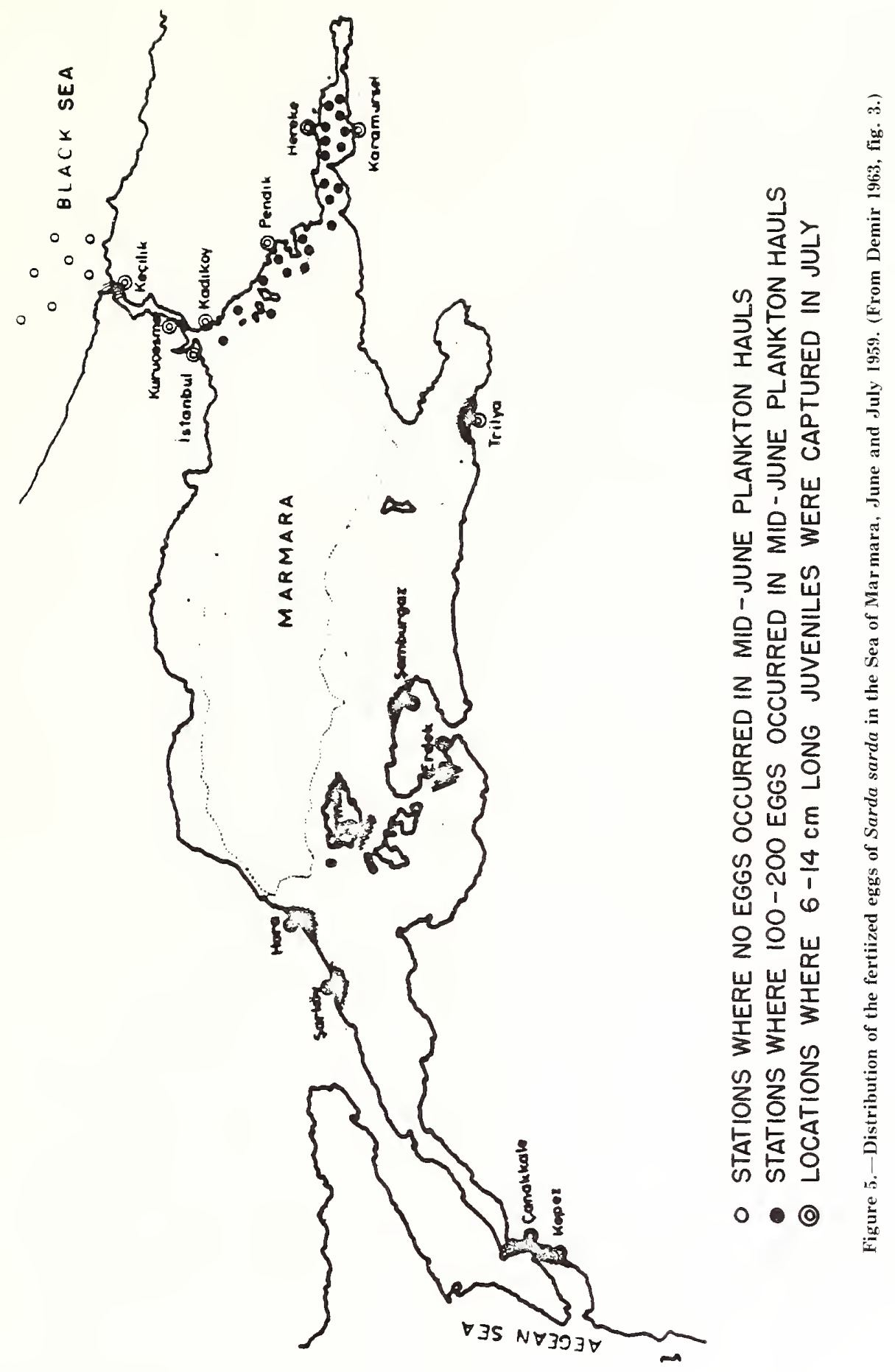


prelarvae were collected near the Balearic Islands by Duclerc et al. (1973). In the Atlantic Ocean, larvae have been found off Cuba (Gorbunova and Salabarría 1967), and a juvenile measuring $34 \mathrm{~mm}$ has been recorded off the South Carolina coast (Klawe 1961a). Two juvenile $S$. sarda 64 and $67 \mathrm{~mm}$ in total length were also captured in the Gulf of Mexico (Klawe and Shimada 1959).

Sarda sarda from 6 to $18 \mathrm{~cm}$ long are captured in varying numbers in the Dardanelles, the Bosporus, the Sea of Marmara, and the Black Sea nearly every year in JulyAugust (Demir 1963). The abundance of preadults in this size range apparently is a good indicator of the future abundance of fish $25-38 \mathrm{~cm}$ long which are the basis of an important Turkish fishery that takes place starting in September in the same areas. Preadults $8-12 \mathrm{~cm}$ long have been captured in large numbers in the Aegean Sea (Serbétis 1955), and Belloc (1954) discussed the occurrence of $S$. sarda 7.5-20 cm long caught in the Gulf of Naples and the Gulf of Catania and 15-25 cm long fish in the Bay of Biscay.

The capture of preadults $20-30 \mathrm{~cm}$ long has been reported from the Atlantic coast of France (De la Tourrasse 1957), and 25-35 cm fish have been taken commercially together with mackerel in the Miramichi estuary in the Gulf of St. Lawrence (McKenzie 1959). Klawe and Shimada (1959) reported the capture of two specimens 64 and $67 \mathrm{~mm}$ long in the Gulf of Mexico. Young S. sarda 12.7-15.2 cm (5-6 in) long have been taken off Orient, N.Y. (Nichols and Breder 1927).

\subsection{Adults}

\section{Sarda australis}

Information on the seasonal and annual variations in the occurrence of $S$. australis on the east coast of Australia is fragmentary. Serventy (1941b) stated that this species apparently is only a summer visitor to Victoria. Munro (1958) noted that $S$. australis was more plentiful north of Sydney in the winter; and according to Grant (1972), it commonly occurs in schools in inshore waters of Queensland, especially in winter. However, Marshall (1964) stated that $S$. australis is very common on the coasts of Queensland and New South Wales and is found in great schools throughout the year.

\section{Sarda chiliensis}

For the northeast population of $S$. chiliensis MacCall et al. (1976) suggested an uneven geographical distribution of various age groups. They noted that, roughly, older fish were more available offshore and around Mexico although large fish were also taken in the Santa Barbara, Calif., area in the fall.

As for the southeast population of S. chiliensis, Ancieta (1963) found that off the coast of Peru $82.2 \%$ of the total landings during 1951-60 were made in the central zone, from Chimbote to Pisco; $11.8 \%$ were made in the southern zone, from San Juan to Ilo; and 6\% were made in the northern zone, from Máncora to Salaverry. How- ever, Mejía et al. $(1971)^{3}$ noted that beginning in 1962 there has been a gradual overall decline in the annual Peruvian landings of $S$. c. chiliensis, most notably at the central zone port of Callao; in contrast the landings at the northern zone port of Paita increased somewhat.

Off the Chilean coast $S$. c. chiliensis are taken from the northern boundary of Chile to as far south as Talcahuano, but most are taken off the northern ports of Arica, Iquique, and Antofagasta, especially between Iquique and Mejillones (Barrett 1971). It was also seen that almost two-thirds of the annual Chilean landings of $S$. $c$. chiliensis are made in the last third of the year.

\section{Sarda orientalis}

Along the southwest coast of India, fully mature adult $S$. orientalis are found from May to September followed by the juveniles from October to November. Slight annual fluctuations in seasonal occurrence are also seen (Silas 1964).

Off the south coast of Sri Lanka (Ceylon), S. orientalis appears in the commercial catches throughout the year. Mature fish are taken off the south and southwest coasts primarily between September and February, and the juveniles appear off the west coast more often from June to August (Sivasubramaniam 1969). Generally, S. orientalis appears in the commercial catches most frequently off the south coast, to a lesser extent off the west and northwest coasts, and least frequently off the southwest and northeast coasts.

\section{Sarda sarda}

The seasonal occurrence of $S$. sarda in various localities is summarized in Tables 8 and 9.

\subsection{Determinants of distribution changes}

Along the California coast there appears to be a relationship between the latitudinal distribution of $S$. chiliensis and sea temperature (Radovich 1963). An upsurge in the average daily $S$. chiliensis catch of partyboat anglers took place with the onset of a warmwater period off California in 1957. Radovich suggested that $S$. chiliensis moved northward into California waters during warm years. He also noted that during warm years, bonitos spawned successfully in California waters, thus further increasing the local population.

From all indications it appears that all the species of Sarda are closely associated with the coast, where the ocean environment may be subject to rapid changes. Demir (1963) stated, however, that $S$. sarda cannot tolerate sudden changes in environment, but they can adapt to gradual changes in temperature ranging from $12^{\circ}$ to

\footnotetext{
${ }^{3}$ Mejia, J., M. Samamé, and A. de Vildoso. 1971. Revisión de la pesqueria del bonito en quas Peruanas. Fourth Session of FAO Panel of Experts for the Facilitation of Tuna Research, La Jolla, Calif., 8-13 November 1971. (Mimeogr.)
} 
Table 8.-Fishing seasons for Sarda sarda.

\begin{tabular}{|c|c|c|c|}
\hline Area & Fishing season & $\begin{array}{l}\text { Peak months } \\
\text { of fishing }\end{array}$ & Source \\
\hline Black Sea & May-October & - & Demir (1963) \\
\hline $\begin{array}{l}\text { Bosporus, Sea of Marmara, } \\
\text { Dardanelles }\end{array}$ & Throughout the year & $\begin{array}{l}\text { April-May, } \\
\text { September-December }\end{array}$ & Demir (1963) \\
\hline Aegean Sea (around Greece) & Throughout the year & - & Serbétis (1955) \\
\hline Eastern Mediterranean (off Spain) & May-June & - & Gruvel (1931) \\
\hline Mediterranean (off Tunisia) & Throughout the year & May-July & Postel (1955b) \\
\hline Eastern tropical Atlantic & October-May & - & Postel (1955b) \\
\hline Eastern Atlantic (off Morocco) & Throughout the year & - & Furnestin et al. (1958) \\
\hline Eastern Atlantic (Bay of Biscay) & Mid-April to mid-May & - & de la Tourrasse (1957) \\
\hline Western Atlantic (Gulf of Maine) & June-October & - & Bigelow and Schroeder (1953) \\
\hline
\end{tabular}

Table 9.-Fishing seasons in the Spanish fishery for Sarda sarda. (From Rodríguez-Roda 1966, table 2.)

\begin{tabular}{lll}
\hline \multicolumn{1}{c}{ Area } & Fishing season & $\begin{array}{c}\text { Peak months of } \\
\text { fishing }\end{array}$ \\
\hline $\begin{array}{l}\text { Bay of Biscay } \\
\text { (along Spanish coast) }\end{array}$ & April-November & July-October \\
$\begin{array}{c}\text { Eastern Atlantic } \\
\text { (off northwest coast } \\
\text { of Spain) }\end{array}$ & April-December & July, August \\
$\begin{array}{c}\text { Eastern Atlantic } \\
\text { (southwest coast of }\end{array}$ & January-December & September, October \\
$\begin{array}{c}\text { Spain) } \\
\text { Western Mediterranean } \\
\text { (southeast coast of }\end{array}$ & January-December & August-October \\
$\begin{array}{c}\text { Spain) } \\
\text { Western Mediterranean } \\
\text { (east coast of Spain) }\end{array}$ & January-December & May, September \\
$\begin{array}{c}\text { Western Mediterranean } \\
\text { (northeast coast of } \\
\text { Spain) }\end{array}$ & January-December & June-November \\
$\begin{array}{c}\text { Western Mediterranean } \\
\text { (Balearic Islands) }\end{array}$ & January-December & May-September \\
$\begin{array}{c}\text { Eastern Atlantic } \\
\text { (Canary Islands) }\end{array}$ & January-December & August, September \\
\hline
\end{tabular}

$27^{\circ} \mathrm{C}$ and salinities between 14 and $39 \%$. Sarda sarda have been taken in the Miramichi estuary, Gulf of St. Lawrence, where the condition must surely be less than oceanic. Sarda orientalis have been found in waters ranging from $13.5^{\circ}$ to $23^{\circ} \mathrm{C}$ (Kishinouye 1923).

\section{BIONOMICS AND LIFE HISTORY}

\subsection{Reproduction}

\subsection{Sexuality}

All four species of Sarda are usually heterosexual, and there are no apparent external anatomical differences between the males and females. In Sarda c. lineolata, however, Magnuson and Prescott (1966) noted a sexual dimorphism in the behavior of this species in captivity. Magnuson and Prescott noted that some $S$. c. lineolata in their observation tank were "wobblers" and that others were "followers." They postulated and subsequently determined that the "wobblers" were females and the "followers" were males. They also determined by their observations that a male bonito was apparently unable to identify the sex of another bonito except by behavioral characteristics. The bonito is normally heterosexual; however, Vildoso (1960) found cases of hermaphroditism in $S . c$. chiliensis in Peruvian waters. It is of interest that Magnuson and Prescott observed that one fish exhibited both a "wobbling" and "following" behavior. They attributed the anomalous behavior of this particular fish to a possible misidentification and did not speculate on the possibility of hermaphroditism or other causes for the aberrant behavior.

As is the case with the other species of bonitos, the sexes cannot be distinguished in $S$. sarda. Apparently, however, some Turkish fishermen can distinguish the sexes by rubbing the skin anterior of the anus with a fingertip. The skin is said to be smooth in the females and rough like emery paper in the males (Demir 1963).

\subsection{Maturity}

\section{Sarda australis}

The literature contains very little information on Sarda australis. Serventy (1941b) reported on three fish caught in January and February 1939 off Wilson's Promontory and Port Albert. The fish weighed between 1.8 and $2.3 \mathrm{~kg}$ ( 4 and $5 \mathrm{lb}$ ); and two, which were females, had "relatively large roes." Whitley (1964) noted that $S$. australis sometimes venture into Victoria in the summer (January to April) and that some of these fish had large roe. He also found that fish ready to spawn were found in February and March off New South Wales.

\section{Sarda chiliensis}

Barrett (1971) determined the gonad index (GI) $(G I=$ $\frac{\omega}{W} \times 10^{2}$, where $w=$ weight of both ovaries in grams and $W=$ body weight in grams) of bonitos and found that female $S$. c. chiliensis off the coast of Chile initially reached sexual maturity at a length of $51 \mathrm{~cm}$. For the bonitos off the coast of Peru, Vildoso (1966) determined that the size at first spawning ranged from 47 to $53 \mathrm{~cm}$. Kuo (1970) stated that in the Northern Hemisphere population of $S$. chiliensis, the females attained sexual maturity at $51 \mathrm{~cm}$ and that the fish was $5 \mathrm{yr}$ old at that length. 


\section{Sarda orientalis}

Although the size of $S$. orientalis at first spawning has not been clearly determined, a $38.6 \mathrm{~cm}$ specimen possessed residual eggs which were presumably remnants from an earlier spawning (Silas 1964). However, Silas indicated that specimens in "ripe running condition or had already spawned, some showing signs of recovery" measured between 480 and $605 \mathrm{~mm}$ from samples collected in 1960 and 1961 at Vizhingam, India. The age of these specimens was not determined. Rao (1964) found four specimens ranging in size from 48 to $55 \mathrm{~cm}$ with running-ripe ovaries in June, August, and September 1959 , also from Vizhingam.

\section{Sarda sarda}

The bonito in the Sea of Marmara and the Bosporus usually attain sexual maturity at the end of the second year, although in some years they may be sexually mature in a year. Two-year-old fish range from 52 to $57 \mathrm{~cm}$ and 1-yr-old fish from 42 to $48 \mathrm{~cm}$.

In the Black Sea, part of the stock of $S$. sarda attains sexual maturity in the second year of life. These 2-yr-old fish are said to vary from 33 to $50 \mathrm{~cm}$. Off the coast of Dakar in the eastern Atlantic, the size at first maturity is $392 \mathrm{~mm}$ for the males and $370 \mathrm{~mm}$ for the females. These fish are less than a year in age.

\subsection{Mating}

As Magnuson and Prescott (1966) pointed out, pelagic schooling fish were assumed to have no discrete courtship behavior and no pairing and were believed to shed eggs and sperm promiscuously while gathered in large active schools. To the contrary, Magnuson and Prescott found that $S$. c. lineolata do exhibit courting and pairing behavior, if only temporarily, and observed pairs of fishes in a sequence of behavior leading to a simultaneous and adjacent release of eggs and milt. The pair of bonitos released the gametes during a circle swimming behavior in which the male swam in tandem with the female in a circular path.

Although some behavioral patterns have been observed only in $S$. c. lineolata, it would not be unreasonable to expect that the other species of Sarda also behave in a similar manner.

\subsection{Fertilization}

External in all four species of Sarda.

$$
3.15 \text { Gonads }
$$

\section{Sarda australis}

No information.
Table 10.-Fecundity of Sarda sarda.

\begin{tabular}{cccl}
\hline Area & $\begin{array}{c}\text { Size of } \\
\text { fish }\end{array}$ & $\begin{array}{c}\text { Fecundity } \\
\text { (No. of eggs) }\end{array}$ & \multicolumn{1}{c}{ Reference } \\
\hline Black Sea & $\begin{array}{c}40-50 \mathrm{~cm} \\
60-70 \mathrm{~cm}\end{array}$ & $\begin{array}{c}700,000-1,000,000 \\
1,500,000-2,000,000\end{array}$ & Zusser (1954) \\
& $70 \mathrm{~cm}$ & $6,000,000$ & \\
Black Sea & - & $450,000-1,000,000$ & Slastenenko (1956) \\
Black Sea & - & $700,000-1,000,000$ & Krotov (1957) \\
Black Sea & $56-65 \mathrm{~cm}$ & $732,160-3,233,580$ & $\begin{array}{c}\text { Mayorova and Tkacheva } \\
\text { (1959) }\end{array}$ \\
Eastern & $(2-3.8 \mathrm{~kg})$ & & Postel (1955a) \\
Atlantic & $60 \mathrm{~cm}$ & 900,000 & \\
\hline
\end{tabular}

\section{Sarda chiliensis}

Vildoso (1963a) estimated the number of ova spawned by a $600 \mathrm{~mm}(3 \mathrm{~kg}$ ) bonito at half a million per spawning season. According to Vildoso, spawning is fractionary. Kuo (1970) estimated that the fecundity of the northern S. chiliensis ranged from 104,900 to 894,200 eggs for fish from 47.6 to $63.7 \mathrm{~cm}$ in fork length. He indicated that the fecundity increased exponentially with size of fish.

\section{Sarda orientalis}

Silas (1964) made fecundity estimates for five mature specimens of $S$. orientalis from the Indian Ocean. He estimated that the females produce 0.08-0.15 million eggs/spawning and 0.24-0.64 million eggs/spawning season. Rao (1964) estimated that the bonito spawns 0.21-0.28 million eggs/spawning and 0.91-1.15 million eggs/spawning season in the Indian Ocean.

\section{Sarda sarda}

Demir (1963) summarized the fecundity determinations for $S$. sarda made by various investigators in the eastern Atlantic (Table 10). The fecundity estimates range from 450,000 to over $3,000,000$ eggs.

\subsection{Spawning}

\section{Sarda australis}

Whitley (1964) indicated the occurrence of fish that were ready to spawn in February.

\section{Sarda chiliensis}

The spawning season for S. c. chiliensis in Chilean waters begins in September, is at a maximum in October and November, and is well over before April (Barrett 1971). The spawning season off the coast of Peru is very similar to that off Chile; peak spawning of bonito extends from October to February (Vildoso 1966). According to both authors, larger, older bonito mature earlier in the spawning season than do the younger fish (Fig. 6).

For the Northern Hemisphere population of $S$. chiliensis, Kuo (1970) investigated several different approaches to determine the spawning season, including 


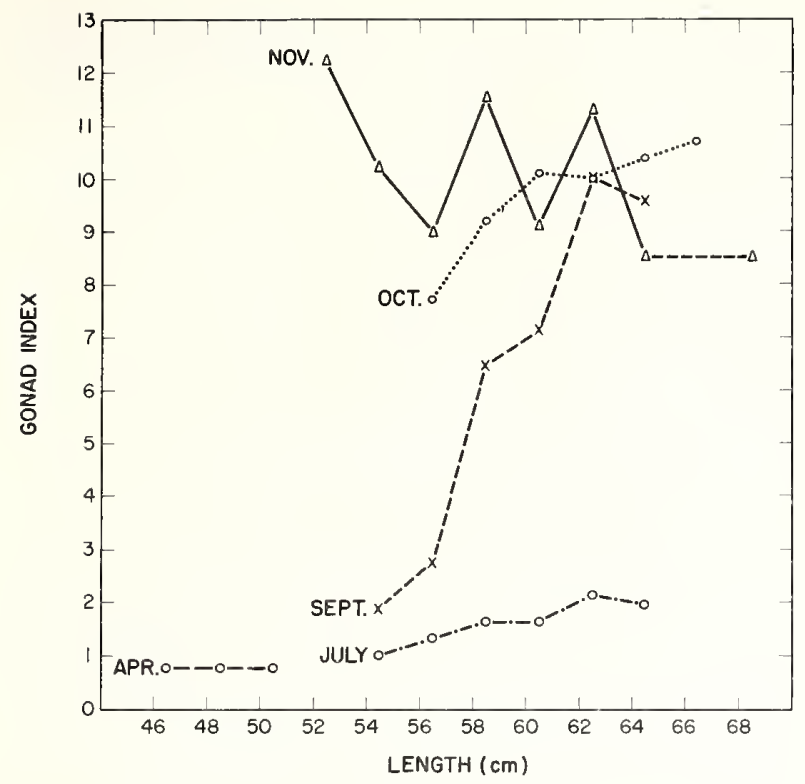

Figure 6.- Mean monthly gonad indices, $G I=\frac{w}{W} \cdot 10^{2}$, by length

class, of female Sarda chiliensis chiliensis sampled from the commercial landings at Iquique, September 1968 to July 1969. (From Barrett 1971, fig. 5.)

the annual cycle in the development of intraovarian oocytes, the annual cycle of frequency distribution of ovum diameters, and the annual change in gonad index. All of the different methods indicated that the spawning season for the Northern Hemisphere S. chiliensis in southern California is from May through July. Kuo speculated that off southern Baja California spawning may start as early as April and may continue into August. He also indicated that the larger fish tend to spawn earlier in the season and longer than the smaller fish. Frey (1971), however, attributed an early spawning season to $S$. c. lineolata between southern California and northern Baja California waters. He stated that the bonitos spawned between January and May in these waters.

The results of an ichthyoplankton survey off Baja California seem to corroborate the conclusions of Kuo (1970). On the basis of the distribution of fertilized eggs, Sokolovskii (1971) showed that $S$. c. lineolata spawned in a relatively large area near the coast (Fig. 3). In early March the most intensive spawning occurred in the southern area and in early April it occurred in the northern area. The depth of the ocean in the spawning area ranged from 40 to $150 \mathrm{~m}$, and practically no bonito eggs were found outside of the $200 \mathrm{~m}$ isobath. Larval bonito were captured at only one station during this survey.

Most of these observations tend to support Klawe (1961b) who, on the basis of the capture of larval and juvenile $S$. chiliensis, had stated that the spawning of this species takes place in the warmer season off California, Baja California, Peru, and northern Chile.

Evidence has also been gathered which suggests that 1and 2-yr-old $S$. c. lineolata spawn in areas influenced by warmwater discharges during spawning periods when the water is cold. Tag returns have shown that small numbers of young fish stay in these areas for as long as 2 yr and provide a small amount of recruitment even in cold years (Collins and MacCall 1977).

\section{Sarda orientalis}

The literature contains very little information on $S$. orientalis spawning in the eastern Pacific and around Hawaii. Klawe (1961b) reported on two larval forms of Sarda from off Baja California that could not be identified to species. The distribution of the northeast population of $S$. chiliensis overlaps or nearly overlaps that of the population of $S$. orientalis at the location of capture of the larvae; therefore, the larvae could be either of the two species.

Nothing is known about the spawning of $S$. orientalis around Hawaii except that a few juveniles have been found in the stomachs of predators (Honolulu Laboratory, Southwest Fisheries Center, unpubl. data), which provides evidence of reproduction.

No formal studies on the spawning of $S$. orientalis in Japanese waters have been made. Kikawa and Staff of the Nankai Regional Fisheries Research Laboratory (1963) presumed that spawning occurs in the coastal waters of the tropical zone in the Indo-Pacific. There apparently is some local unrecorded knowledge of bonito spawning in Japan because Harada et al. (1974) reported that the spawning season is May-June. They caught mature S. orientalis on 15 May and 10 June in traps set near the coast of Oshima Island and used these fish successfully in an artificial fertilization experiment. Mito (1961) gave descriptions of the fertilized eggs of $S$. orientalis found in plankton collections but gave no collection details. Kishinouye (1923) and Yabe et al. (1953) reported on the capture of juvenile bonito in southern Honshu and Kyushu waters.

Off the coast of Vizhingam in the Indian Ocean, S. orientalis spawn from April to September and possibly in other months of the year. Ova diameter frequency distributions indicate the possibility that individual females spawn several batches of ova (Fig. 7) during the spawning season (Silas 1964).

Gorbunova (1963) reported on the larva of $S$. orientalis from the Indian Ocean off the northwest coast of Australia and generalized that spawning is limited to the autumn-winter period. However, this conclusion is based, apparently, on the capture of one larva of $S$. orientalis in December. Gorbunova probably has the seasons confused, for December off the northwest coast of Australia would be closer to summer in the Southern Hemisphere.

\section{Sarda sarda}

Demir (1963) stated that $S$. sarda spawning begins in mid-May, reaches a peak in June, and lasts at least to the end of July. He assumed that the spawning season is the same in the Black, Marmara, and Aegean Seas.

Indications are that the spawning season in the Medi- 


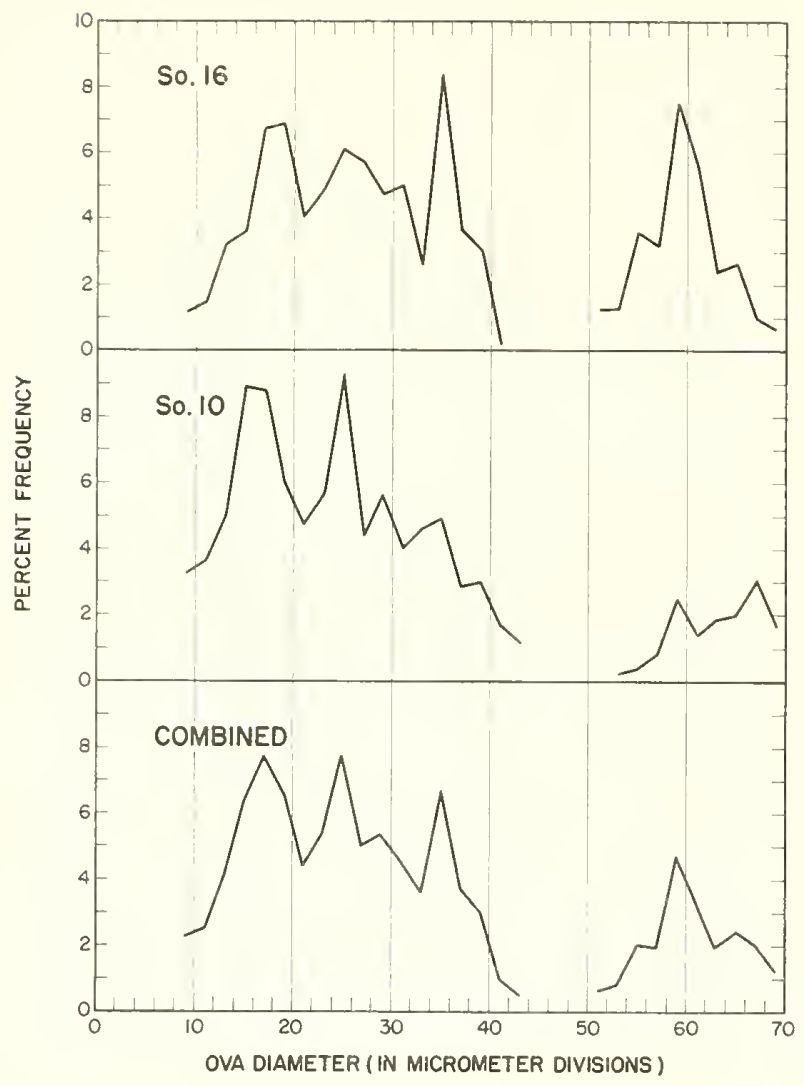

Figure 7.-Ova diameter-frequency polygons of ripe ovaries of the oriental bonito, Sarda orientalis, from the southwest coast of India. The ripe ova were sampled from two of four ripe fish examined from June to September 1959. (From Rao 1964, fig. 3.)

terranean is also from May to July. However, Demir (1963) noted that Dieuzeide et al. (1955) found that the spawning season off the coast of Algeria is from March to May.

Rodríguez-Roda (1966) made observations on the sexual development of S. sarda landed in May, June, and July 1963 and 1964 in the Spanish fishery based at the Mediterranean ports of Barbate and Tarifa. By gross examination of the gonads, he classified the males and females according to six stages of sexual maturity: I, Immature; II, Early maturing; III, Mature; IV, Prespawning; V, Spawning; and, VI, Spent. Data on the monthly percentage distribution of fish in the various stages of sexual maturity were given by Rodríguez-Roda (Table 11). He also computed the GI of the fish for his
Table 12.-Relation between the stage of sexual maturity and the gonadosomatic index $\left(G I=-\frac{w}{W} \cdot 100\right.$, where $w$ is gonad weight and $W$ is fish weight) for Sarda sarda landed at Barbate, Spain in 1964. (From Rodriguez-Roda 1966, table 26.)

\begin{tabular}{ccccccccc}
\hline & \multicolumn{4}{c}{ Males } & & \multicolumn{3}{c}{ Females } \\
\cline { 2 - 3 } $\begin{array}{c}\text { Stage of sexual } \\
\text { maturity }\end{array}$ & Mean & Range & $\begin{array}{c}\text { No. of } \\
\text { fish }\end{array}$ & Mean & Range & $\begin{array}{c}\text { No. of } \\
\text { fish }\end{array}$ \\
\hline I (immature) & - & - & - & 0.56 & $0.42-0.69$ & 2 \\
II (early maturing) & 0.94 & - & 1 & 0.85 & - & 1 \\
III (mature) & 4.15 & $0.96-6.90$ & 30 & 4.44 & $1.77-12.15$ & 23 \\
IV (prespawning) & - & - & - & 5.39 & $3.56-9.40$ & 8 \\
V (spawning) & - & - & - & - & - & - \\
VI (spent) & - & - & - & 2.15 & - & 1 \\
\hline
\end{tabular}

1964 samples using the equation $G I=\frac{w}{W} \cdot 100$, where $w$ is the weight of the gonads and $W$ is the weight of the fish, and determined the relation between the stage of sexual maturity and the GI (Table 12). Rodríguez-Roda noted that the smallest fish with prespawning and spawning gonads were $39.5 \mathrm{~cm}$ for the males and $40.5 \mathrm{~cm}$ for $\mathrm{fe}$ males.

In the eastern Atlantic near the coast of Dakar the spawning season extends from December to June, including peaks in January and April, and June to July in Moroccan waters. Less is known about $S$. sarda spawning in the western Atlantic. Bigelow and Schroeder (1953) stated that the bonito spawns south of the Gulf of Maine in June. However, Sette (1943) reported the collection of bonito eggs near Martha's Vineyard, Mass., in July. Further south off the South Carolina coast Klawe (1961a), based on the capture of a singe $34 \mathrm{~mm}$ bonito, stated that this species spawns in the winter. The capture of a larval bonito (Gorbunova and Salabarrìa 1967) off the coast of Cuba and a juvenile specimen in the central Gulf of Mexico (Klawe and Shimada 1959) indicates some spawning activity in these areas.

\subsection{Spawn}

The fertilized eggs of the bonitos have been described for all the species in the genus except Sarda australis. Except for differences in size, the fertilized eggs at the various developmental stages appear to be quite similar, and it is doubtful if the species could be separated. As examples of differences in size of the fertilized eggs among the species of Sarda, Demir (1963) found that for S. sarda in the Sea of Marmara, the eggs, which were measured after preservation in $4 \%$ Formalin, varied between 1.18 and $1.55 \mathrm{~mm}$ in diameter. The fertilized eggs of $S . c$.

Table 11.-Monthly percentage distribution of Sarda sarda in the various stages of sexual development, Barbate and Tarifa, Spain, in 1963 and 1964. (I, immature; II, early maturing; III, mature; IV, prespawning; V, spawning; VI, spent.) (From Rodríguez-Roda 1966, table 24.)

\begin{tabular}{|c|c|c|c|c|c|c|c|c|c|c|c|c|c|c|}
\hline & \multicolumn{7}{|c|}{ Males } & \multicolumn{7}{|c|}{ Females } \\
\hline & I & II & III & IV & V & $\mathrm{VI}$ & $\begin{array}{c}\text { No. of } \\
\text { fish }\end{array}$ & I & II & III & IV & $\mathrm{V}$ & VI & $\begin{array}{c}\text { No. of } \\
\text { fish }\end{array}$ \\
\hline May & 7.02 & 1.75 & 87.72 & 3.51 & - & 一 & 57 & 30.00 & 15.00 & 55.00 & - & - & - & 20 \\
\hline June & - & - & 73.81 & 23.81 & 2.38 & - & 42 & 2.38 & - & 64.29 & 30.95 & - & 2.38 & 42 \\
\hline July & - & - & 100.00 & - & - & - & 18 & - & - & 54.17 & 41.67 & - & 4.17 & 24 \\
\hline
\end{tabular}


lineolata from off the coast of Baja California measured from 1.4 to $1.8 \mathrm{~mm}$ in diameter (Sokolovskii 1971). However, no mention is made of whether the eggs were measured before or after preservation. Harada et al. (1974) reported that the fertilized eggs of $S$. orientalis were from 1.32 to $1.45 \mathrm{~mm}$ in diameter. Here again it is not clear whether the eggs were measured fresh or after preservation. These fertilized eggs were the result of a successful experiment in artificial fertilization, the first record of success in artificial fertilization for this species.

Because the fertilized eggs of the species of Sarda are similar in appearance, as a typical example Demir's (1963) description of the eggs (Fig. 8) of S. sarda is given below.

The fertilized planktonic eggs of $S$. sarda are spherical, transparent, and, except for the oil globule, colorless. The yolk sac is homogeneous and finely granulated, and varying numbers of oil globules of different sizes are present on its surface.

Although yellow and black pigmentation are present on the developing embryo, only the black pigments (me- lanophores) remain after preservation. The melanophores on the yolk are found on the surface of the sac. On the embryo they initially appear on the dorsal part of the body and later on the head and tail.

\subsection{Preadult phase}

\subsection{Embryonic phase}

See section 3.17.

\subsection{Larvae and adolescent phase}

The size of a newly hatched larva of $S$. chiliensis is given by Barnhart (1927) as $3.75 \mathrm{~mm}$. Newly hatched larvae of $S$. orientalis measured $4.1-4.3 \mathrm{~mm}$ (Harada et al. 1974). As a typical example of the development of the larvae of bonitos, a description of the larval and postlarval development of $S$. sarda is given below. The description is taken from a translation of Padoa (1956).

Embryonic development is rapid and the larva hatches only a day after the closure of the blastopore.
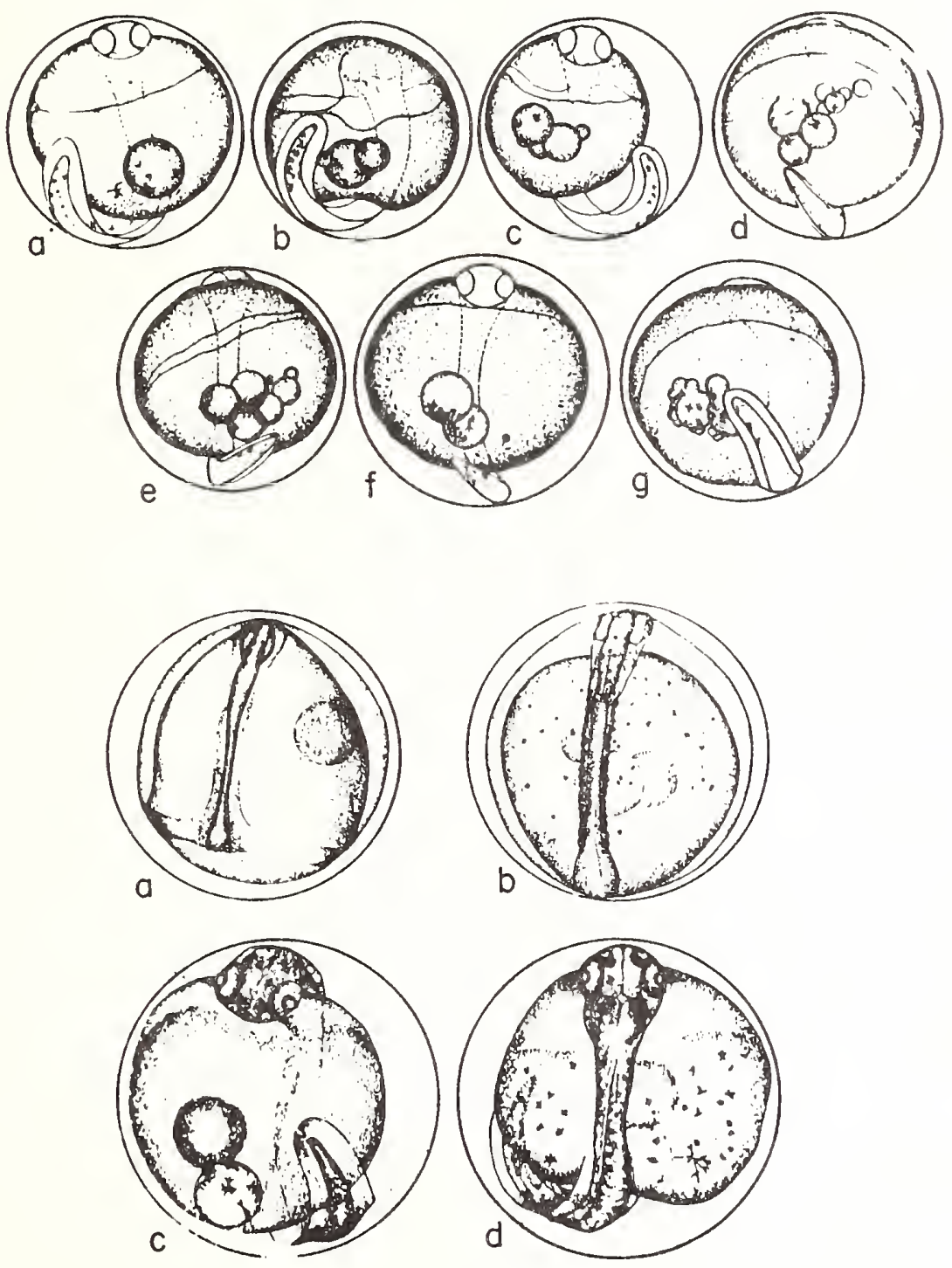

Figure 8.-The fertilized eggs of Sarda sarda at various developmental stages. (Note: The developmental stages were not defined by the authors.) (From Demir and Demir 1961.) 
The mouth of the larva is not yet open, and the eye without pigment at hatching (Fig. 9a). The yolk sac and fin folds are large, and several oil droplets are present in the posterior part of the yolk sac. The anal opening is located a little less than midway between the head and tail. The pectorals are barely outlined. There is a total of about 50 body segments, including 15 preanal and 38 postanal segments.

The yolk is reduced to less than half in a $4.6 \mathrm{~mm}$ specimen 2 days after hatching (Fig. 9b). The mouth is open, the anus has moved forward, and the number of preanal segments is decreased from 15 to 11 and the postanal increased to 39 . The pectorals are well developed and membranous; the hypurals are absent. Melanophores on the trunk are limited to the caudal ventral margin; other melanophores are present in the curve of the peritoneal cavity and a few are found on the profile of the snout.

The yolk is nearly used up in a $4.68 \mathrm{~mm}$ specimen 4 days after hatching (not illustrated). The snout is considerably longer and there are well-defined teeth. There is a posteriorly directed triangular spine at the preopercular margin. The anus is displaced even farther forward to about the 9th segment. The pectorals are unchanged and the hypurals are still absent. The melanophores persist on the caudal ventral margin; the number and size of melanophores are increased on the dorsal peritoneal walls and the head.
The y.olk is exhausted in a $4.20 \mathrm{~mm}$ specimen 6 days after hatching (Fig. 9c). The snout is a little more distinctly pointed and is changing to the subconical form. The preopercular spine is pointed and evident; the preanal distance is about $34 \%$ of the total length. The pectorals are membranous and the rounded margin reaches about the level of the anus; the hypurals are still absent. There are a few irregularly spaced melanophores on the ventral margin of the trunk. The melanophores persist on the peritoneal curve, along the thoracic girdle, and on the upper profile of the head; they are also present at the apex of the snout and in the middle of the mandible.

Melanophores are present on the apex of the snout, on the profile of the head, on the peritoneal curve, and along the thoracic girdle in a $7.2 \mathrm{~mm}$ specimen (Fig. 10c). Black pigments are almost completely lacking on the caudal trunk and limited to a few dispersed elements along the ventral margin. Two series of preopercular spines (an anterior of three and a posterior of six), of which the two central ones are very long, are now developed; two other spines are present on the posterior margin of the otocysts. About 10 pointed teeth are on each side of the maxillary and the mandible. Outlines of about 13 rays, the future second dorsal and anal fins, can be counted. The preanal distance now represents $42 \%$ of the total length and the distance from the snout to the
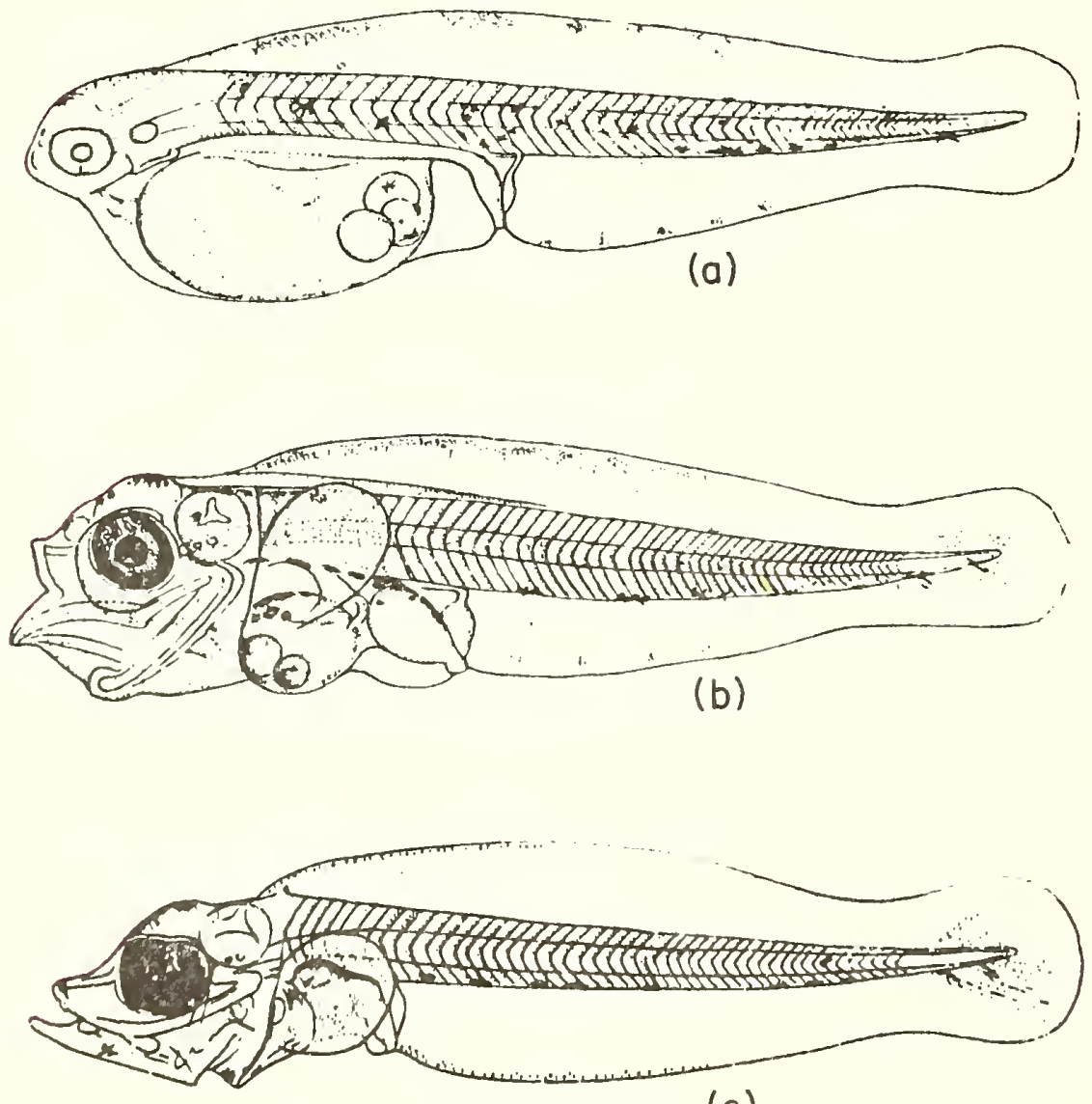

(c)
Figure 9.-Prelarvae of Sarda sarda: (a) $4.32-\mathrm{mm}$ prelarva (from Padoa 1956, fig. 309); (b) $4.6-\mathrm{mm}$ prelarva (from Padoa 1956 , fig. 310 ); (c) 4.20 -mm prelarva (from Padoa 1956, fig. 311). 


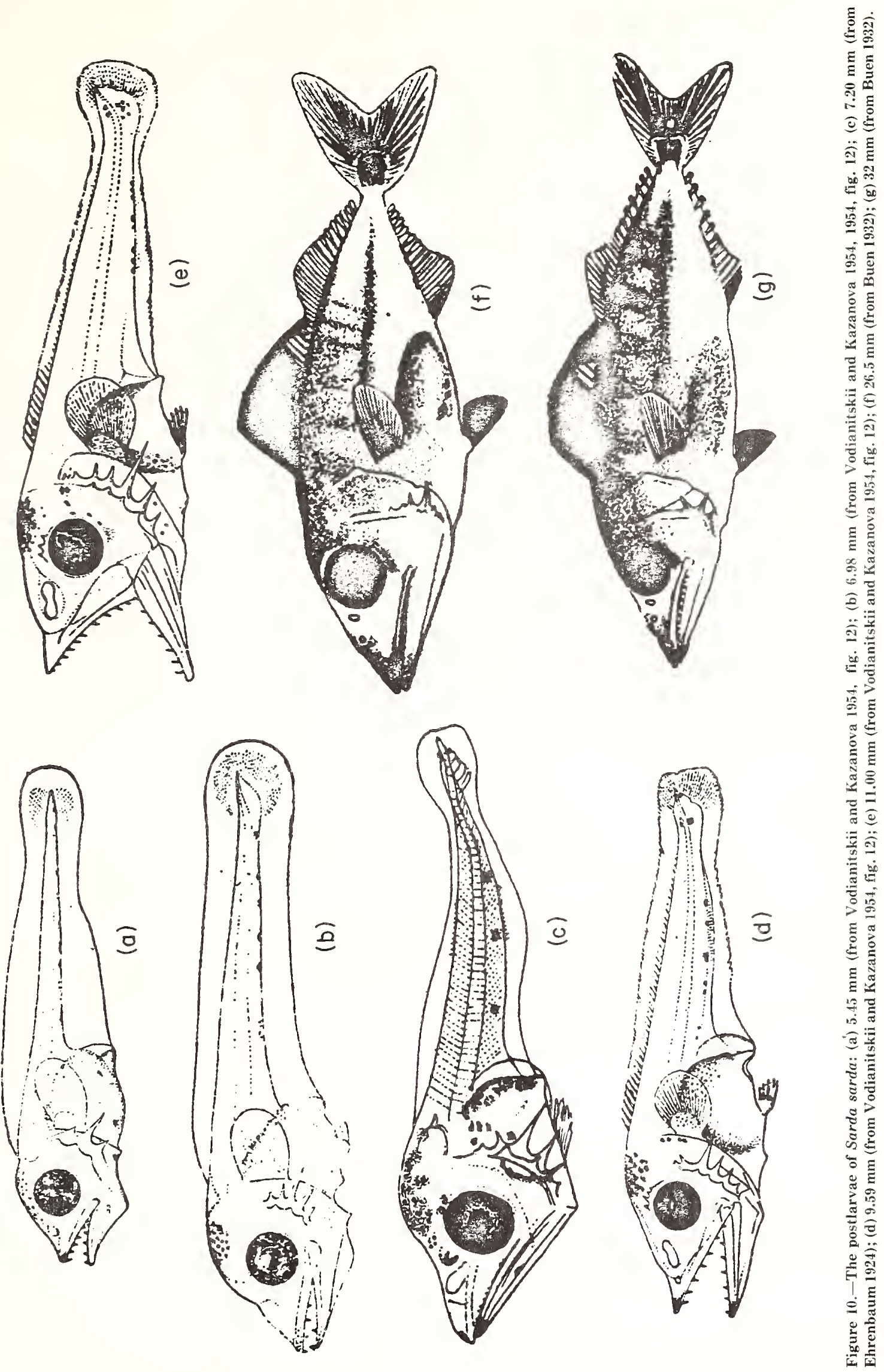


insertion of the anal fin, $65 \%$; there are about 20 segments in the postanal region.

In a $26.5 \mathrm{~mm}$ specimen, the preopercular spines are well-evident but small (Fig. 10f). The caudal fin is now forked; the pectoral and ventral fins are relatively small. The membrane that is continuous with the second dorsal and anal fins still unites the finlets. The first dorsal is covered with black pigments except for a clear space at the base of the 10th to the 13th rays; the other fins are transparent. Fine black pigments are on the snout, the nape, and the dorsal region of the trunk where six vertical bands, which extend from the dorsal edge to about the middle of the flanks, begin to appear. A dark horizontal line separates the pigmented dorsal portion from the ventral, unpigmented portion. In a $32 \mathrm{~mm}$ specimen the preopercular spines are smaller but still evident (Fig. $10 \mathrm{~g})$. The membrane still joins the finlets and the fin coloration is unchanged. The pigmentation on the head is increased and the six vertical bands are quite pronounced.

Illustrations of postlarval $S$. sarda given by Vodianitskii and Kazanova (1954) are also shown in Figure 10.

Pinkas (1961) and Klawe (1961b) gave descriptions of postlarval S. chiliensis, and Jones (1960), Gorbunova (1963), and Harada et al. (1974) described larval and postlarval S. orientalis (Figs. 11, 12).

Except for $S$. chiliensis and $S$. orientalis in the eastern Pacific, where there may be some overlap in the distribution of these two species, the problem of identifying and separating the larval and juvenile species within the genus does not occur because the species are allopatric. As for the larval forms of $S$. chiliensis and $S$. orientalis in the eastern Pacific, Klawe (1961b) stated that it would be impossible to separate the two species without a complete developmental series of both species. Klawe further noted that it should be possible to distinguish juvenile $S$. chiliensis and $S$. orientalis from each other based on gill raker counts even at a relatively small size. Pinkas (1961) pointed out other characters (number of teeth on lower jaw and presence or absence of posterior gill teeth) that could be used to separate $S$. chiliensis $>24 \mathrm{~mm}$ from similar sized $S$. velox ( $=S$. orientalis $)$.

Once the juveniles acquire the full adult complement of certain characters, which seems to be at a relatively small size (Pinkas 1961; Klawe 1961b), the summary of distinguishing characters (Table 1) for the four species of Sarda compiled by Collette and Chao (1975) indicates that the juveniles should be separable without difficulty. Sarda australis, S. chiliensis, and $S$. orientalis can be separated from each other on the basis of gill raker counts while $S$. sarda can be distinguished from all the others by the number of vertebrae.

\subsection{Adult phase}

\subsection{Longevity}

See section 4.13 .
3.32 Hardiness

See section 3.52.

3.33 Competitors

\section{Sarda chiliensis}

The relationships of $S . c$. lineolata with the other species occupying the same areas off southern California are not clear. However, recent changes in the species composition of pelagic fish stocks off California shores may involve the bonito as well as Pacific sardine, Sardinops sagax, and northern anchovies, Engraulis mordax (Frey 1971). Presumably these changes would involve the ability of the various species to compete with one another for food and space. Behavior studies on S. c. lineolata indicate that they can compete very well with other species in obtaining food. In a fish tank containing $\mathrm{Pa}$ cific barracuda, Sphyraena argentea; yellowtail, Seriola dorsalis; and tarpon, Megalops atlantica, S. c. lineolata was the first species to reach and ingest food tossed onto the surface (Magnuson and Prescott 1966). Magnuson and Prescott noted that the high speed of $S$. c. lineolata gives it an advantage over the other species in a "scramble" type of competition.

\section{Sarda orientalis}

In the Indian Ocean adult $S$. orientalis are often caught together with Euthynnus affinis, Auxis spp., Thunnus tonggol, and Scomberomorus spp. and presumably compete with these species for food (Silas 1963). Demir (1963) stated that all predatory fishes and dolphins are potential competitors of $S$. sarda, including Delphinus delphis ponticus, Tursiops truncatus, Scomber scombrus, Trachurus mediterraneus, Pomatomus saltatrix in the Black Sea, and additionally, Scomber japonicus, Auxis rochei, and Euthynnus alletteratus in the Sea of Marmara.

\subsection{Parasites, diseases, injuries, and ab- normalities}

Records of parasitism on bonitos include a trematode, Didymozoon pelamyzis, from the gill lamella of S. sarda from the Black Sea, Sea of Marmara, and the Mediterranean (Dawes 1946; Demir 1963). Larvae of the cestode Callitetrarhynchus gracilis have been found in the body cavity and the isopod Livoneca sp. from the gill lamellae of S. sarda (Postel 1954). Parasitic copepods Caligus sarda (Pearse 1952) and Ceratocolax euthynni (Vervoort 1971) have been found on S. sarda. Silas (1967) and Silas and Ummerkutty (1967) produced a detailed listing of the parasites of scombroid fishes, including Sarda (Table 13).

Two stripeless S. c. lineolata have been recorded from waters off La Jolla, Calif. (Matsumoto et al. 1969). These specimens possessed all the meristic characters typical of $S$. c. lineolata except that they lacked stripes. 

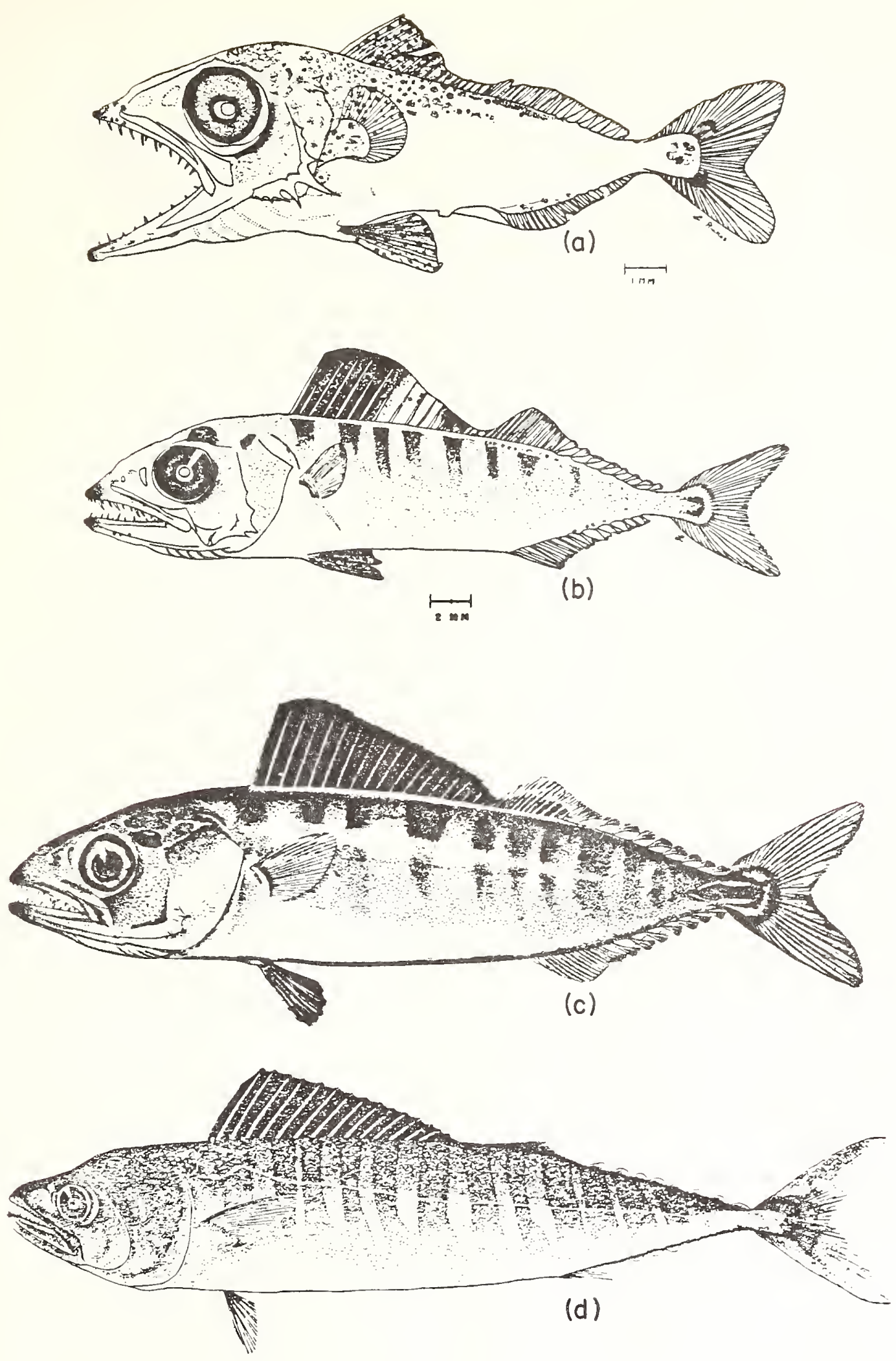

Figure 11.-Postlarval Sarda chiliensis: (a) $16.7 \mathrm{~mm}$ fork length (from Pinkas 1961, fig. 4); (b) $33.0 \mathrm{~mm}$ fork length (from Pinkas 1961, fig. 5); (c) $42 \mathrm{~mm}$ (from Klawe 1961b, fig. 3); (d) $160 \mathrm{~mm}$ (from Klawe 1961b, fig. 4). 


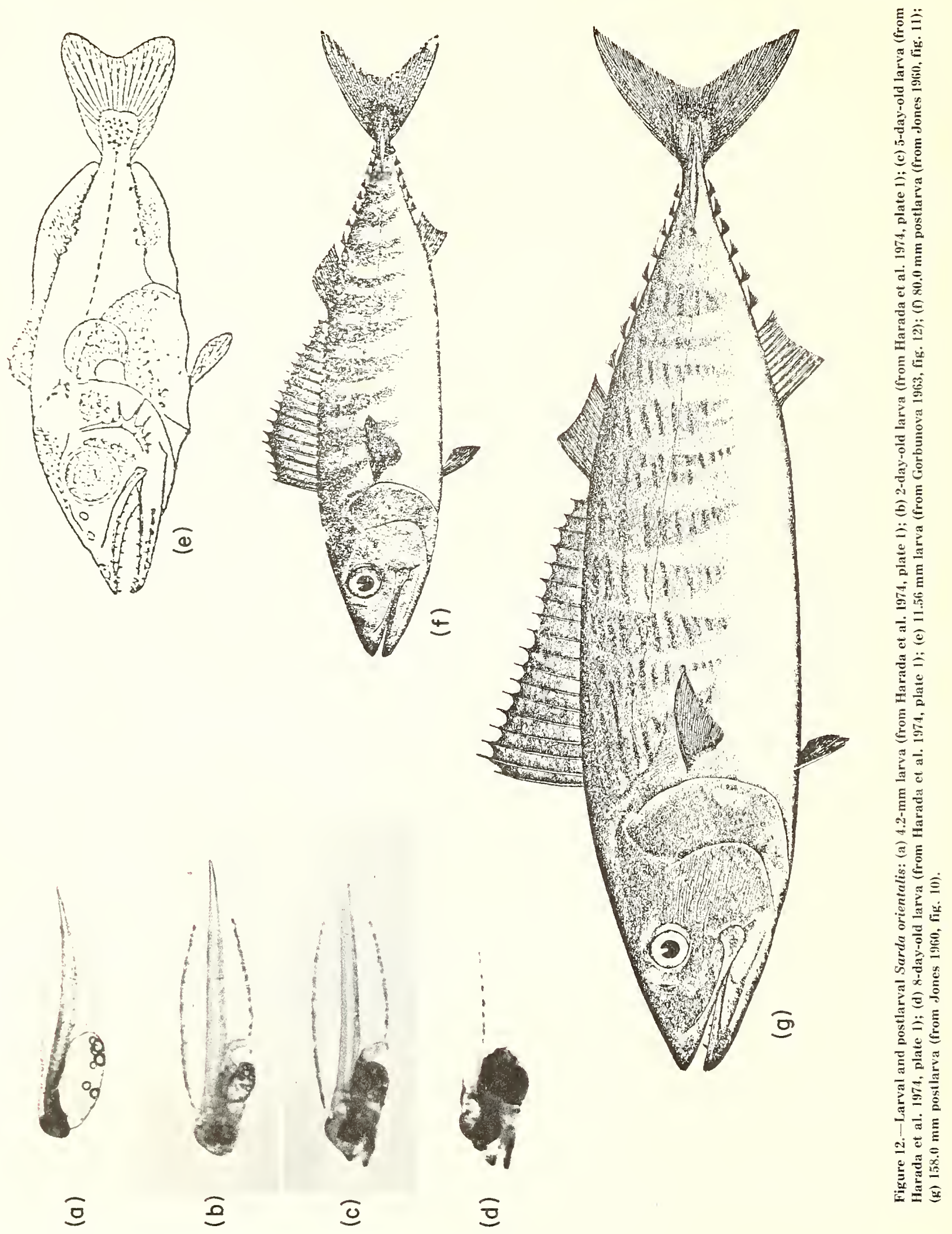


Table 13.-Parasites of Sarda. (Modified from Silas 1967; Silas and Ummerkutty 1967.)

\begin{tabular}{|c|c|c|c|}
\hline Copepods & $\begin{array}{c}\text { Monogenetic } \\
\text { trematodes }\end{array}$ & $\begin{array}{c}\text { Digenetic } \\
\text { trematodes }\end{array}$ & Cestodes \\
\hline & & hiliensis & \\
\hline $\begin{array}{l}\text { Caligus bonito } \\
\text { Caligus mutabilis } \\
\text { Pseudocycnus } \\
\text { appendiculatus }\end{array}$ & & & \\
\hline
\end{tabular}

Sarda orientalis

Caligus bonito Capsala caballerio Bucephalopsis cybii

Caligus productus

Sarda sarda

Caligus bonito

Caligus mutabilis

Caligus pelamydis

Caligus productus

\begin{abstract}
Capsala pelamydis Hexostoma pricei

Hexostoma thynni
\end{abstract}

\author{
Aponurus tschugunowi \\ Atalostrophion sardae \\ Bucephalopsis arcuata \\ Dinurus barbatus \\ Hirudinella clavata \\ Lecithochirum \\ caudiporum \\ Lecithochirum texanum \\ Nematobothrium \\ pelamydis \\ Opecoelides vitellosus \\ Rhipidocotyle \\ angusticollis \\ Tormopsolus orientalis? \\ Unitubulotestes sardae
}

\author{
Grillotia erinaceus \\ Lacistorhynchus \\ tenus \\ Scolex pleuronectis \\ Tentacularia bicolor \\ Tentacularia coryphaena \\ Tetrarhynchus \\ megabothrium ${ }^{1}$ \\ Tetrarhynchus \\ scomber-pelamys ${ }^{1-2}$ \\ Tetrarhynchus sp.
}

'Species incertae sedis.

${ }^{2}$ Indicates doubtful record.

${ }^{3}$ Forms unidentifiable.

\subsection{Nutrition and growth}

\subsection{Feeding}

Magnuson and Heitz (1971) examined the relation between the gill raker morphology and the food habits of scombrid fishes, including S. c. lineolata. In the past, the high diversity of food organisms in the stomachs of scombrids gave rise to the opinion that scombrids are nonselective feeders. However, Magnuson and Heitz pointed out that selectivity does exist in terms of food size in scombrid food habits in that the stomach contents of small and large fish of the same species were dissimilar. They suggest that larger predators have a reduced ability to catch small prey (crustaceans) because of a relatively large gap between the gill rakers. Among scombrids of the same size $S$. c. lineolata and $S$. orientalis had the largest gill gaps $(1.8-3.3 \mathrm{~mm})$. The relative unimportance of crustaceans in the food habits of $S$. c. lineolata noted by Pinkas et al. (1971) could be related in part to the large gill gaps in this species. The data presented by Magnuson and Heitz (1971) also indicate a relationship between the number of gill rakers and the gill raker gap, i.e., the greater the number of gill rakers, the smaller the gill raker gap. Sarda orientalis have fewer gill rakers than S. chiliensis (Collette and Chao 1975), and as Magnuson and Heitz's data show, the gill raker gap is greater in $S$. orientalis. Therefore, it would be expected that the diet of S. c. lineolata would contain a larger proportion of smaller organisms than that of S. orientalis.

$$
3.42 \text { Food }
$$

\section{Sarda australis}

Only a few miscellaneous observations are available on the feeding habits of the Australian bonito. Particularly during the winter months, S. australis occurs commonly in schools in the inshore coastal waters of Queensland and feeds on hardyheads, Pranesus ogilbyi; pilchards, Sardinops neopilchardus; and anchovies, Engraulis australis (Grant 1972). Munro (1958) indicated that they also feed on mackerel scad, Trachurus mccullochi.

\section{Sarda chiliensis}

A detailed study of the food habits of S. c. lineolata was conducted by Pinkas et al. (1971) based on a total of 1,498 stomachs collected in 1968 and 1969 from fish captured in nearshore waters of southern California and Baja California. Their study clearly showed that the northern anchovy, Engraulis mordax, was the major food item in the diet of $S$. c. lineolata. The common squid, Loligo opalescens, ranked next in importance, and miscellaneous fishes and a few crustaceans made up the small remainder of the diet of $S$. c. lineolata (Table 14). 
Table 14.-Food of Sarda chiliensis lineolata, 1968 and 1969. (From Pinkas et al. 1971.)

\begin{tabular}{|c|c|c|c|c|c|c|}
\hline Food items & Number & $\begin{array}{l}\text { Percent } \\
\text { number }\end{array}$ & $\begin{array}{c}\text { Volume } \\
(\mathrm{ml})\end{array}$ & $\begin{array}{l}\text { Percent } \\
\text { volume }\end{array}$ & $\begin{array}{c}\text { Frequency } \\
\text { of } \\
\text { occurrence }\end{array}$ & $\begin{array}{c}\text { Percent } \\
\text { frequency of } \\
\text { occurrence }\end{array}$ \\
\hline \multicolumn{7}{|l|}{ Fishes } \\
\hline \multicolumn{7}{|l|}{ Engraulidae } \\
\hline Engraulis mordax & 4,159 & 75.5 & $11,356.4$ & 75.9 & 462 & 56.3 \\
\hline \multicolumn{7}{|l|}{ Scomberesocidae } \\
\hline Cololabis saira & 27 & 0.5 & 190.8 & 1.3 & 16 & 1.9 \\
\hline \multicolumn{7}{|l|}{ Gadidae } \\
\hline Merluccius productus & 24 & 0.4 & 6.8 & $<0.1$ & 15 & 1.8 \\
\hline \multicolumn{7}{|l|}{ Carangidae } \\
\hline Trachurus symmetricus & 16 & 0.3 & 185.6 & 1.2 & 13 & 1.6 \\
\hline \multicolumn{7}{|l|}{ Sciaenidae } \\
\hline Genyonemus lineatus & 1 & $<0.1$ & 38.0 & 0.3 & 1 & $0.1+$ \\
\hline Seriphus politus & 3 & +0.1 & 1.3 & $<0.1$ & 2 & $0.2+$ \\
\hline \multicolumn{7}{|l|}{ Embiotocidae } \\
\hline Brachyistius frenatus & 1 & $<0.1$ & 10.0 & $<0.1$ & 1 & $0.1+$ \\
\hline Cymatogaster aggregata & 1 & $<0.1$ & 14.0 & 0.1 & 1 & $0.1+$ \\
\hline Zalembius rosaceus & 1 & $<0.1$ & 9.0 & $<0.1$ & 1 & $0.1+$ \\
\hline \multicolumn{7}{|l|}{ Scorpaenidae } \\
\hline Sebastodes spp. & 12 & 0.2 & 5.8 & $<0.1$ & 5 & 0.6 \\
\hline \multicolumn{7}{|l|}{ Stromateidae } \\
\hline Peprilus simillimus & 7 & $0.1+$ & 195.0 & 1.3 & 6 & 0.7 \\
\hline \multicolumn{7}{|l|}{ Bothidae } \\
\hline Citharichthys sordidus & 1 & $<0.1$ & 0.6 & $<0.1$ & 1 & $0.1+$ \\
\hline Unidentified fishes & 765 & 13.9 & 223.8 & 1.5 & 185 & 22.5 \\
\hline \multicolumn{7}{|l|}{ Subtotal, fishes other than } \\
\hline Engraulidae & 859 & 15.6 & 880.7 & 5.9 & 247 & 30.1 \\
\hline Subtotal, all fishes & 5,018 & 91.1 & $12,237.1$ & 81.8 & 709 & 86.4 \\
\hline \multicolumn{7}{|l|}{ Cephalopods } \\
\hline Loligo opalescens & 448 & 8.1 & $2,690.7$ & 18.0 & 207 & 25.1 \\
\hline Onychoteuthis boreali-japonicus & 1 & $<0.1$ & 3.7 ) & & 1 & $0.1+$ \\
\hline Unidentified cephalopods & 17 & $0.3+$ & 9.9 & & 16 & 2.0 \\
\hline Crustaceans & & & & 0.2 & & \\
\hline Pleuroncodes planipes & 4 & $<0.1$ & 5.6 & & 4 & 0.5 \\
\hline Crab megalops larvae & 3 & $<0.1$ & 0.1 & & 1 & $0.1+$ \\
\hline Unidentified animals & 19 & $0.3+$ & $4.7 /$ & & 17 & 2.0 \\
\hline $\begin{array}{l}\text { Subtotal, all invertebrates } \\
\text { (except Loligo opalescens) }\end{array}$ & & & & & & \\
\hline and unidentified animals & 44 & 0.8 & 24.0 & 0.2 & 39 & 4.8 \\
\hline Totals & 5,510 & 100.0 & $14,951.8$ & 100.0 & - & 一 \\
\hline
\end{tabular}

There was a seasonal variation in the importance of the common squid in the diet of $S$. c. lineolata. Squid was most important in the first and second quarters of the year but was less important in the third quarter of the year. This seasonal pattern of the importance of squid in the bonito's diet was related to the seasonal concentrating behavior of squid during its reproductive cycle.

\section{Sarda orientalis}

Information on the food and feeding habits of $S$. orientalis in Japanese waters is fragmentary. Yabe et al. (1953) examined 18 stomachs from juvenile $S$. orientalis in southern Kyushu waters. Fifteen of the 18 stomachs were empty, 2 of the stomachs contained Engraulis japonicus remains, and 1 stomach contained unidentifiable fish remains. Yokota et al. (1961) examined stomachs of $24 \mathrm{~S}$. orientalis caught in about the same area and found a total of five saury, one Sphyraena sp., one squid, and one carangid in the stomachs.
Kumaran (1964) investigated the food habits of S. orientalis in the Indian Ocean based on 43 specimens ranging in length from 85 to $305 \mathrm{~mm}$. The most important single food item was Anchoviella commersonii. Fishes of lesser importance in the diet were Leiognathus insidiator, Decapterus russelli, and Sardinella sp. Kumaran noted that the variety of food organisms was smaller in the stomachs of $S$. orientalis as compared with Euthynnus affinis and Auxis. He gave as the reason for this the fact that all the $S$. orientalis specimens were collected from a single locality. Sivasubramaniam (1969) looked at the food-bearing stomachs of $11 \mathrm{~S}$. orientalis caught in the waters around Sri Lanka. Nearly $60 \%$ by volume of the food consisted of a clupeoid fish, $18 \%$ cephalopod mollusk (squid and octopus), 15\% decapod crustacea, and $7 \%$ miscellaneous items including unidentified fishes.

\section{Sarda sarda}

More information is available on the food and feeding habits of $S$. sarda, including information on larval and 
juvenile stages. Larval $S$. sarda about $5 \mathrm{~mm}$ long start active feeding even before the yolk sac is completely absorbed. Larvae >6-7 mm feed on relatively large organisms, including fish larvae, but prefer copepods. Juveniles $>18-20 \mathrm{~mm}$ feed on the larvae of anchovy, horse mackerel, and S. sarda (Mayorova and Tkacheva 1959). Zusser (1954) reporteci a Pseudocalanus in the stomach of a $7.2 \mathrm{~cm}$ juvenile and a $4.5 \mathrm{~cm}$ long anchovy in a $8.7 \mathrm{~cm}$ juvenile. Demir (1963) found a single $3.5 \mathrm{~cm}$ horse mackerel from the stomachs of 44 juvenile $S$. sarda ranging in length from 6.5 to $16 \mathrm{~cm}$ taken in the Black Sea, the Sea of Marmara, and the Bosporus from 1957 to 1959. Because of the preponderance of empty stomachs, Demir believes that the juveniles, like the adults, regurgitate their food at the moment of capture.

Demir (1963) stated that adult S. sarda is an insatiable predator that feeds diurnally. Feeding in Turkish waters is much more vigorous in the early morning and towards evening. Demir noted that the feeding season is usually from the second half of April to the end of October in Turkish waters. Sarda sarda adults primarily feed on smaller schooling fishes, the species depending on the locality (Table 15).

In the western Atlantic in the Gulf of Maine, S. sarda prey on mackerel, alewives, menhaden, other small fishes such as launce and silverside, and squid (Bigelow and Schroeder 1953). Boschung (1966) examined the stomachs of $52 \mathrm{~S}$. sarda taken during a fishing tournament in the Gulf of Mexico and noted that the fish had fed on a variety of fishes and invertebrates. They in-

Table 15.-Food of Sarda sarda in the Black Sea, Sea of Marmara, and the eastern Atlantic. (From Berg et al. 1949; Postel 1954; Zusser 1954; Slastenenko 1956; Ionescu et al. 1958; Demir 1963.).

Black Sea
Engraulis encrasicholus Spratella sprattus phalerica Scomber scombrus Mullus barbatus Ammodytes cicerellus

Trachurus mediterraneus
Pomatomus saltatrix (young) Sarda sarda (young) Mugil spp. Atherina spp. Gobiidae

\begin{tabular}{ll}
\multicolumn{2}{c}{ Sea of Marmara } \\
Important food items & \\
Engraulis encrasicholus & Clupea pilchardus \\
Spratella sprattus phalerica & Ammodytes cicerellus \\
Scomber scombrus & Trachurus mediterraneus \\
Scomber colias & \\
Less important food items & \\
Smaris alceda & Mullus barbatus \\
Trachurus trachurus & Atherina spp. \\
Boops boops &
\end{tabular}

Atlantic Ocean near Dakar, Senegal

Sardinella sp.

Engraulis sp.

Scomber.colias

Ammodytes sp.

Planktonic crustaceans

Caprella

Euphausiid spp. cluded: a clupeid (probably Harengula pensacolae); harvestfish, Peprilus paru; spot, Leiostomus xanthurus; anchovies, Anchoa sp.; mackerel, Scomberomorus sp.; sea robin, Prionotus sp.; squid, Loligo sp.; shrimp, Penaeus sp.; and unidentified fishes.

Sarda sarda can swallow relatively large prey and the adults and juveniles are both cannibalistic. There is a record of a $38 \mathrm{~cm} S$. sarda from the stomach of a $63 \mathrm{~cm}$ fish (Zusser 1954).

\subsection{Growth rate}

\section{Sarda australis}

There is almost nothing in the literature on the age and growth of $S$. australis except that they grow to $91.4 \mathrm{~cm}$ (36 in) (Ogilby 1954).

\section{Sarda chiliensis}

In the waters between southern California and northern Baja California $S$. c. lineolata spawns between January and May and the pelagic fertilized eggs take about 3 days to hatch. Young S. c. lineolata are first observed in the early summer when they are $15.7-25.4 \mathrm{~cm}(6-10 \mathrm{in})$ and by the following spring they are about $38.1 \mathrm{~cm}$ (15 in) long and weigh from 0.7 to $0.9 \mathrm{~kg}$ ( 1.5 to $2 \mathrm{lb}$ ). In the fall these fish may weigh $1.4 \mathrm{~kg}(3 \mathrm{lb})$ or more and by the following year in May, they may weigh $2.7-3.2 \mathrm{~kg}$ (6-7 lb). When they are $4 \mathrm{yr}$ old, they are $71.1 \mathrm{~cm}$ (28 in) and weigh about $5.4 \mathrm{~kg}$ (12 lb) (Frey 1971). These data are probably the result of random observations and not a systematic study.

Kuo (1970) made a detailed study of the growth of $S$. chiliensis from southern California waters and from Peru based on otoliths (Fig. 13). Kuo fitted the von Bertalanffy growth function to his data and found that the lengthat-age of bonito from the two areas did not differ for age 1,2 , and 6 fish but that there was a significant difference in size of fish 3-5 yr old (Table 16). The growth equations obtained for the northern and southern populations, respectively, were:

$$
L_{\mathrm{t}}=2,661\left[1-e^{-0.038(t \div 0.60)}\right]
$$

and

$$
L_{\mathrm{t}}=1,014\left[1-e^{-0.154(\mathrm{t} \div 0.015)}\right] \text {, }
$$

where $L_{\mathrm{t}}$ is fork length in millimeters and $t$ is actual age in years.

Campbell and Collins (1975) also determined the age and growth of the northern population of $S$. chiliensis based on a sample of 3,139 fish ranging in length from 23 to $79 \mathrm{~cm}$ landed at the canneries in San Pedro, Calif. These fish were caught in an area between central Baja California and Point Conception, Calif., from 1968 to 1974. Like Kuo (1970), Campbell and Collins used otoliths to age the fish and used the von Bertalanffy growth function to describe the growth as shown below: 


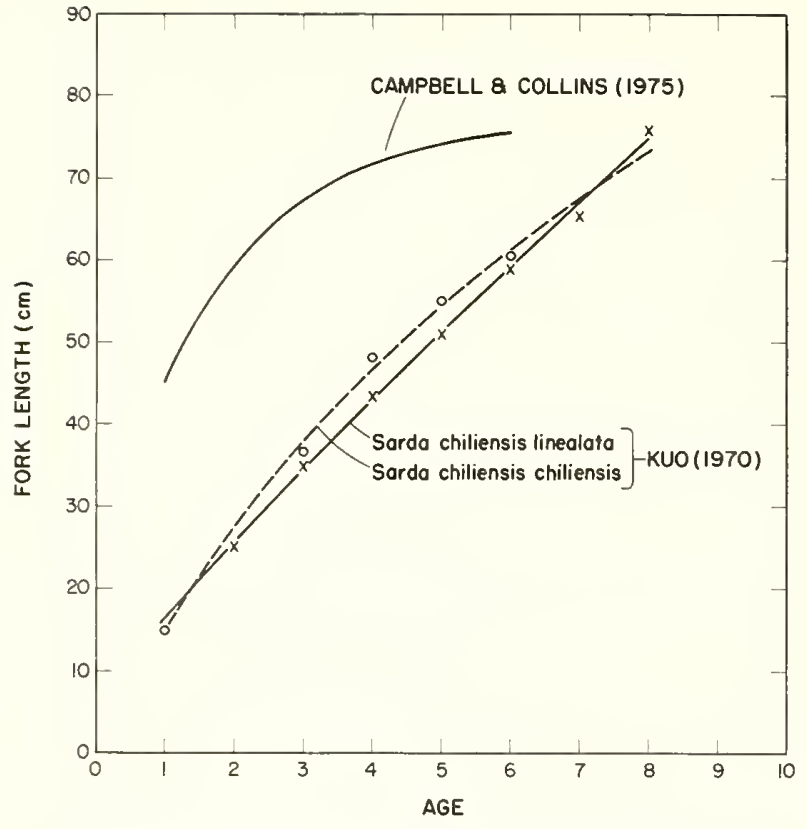

Figure 13.-Growth of Sarda chiliensis from southern California and Peru. (Note: The abscissa of the Campbell and Collins curve is age class.) (From Kuo 1970; Campbell and Collins 1975, fig. 4.)

Table 16.-Age-length data for the subspecies of Sarda chiliensis. (From Kuo 1970, table 14.)

\begin{tabular}{|c|c|c|c|c|c|}
\hline Age & Species $^{1}$ & $\begin{array}{c}\text { Mean } \\
\text { length } \\
(\mathrm{mm})\end{array}$ & $\begin{array}{c}\text { Standard } \\
\text { errar }\end{array}$ & $\begin{array}{c}\text { Canfidence } \\
\text { interval } \\
(\mathrm{mm})\end{array}$ & $N$ \\
\hline \multirow[t]{2}{*}{1} & linealata & 152 & 0.95 & $150-154$ & 222 \\
\hline & chiliensis & 151 & 1.99 & $147-155$ & 141 \\
\hline \multirow[t]{2}{*}{2} & linealata & 252 & 1.28 & $249-254$ & 219 \\
\hline & chiliensis & 256 & 2.76 & $250-261$ & 137 \\
\hline \multirow[t]{2}{*}{3} & lineolata & 347 & 1.70 & $344-351$ & 212 \\
\hline & chiliensis & 364 & 6.02 & $352-376$ & 43 \\
\hline \multirow[t]{2}{*}{4} & lineolata & 433 & 2.26 & $429-438$ & 182 \\
\hline & chiliensis & 480 & 7.01 & $466-494$ & 26 \\
\hline \multirow[t]{2}{*}{5} & lineolata & 509 & 3.19 & $503-515$ & 133 \\
\hline & chiliensis & 550 & 7.27 & $535-565$ & 25 \\
\hline \multirow[t]{2}{*}{6} & lineolata & 585 & 4.79 & $576-595$ & 74 \\
\hline & chiliensis & 604 & 9.18 & $585-623$ & 24 \\
\hline \multirow[t]{2}{*}{7} & linealata & 652 & 13.00 & $625-678$ & 35 \\
\hline & chiliensis & - & - & - & 0 \\
\hline \multirow[t]{2}{*}{8} & linealata & 756 & 12.10 & $728-783$ & 9 \\
\hline & chiliensis & - & - & - & 0 \\
\hline
\end{tabular}

lineolata = Sarda chiliensis linealata. [Narthern Hemisphere]

chiliensis = Sardachiliensis chiliensis. [Sauthern Hemisphere]

$$
L_{\mathrm{t}}=76.87\left[1-e^{-0.6215(\mathrm{t} \div 0.410)}\right] \text {, }
$$

where $L_{\mathrm{t}}$ is fork length in centimeters and $t$ is age at capture, which is about $0.375 \mathrm{yr}$ (September) older than the given age.

The length-age relationship predicted by the curve for fish taken in the fishery is shown below:

$\begin{array}{cc}\text { Age } & \text { Fork length }(\mathrm{cm}) \\ 1 & 44.9 \\ 2 & 59.7\end{array}$

$\begin{array}{ll}3 & 67.6 \\ 4 & 71.9 \\ 5 & 74.2 \\ 6 & 75.4\end{array}$

The growth curve is also shown in Figure 13.

The maximum size of $S$. chiliensis in the Northern Hemisphere is about $101.6 \mathrm{~cm}$ (40 in) and about $11.3 \mathrm{~kg}$ $(25 \mathrm{lb})$. There is an unverified record of a $16.8 \mathrm{~kg}(37 \mathrm{lb})$ specimen, but bonito over $11.3 \mathrm{~kg}$ are rare (Frey 1971). In light of these observations, the $L_{\infty}$ of $2,661 \mathrm{~mm}$ obtained by Kuo (1970) for the Northern Hemisphere bonito seems unreasonably large. On the other hand, as noted by Campbell and Collins (1975), the $L_{\infty}$ predicted by the von Bertalanffy growth function as fitted to their data was less than what they had observed in the California fishery and much less than the maximum length of $S$. chiliensis $(101.6 \mathrm{~cm})$ in the literature. They noted that the discrepancy could have been caused by the lack of fish larger than $79 \mathrm{~cm}$ in their sample.

It is of interest also that the growth curves obtained by Kuo (1970) and Campbell and Collins (1975) for the northern population of $S$. chiliensis are quite different. The results obtained by Campbell and Collins indicate a rapid growth rate during the first $3 \mathrm{yr}$ and a tapering off to a relatively low rate thereafter. Kuo's growth curve on the other hand shows only a slight curvature and suggests almost linear growth for the northern bonito population (Fig. 13). The age-length data given by Campbell and Collins (1975) and Kuo (1970) are also quite different. The lengths at the different ages as given by Campbell and Collins are larger for all the ages than those given by Kuo.

The maximum size of $S$. chiliensis in the Southern Hemisphere is not well defined. Barrett (1971) sampled the fish landed in the Chilean fishery and noted that the maximum size of fish landed was $74 \mathrm{~cm}$. In an earlier study Buen (1958) found fish as large as $79 \mathrm{~cm}$. Mann (1954) stated that Chilean bonito grows larger than 80 $\mathrm{cm}$.

\section{Sarda orientalis}

Very little information is available on the age and growth of $S$. orientalis. Yabe et al. (1953) presented data on the mean lengths of six samples of $S$. orientalis ranging in length from 161 to $348 \mathrm{~mm}$ that were sampled at Aburatsu, Japan, over an irregular period from 26 August to 17 October 1950 (Table 17). The mean lengths of fish from the six samples were plotted against sampling date, and a straight line was drawn by eye through the data points (Fig. 14). If the line is a reasonable representation of the growth of $S$. orientalis between 161 and $348 \mathrm{~mm}$, it indicates a mean growth of about $2.6 \mathrm{~mm} /$ day. Harada et al. (1974) made observations on the growth of larval and juvenile $S$. orientalis in artificial fertilization experiments. They determined that the fertilized eggs hatched in about $50 \mathrm{~h}$ in water temperature ranging from $20^{\circ}$ to $24^{\circ} \mathrm{C}$ and that the newly hatched larvae were $4.1-4.3 \mathrm{~mm}$ in total length. The larvae grew to $14 \mathrm{~mm}$ in total length 
Table 17.-Lengths of Sarda orientalis landed at Aburatsu, Japan in 1950. (From Yabe et al. 1953, table 11.)

\begin{tabular}{lccc}
\hline & $\begin{array}{c}\text { No. of } \\
\text { fish }\end{array}$ & \multicolumn{2}{c}{ Body length $(\mathrm{mm})$} \\
\cline { 3 - 4 } Date & 17 & Range & Mean \\
Aug. 26 & 2 & $205-221$ & 214 \\
Sept. 1 & 3 & $241-249$ & 245 \\
Sept. 2 & 5 & $233-243$ & 239 \\
Sept. 8 & 10 & $161-270$ & 239 \\
Sept. 9 & 5 & $254-277$ & 263 \\
Oct. 17 & & $333-348$ & 339 \\
\hline
\end{tabular}

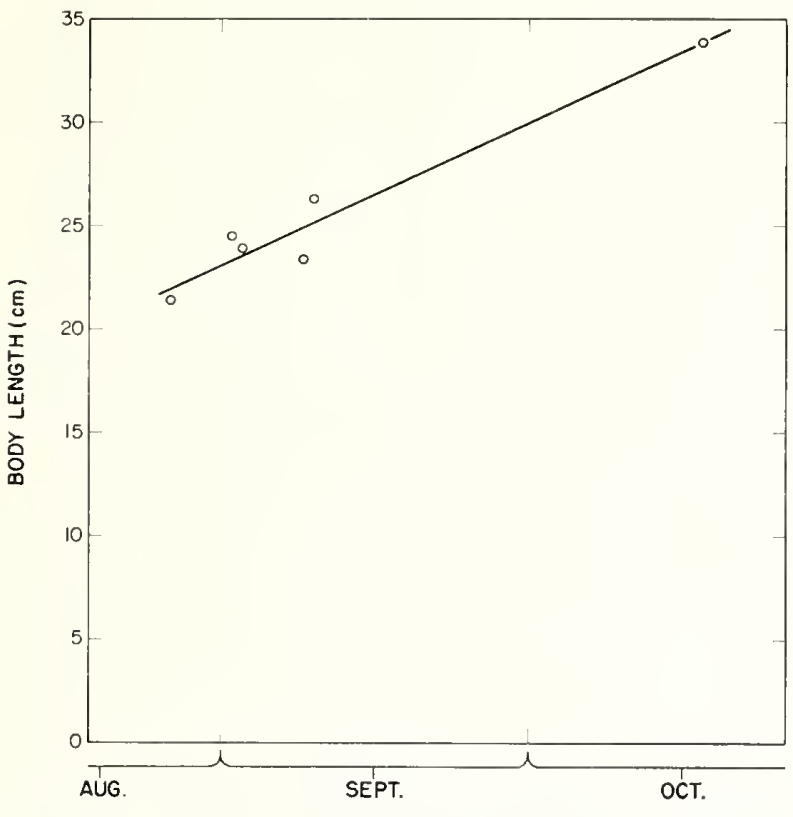

Figure 14.-Growth of juvenile Sarda orientalis in Japanese waters. (Data from Yabe et al. 1953.)

in 10 days, to $74 \mathrm{~mm}$ in 20 days, to $106 \mathrm{~mm}$ in 30 days, to $219 \mathrm{~mm}$ in 42 days, and to $290 \mathrm{~mm}$ in 99 days after hatching. This growth rate represented the fastest growth under the conditions provided in the experiment. The growth rate of larval and juvenile $S$. orientalis indicated by these experiments was about 2.9 $\mathrm{mm}$ /day during the 99-day period and compares favorably with that suggested by the data presented by Yabe et al. (1953). Harada et al. (1973) presented some data on the growth of $S$. orientalis kept in artificial enclosures. Thirty-three $S$. orientalis $40 \mathrm{~cm}$ long and $675 \mathrm{~g}$ in weight grew to $50 \mathrm{~cm}$ and $1,500 \mathrm{~g}$ in about $4 \mathrm{mo}$.

Regarding the maximum size of $S$. orientalis in the Indian Ocean, the large specimens off the southwest coast of India are generally less than $70 \mathrm{~mm}$ long (Silas 1964). Smith (1949) stated, however, that $S$. chiliensis (= S. orientalis) grows to at least $101.6 \mathrm{~cm}$ (40 in). In Japanese waters $S$. orientalis grows to about $80 \mathrm{~cm}$ and $1.5-3.0 \mathrm{~kg}$ (Kishinouye 1923).

\section{Sarda sarda}

Various investigators have presented monthly length data for young $S$. sarda from the Black Sea (Table 18).
Table 18.-Monthly length data for Sarda sarda from the Black Sea. (Data from Demir 1963.) (Note: The author did not define the length dimension.)

\begin{tabular}{lcccc}
\hline \multicolumn{1}{c}{ Author } & July & Aug. & Sept. & Oct. \\
\hline & $\ldots$ & & & \\
& - & & Length $(\mathrm{cm})$ & $\ldots$ \\
Zusser (1954) & - & $19-27$ & $27-29.5$ & $25-36$ \\
Tkacheva (1958) & - & $21-33$ & $27-36$ & $36-40$ \\
Mayorova and Tkacheva (1959) & - & $21-33$ & $27-37$ & $36-41$ \\
Demir (1963) & $6-16$ & $12-32$ & $25-38$ & $33-42$ \\
\hline
\end{tabular}

The data were given as the ranges of lengths sampled during monthly periods, and the midpoints of the length ranges were plotted to represent the growth of $3-42 \mathrm{~cm} \mathrm{~S}$. sarda in the Black Sea (Fig. 15). As would be expected, there is some variation in the data presented by the various investigators, but the variation was relatively small. In gross terms these data suggest that $S$. sarda grew about $252 \mathrm{~mm}$ in 90 days $(7.5-11 \mathrm{~cm}$ in July to 30.5 $38.5 \mathrm{~cm}$ in October) or at a growth rate of $2.8 \mathrm{~cm} /$ day.

Demir (1963) summarized the age-length relation of $S$. sarda determined by various authors (Table 19). Subsequent to the publication of Demir's paper, Kutaygil (1967) published some data on age-length determinations on S. sarda (Table 20). Kutaygil used otoliths to age the fish and also back-calculated the lengths of the fish at various ages. He noted that bonito from different year classes had different growth rates.

Zusser (1954), in contrast to the other investigators, gave age-length relations for fish up to $9 \mathrm{yr}$ of age. Demir (1963), however, remarked that the age-length relations given by Zusser were probably erroneous. Although several age-length relations for $S$, sarda are available, as far as it is known, no one has tried to fit a growth curve to these data.

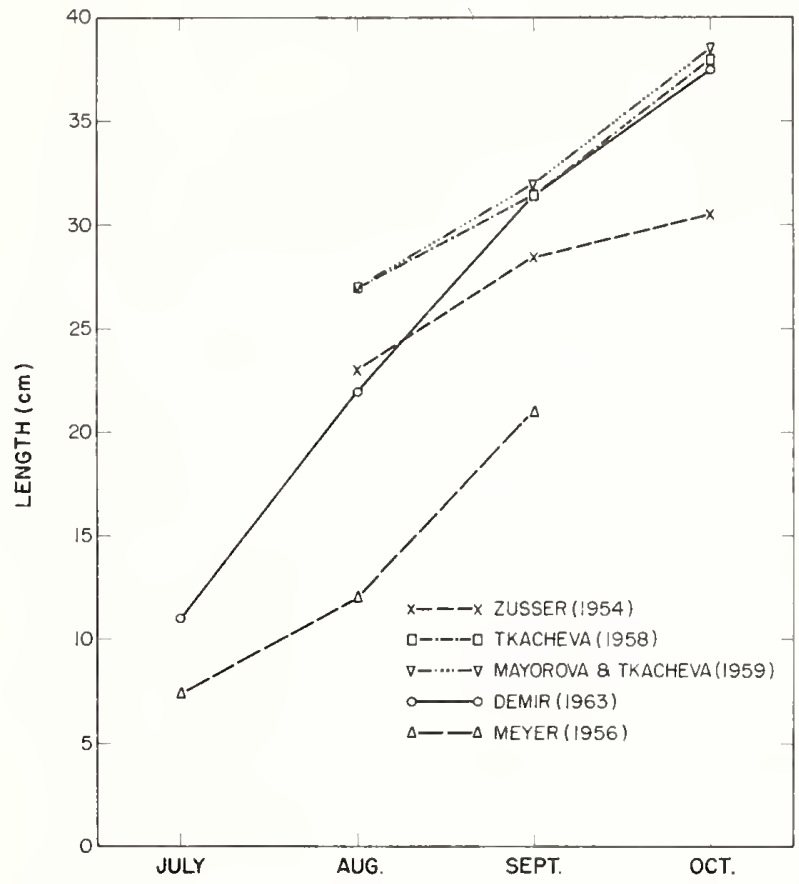

Figure 15.-Growth of juvenile Sarda sarda in the Black Sea. 
Table 19.-Age-length relation in Sarda sarda. (From Demir 1963, table 4.) (Note: The length dimension was not defined by the author.)

\begin{tabular}{|c|c|c|c|c|c|c|c|c|c|}
\hline \multirow[b]{2}{*}{ Author } & \multicolumn{8}{|c|}{ Age } & \multirow[b]{2}{*}{9} \\
\hline & 1 & 2 & 3 & 4 & 5 & 6 & 7 & 8 & \\
\hline & .... & $\ldots$ & $\ldots$ & - Len & $h(\mathrm{~cm})$ & & & & \\
\hline \multirow{2}{*}{ Zusser (1954) } & $25-37$ & $33-50$ & $42-54$ & $50-62$ & $56-67$ & $60-70$ & $63-76$ & $70-78$ & $74-85$ \\
\hline & 31.5 & 41.5 & 48.8 & 56.2 & 61.2 & 66.5 & 69.5 & 73.5 & 76.2 \\
\hline Nümann (1955) & $38-41$ & $53-57$ & $60-64$ & - & - & - & - & - & - \\
\hline Nikolskii (1957) & 35.3 & 55.1 & 64.2 & 72.5 & - & - & - & - & - \\
\hline Türgan (1958) & $30-40$ & $50-55$ & $55-60$ & $60-65$ & - & - & - & - & - \\
\hline Nikolov (1960) & 38.85 & 52.6 & 60 & 67 & $(74-75)$ & - & - & - & - \\
\hline
\end{tabular}

Table 20.-Calculated lengths for each age of Sarda sarda. (From Kutaygil 1967, table 26.) (Note: The author did not define the length dimension.)

\begin{tabular}{|c|c|c|c|c|c|c|c|}
\hline \multirow[b]{2}{*}{ Sample } & & & \multirow{2}{*}{$\begin{array}{c}\text { No. of } \\
\text { fish }\end{array}$} & \multicolumn{4}{|c|}{ Age } \\
\hline & & & & 1 & 2 & 3 & 4 \\
\hline \multirow[t]{5}{*}{1957} & II & (1955) & 7 & 44.0 & 59.1 & - & - \\
\hline & III & (1954) & 22 & 45.4 & 57.9 & 64.8 & - \\
\hline & IV & (1953) & 4 & 47.6 & 59.2 & 64.5 & 68.7 \\
\hline & Grand & mean $=$ & & 45.1 & 58.3 & 64.9 & \\
\hline & & $N=$ & & 33 & 33 & 26 & \\
\hline Jan. 1958 & IV & (1954) & 5 & 42.9 & 53.3 & 60.6 & 64.2 \\
\hline Feb. 1958 & IV & (1954) & 18 & 41.1 & 52.9 & 59.2 & 63.8 \\
\hline
\end{tabular}

The largest $S$. sarda is about $85 \mathrm{~cm}$ in the Black Sea. Of S. sarda in the western Atlantic, Bigelow and Schroeder (1953) stated that they grow to about $91.4 \mathrm{~cm}$ (36 in) and 4.5-5.4 kg (10-12 lb). Hammond and Cupka (1975) noted that $S$. sarda seldom exceeds $6.8 \mathrm{~kg}$ (15 lb).

\subsection{Behavior}

\subsection{Migrations and local movements}

See also section 5.3 .

The seasonal migrations of $S$. sarda from the Aegean Sea through the Sea of Marmara to the Black Sea have been well documented. The migration routes were presumably determined by the development of the fisheries in these areas and were verified by tagging experiments (Demir 1963). The migration from the Aegean Sea to the Black Sea starts toward the end of April and lasts to the beginning of June or later. The return migration from the Black Sea to the Aegean Sea usually starts in September and lasts to the end of November. Some of the bonito schools returning from the Black Sea may stay in the Sea of Marmara but others continue on to the Aegean Sea.

The S. sarda in the Adriatic Sea apparently make a north-south migration within that sea down to around the Greek islands (Belloc 1954). The bonitos leave the upper Adriatic in November-December and travel along both shores of the Adriatic, arriving in Greek waters in February-March. The return migration starts around August. In addition, there apparently are schools of bonito that remain the whole year round in Greek waters and in waters along the east coast of Sicily.

The relation of the bonitos in the Aegean Sea-Sea of
Marmara-Black Sea complex with the Adriatic Sea bonito and with the bonitos in the other parts of the Mediterranean is not clear. Turkish investigators imply that the stock in the Aegean Sea-Sea of Marmara-Black Sea complex originates in the Aegean Sea and the Sea of Marmara (Demir 1957) and remain within this complex.

In the eastern Pacific, over 11,200 S. c. lineolata have been tagged and released since 1968 along the coast from Monterey Bay, Calif., to Cape San Lazaro, Baja California (Collins and MacCall 1977). Recoveries of tagged fish have indicated that they move randomly in local California waters, although there was a definite movement down the southern California coast in the winter and a northward movement in the late summer and fall, apparently in response to changes in sea temperature. Their tagging study also indicated that heated water discharges from coastal electric generating stations strongly influence the migration of young $S$. c. lineolata. Fish tagged in heated water plumes either remained in the area of the discharge or tended to migrate to another heated discharge area.

\subsection{Schooling}

All species of Sarda generally appear to be schooling fish. Sarda australis commonly occur in schools in inshore coastal waters of Queensland, Australia (Grant 1972). Frey (1971) stated that the $S$. chiliensis of the Northern Hemisphere is a pelagic schooling fish. Tominaga (1943), however, observed that $S$. orientalis in Japanese waters do not aggregate densely, rarely come to the surface of the sea, and always swim around reefs or near a cape where the current is strong, and that they never go out to the high seas. Conflicting observations are available on schooling of $S$. orientalis in the Indian Ocean. Silas (1963) stated that schools of adults and young appear along the southwest coast of India. Sivasubramaniam (1969), however, noted that $S$. orientalis are very seldom seen in surface schools of mixed tunas and when they are caught from mixed schools, the catch never exceeds six fish. All of the observations on $S$. sarda indicate it is a schooling fish. Demir (1963) stated that $S$. sarda gathers in dense schools of many thousands of fish of about the same size. Sarda sarda in the western Atlantic is a schooling fish, traveling in large aggregations. It is usually found at the surface, although occasionally it is caught near the bottom (Idyll and de 
Sylva 1963). Of $S$. sarda that occurs in the Gulf of Maine, Bigelow and Schroeder (1953) wrote, "The bonito is a strong, swift, predaceous inhabitant of the open sea and like its tribe travels in schools."

\subsection{Responses to stimuli}

A detailed, systematic study on the behavior of captive $S$. c. lineolata in a large fish tank at Marineland of the Pacific, Palos Verdes, Calif., was made by Magnuson and Prescott (1966). The courtship and spawning behavior of $S$. c. lineolata, as reported by Magnuson and Prescott, was discussed earlier in sections 3.11 and 3.13. Further results of their observations are detailed below.

About $25 \mathrm{~S}$. c. lineolata out of 60 that were caught near Marineland of the Pacific became established in the tank and were used in the observational program. Of the 25 survivors, 10 fish lived for 38 mo in captivity. The tank used was part of a public display and contained more than 800 other fishes of over 40 species. Part of the daily routine included five 15 -min shows in which a diver entered the tank to feed the fish. Magnuson and Prescott noted that the $S$. c. lineolata "appeared habituated to show announcements and background music as well as to sounds made by tapping on the tank windows and sides." These observations indicate that $S$. c. lineolata are able to adapt to various environmental conditions.

In the Marineland of the Pacific tank, S. c. lineolata swam continuously against the current averaging 88.2 $\mathrm{cm} / \mathrm{s}$ at a tail-beat frequency of 1.42 beats $/ \mathrm{s}$ when not feeding or courting. Sarda c. lineolata apparently are less powerful swimmers than skipjack and yellowfin tunas. In fish about the same length (bonito, $57 \mathrm{~cm}$; skipjack tuna, $57 \mathrm{~cm}$; yellowfin tuna, $52 \mathrm{~cm}$ ) Magnuson and Prescott noted that at four tail beats/s S. c. lineolata traveled only $170 \mathrm{~cm} / \mathrm{s}$ whereas Katsuwonus pelamis averaged 230 $\mathrm{cm} / \mathrm{s}$ and $T$. albacares averaged $240 \mathrm{~cm} / \mathrm{s}$.

Magnuson and Prescott observed nine miscellaneous behavior patterns in S. c. lineolata: mouth closure (long), mouth closure (short), snap, yawn, quick swim, lean, bend, jerk, and defecation. They discussed in detail the possible functions of all these miscellaneous behavior patterns. They hypothesized that mouth closure (long) movements could have been associated with olfaction or gill ventilation; snaps following a yawn or a quick swim with a drinking movement; leans may have a function as a social releaser in schooling; and bends and jerks may be associated with food passing through the alimentary canal.

No such detailed behavioral observations have been

Table 21.-Sex ratio of Sarda sarda landed in Spain. (From Rodríguez-Roda 1966.)

\begin{tabular}{lllccc}
\hline Year & Month & Port & Males & Females & $\begin{array}{c}\text { Ratio } \\
\text { (Male:Female) }\end{array}$ \\
\hline 1963 & June & Tarifa & 17 & 18 & $1: 1.06$ \\
1964 & May & Barbate & 57 & 20 & $1: 0.35$ \\
1964 & June & Barbate & 25 & 24 & $1: 0.96$ \\
1964 & July & Barbate & 18 & 24 & $1: 1.33$ \\
\hline
\end{tabular}

made on other species of Sarda. Inoue et al. (1967) were able to maintain $S$. orientalis up to $438 \mathrm{~h}$ in a pool. Inoue et al. (1970) determined that $S$. orientalis was negatively phototactic to both sunlight and artificial light. The swimming speeds of the fish (size not given) ranged from 0.3 to $0.56 \mathrm{~m} / \mathrm{s}$.

\section{POPULATION}

\subsection{Structure}

4.11 Sex ratio

Sarda australis

No information.

$$
\text { Sarda chiliensis }
$$

Kuo (1970) obtained sex ratio data on S. c. lineolata that were caught from San Diego waters during a 1-yr period between 1964 and 1968. The percentage of females in the monthly samples varied from 37.5 to $70.3 \%$ and averaged $49.9 \%$ for the year. He found that the monthly sex ratios did not differ significantly from 1:1 except for the sample from the month of May.

The percentage of female S. c. chiliensis from eight samples of 100 bonito each obtained from the commercial catch landed at Iquique, Chile, varied from 47 to $65 \%$ between September 1968 and October 1969 (Barrett 1971). Barrett noted that more females were present in the catch during September-October spawning season, but stated that more data were needed to verify this observation.

\section{Sarda orientalis}

No information.

\section{Sarda sarda}

Rodríguez-Roda (1966) determined the sex ratio of four samples of $S$. sarda landed at the ports of Barbate and Tarifa, Spain (Table 21), in 1963 and 1964. The females in the samples ranged from 26 to $57.1 \%$. Postel (1955b) presented data on the monthly sex ratio of $S$. sarda from the eastern tropical Atlantic (Table 22). In the Gulf of Mexico a sample of $52 S$. sarda was composed of 31 males and 21 females (Boschung 1966).

\subsection{Age composition}

See section 4.13 .

\subsection{Size composition}

\section{Sarda australis}

There is no information on the size or age of the fish except for generalized observations. The species grows to 
Table 22.- Sex ratio of Sarda sarda from the eastern tropical Atlantic. (From Postel 1955b.)

\begin{tabular}{lrrc}
\hline \multicolumn{1}{c}{ Month } & Males & Females & $\begin{array}{c}\text { Ratio } \\
\text { (Male:Female) }\end{array}$ \\
\hline January & 13 & 12 & $1: 0.42$ \\
February & 38 & 30 & $1: 0.79$ \\
March & 65 & 70 & $1: 1.08$ \\
April & 142 & 115 & $1: 0.81$ \\
Mlay & 148 & 172 & $1: 1.16$ \\
June & 1 & 1 & $1: 1$ \\
July & - & - & - \\
August & - & - & - \\
September & - & 8 & $1: 2.67$ \\
October & 3 & 5 & $1: 0.71$ \\
November & 7 & 6 & $1: 1.20$ \\
December & 5 & 419 & $1: 0.99$ \\
Total & 422 & & \\
\hline
\end{tabular}

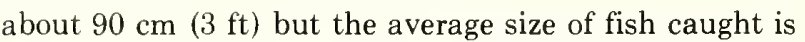
about 40 or $45 \mathrm{~cm}$ (16 or $18 \mathrm{in)} \mathrm{(Marshall} \mathrm{1964).} \mathrm{Grant}$ (1972) stated that the usual size taken is 1.8-2.3 kg (4-5 lb).

\section{Sarda chiliensis}

The length-frequency distribution of $S$. c. lineolata caught by sports fishermen from southern California waters shown in Figure 16 was prepared from data provided by C. M. Kuo and is based on part of the $S$. c. lineolata sample he used in his study (Kuo 1970). Kuo measured $929 \mathrm{~S}$. c. lineolata from southern California waters ranging in length from 331 to $750 \mathrm{~mm}$. Both the male and female length-frequency distributions were similar: a single prominent mode was present between 510 and $540 \mathrm{~mm}$.

MacCall et al. (1976) presented S. c. lineolata lengthfrequency data for the California commercial and partyboat fisheries in 1973 (Fig. 17). They stated that various segments of the fishery exploit different parts of the bonito population, which indicates an uneven geographical distribution of various age groups. It was indicated that, generally, the older fish were more available near Mexico and in offshore waters, although large fish were also taken in the fall off Santa Barbara. The partyboat fishery caught bonito $<60 \mathrm{~cm}$ but the long-range party boats fishing off Mexico took older fish. The commercial fishery took larger fish. It is of interest that the modal size taken by the party boats during the period 1964-68 was larger than that taken in 1973. Recruitment strength is highly variable in southern California waters, and because the party-boat fishery takes only young fish, the catch per effort and the size composition of the catch reflect this variability and may account for the difference in modal sizes ( MacCall ${ }^{5}$ ).

Barrett (1971) presented bonito length-frequency data from Chilean landings and noted that the larger bonito,

"Presently with Oceanic Institute, Makapuu Point, Waimanalo, HI 96795.

MacCall, A. D., California Department of Fish and Game, c/o National Marine Fisheries Service, La Jolla, CA 92038, pers. commun. February 1978.

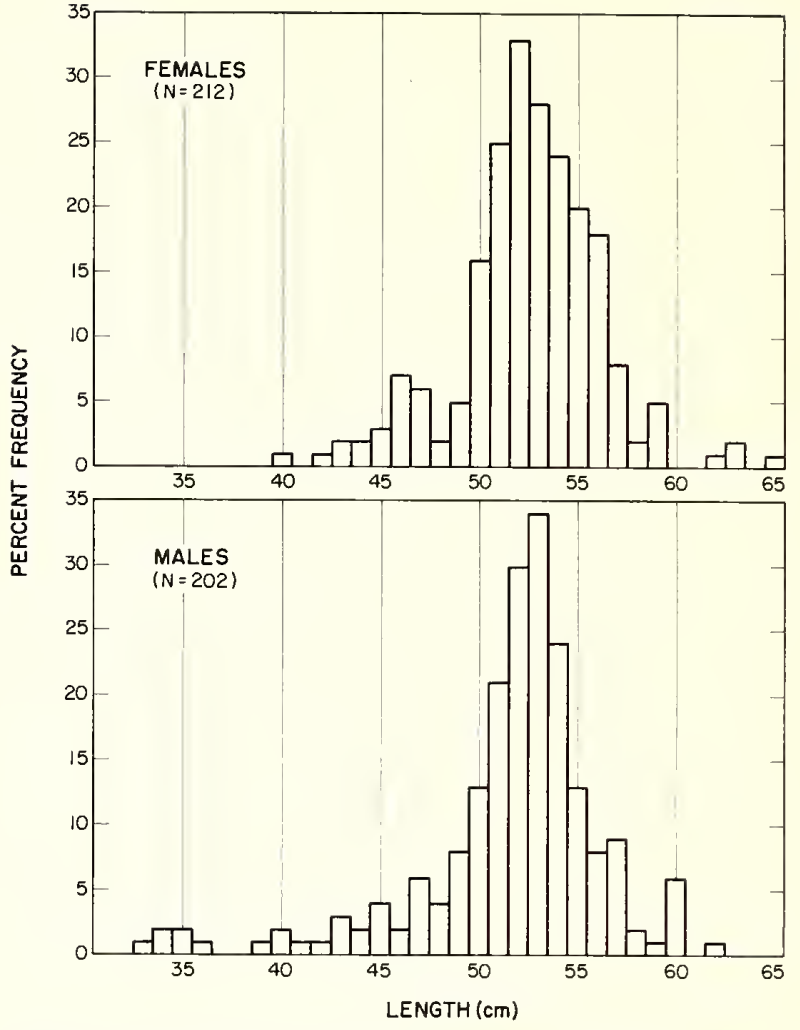

Figure 16.-Length-frequency distribution of Sarda chiliensis lineolata captured in the sport fishery in southern California.

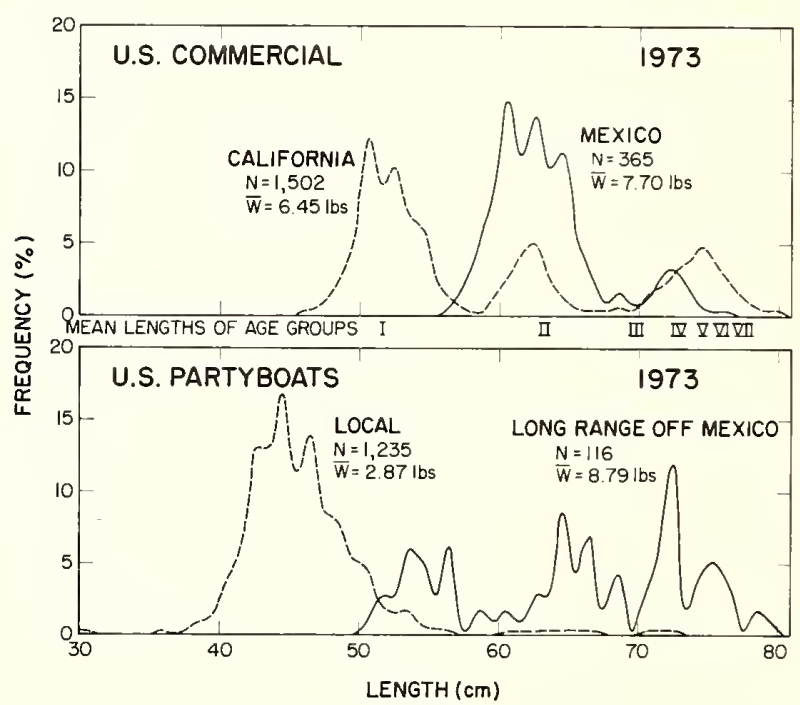

Figure 17.-Length-frequency distribution of Sarda chiliensis lineolata taken by the California commercial party-boat fisheries. (From MacCall et al. 1976, fig. 9.)

in about the $62 \mathrm{~cm}$ modal group, made up most of the catch in September-October 1968 (Fig. 18). Most of the bonito in the April, August, September, and October 1969 landings, however, were smaller, $48-52 \mathrm{~cm}$, and the larger fish were present only in July and August. Barrett 


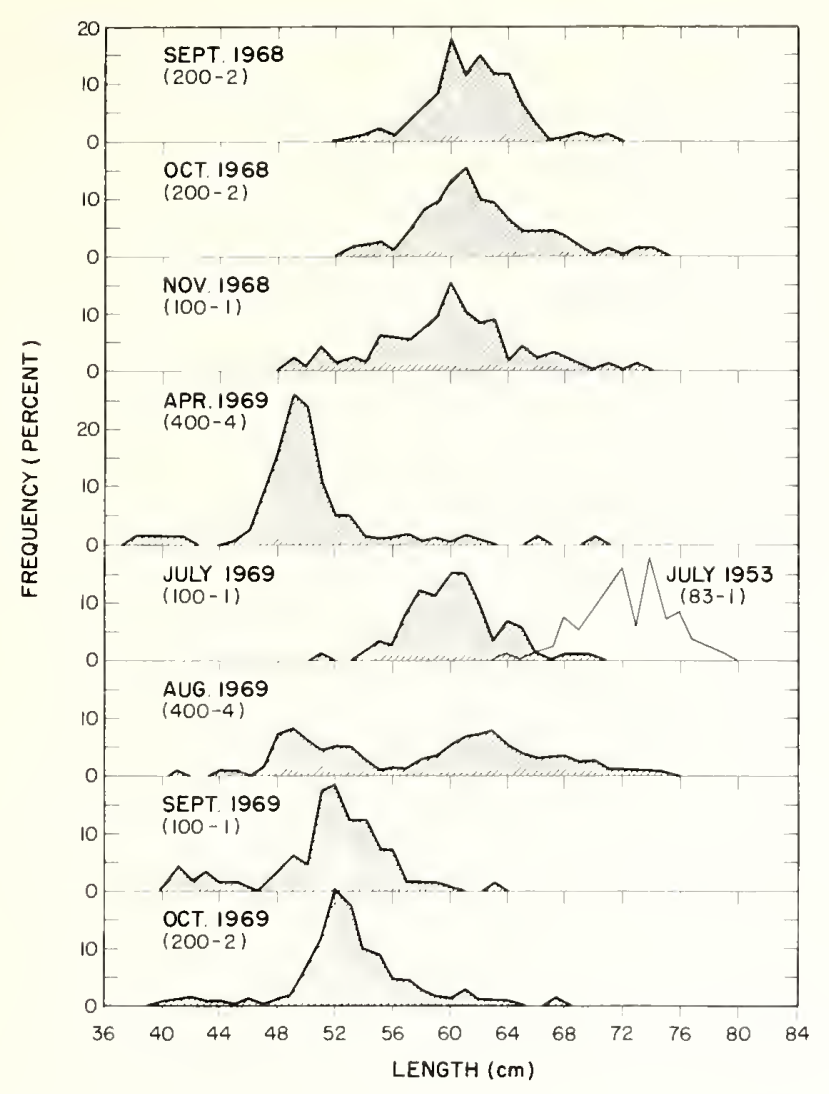

Figure 18.- Length-frequency distribution of Sarda chilienss chiliensis sampled from the commercial landings at Iquique, Chile, September 1968 to October 1969. Numerals in upper left corner of each panel indicate the month and year, number of fish, and number of samples. Unshaded distribution is from Buen (1958). (From Barrett 1971 , fig. 4.)

further noted that the preponderant $72-74 \mathrm{~cm}$ modal group in 1953 reported by Buen (1958) was almost absent in the 1968 and 1969 samples, which indicated that the older fish were no longer present in the fishery in 1968 and 1969.

Vildoso (1962) and Barrett (1971) determined lengthweight relationships for the southern $S$. chiliensis population and Campbell and Collins (1975) for the northern population (Table 23). In computing lengthweight relationships, many investigators use a logarithmic transformation to linearize the data. Beauchamp and Olson (1973) pointed out that a bias is inherent in this procedure because the largest values are compressed on the logarithmic scale and provided a procedure to correct for this bias. As they pointed out, corrections for this bias have been outlined in the past but seldom used in practice and it is most likely that the length-weight relationships in Table 23 have not been corrected for bias.

\section{Sarda orientalis}

Sivasubramaniam (1969) presented length data for $S$. orientalis from the Sri Lanka fishery (Fig. 19). The average size of adult $S$. orientalis taken off southwest India was about $45 \mathrm{~cm}$ (Silas 1963).

Data on the size composition of the stock of $S$. orientalis in Japanese waters are almost nonexistent. Yabe et al. (1953) presented measurement data on a small sample of $S$. orientalis landed at Aburatsu, Japan (Table 17).

Sivasubramaniam (1966) determined the lengthweight relationship for $S$. orientalis from the waters around Sri Lanka in the Indian Ocean (Table 23). The length-weight relationship is based on a sample of 25 fish, and although Sivasubramaniam did not give the size range of the fish, his figure 14 indicates that the fish ranged from about 24 to $51 \mathrm{~cm}$.

\section{Sarda sarda}

Black Sea landings of S. sarda in the spring of 1955 were dominated by a group of fish centered at a length of $45 \mathrm{~cm}$ (Fig. 20). In the spring of the subsequent $2 \mathrm{yr}$, the same group of fish $(1956,55 \mathrm{~cm} ; 1957,60 \mathrm{~cm} ; 1958,65$ $\mathrm{cm})$ dominated the catch. This group of fish was the result of a strong year-class that originated in 1954 (Mayorova and Tkacheva 1959). Artuz (1959) also noted the same phenomenon. He sampled the landings at the Istanbul fish market and found that 3-yr-old fish (1954

Table 23.- Predictive length-weight relationships, $W=a L_{\mathrm{b}}$, of Sarda. (Note: Various length and weight units were used in the original regressions, shown in the table. For ease in comparison, the constants werc converted where needed so that the regressions are in terms of weight in grams and length in centimcters.)

\begin{tabular}{|c|c|c|c|c|c|c|c|}
\hline \multirow[b]{2}{*}{ Species } & \multirow[b]{2}{*}{ Sex } & \multirow[b]{2}{*}{$\begin{array}{l}\text { No. of } \\
\text { fish }\end{array}$} & \multicolumn{2}{|c|}{ Size range of fish } & \multirow[b]{2}{*}{0} & \multirow[b]{2}{*}{$b$} & \multirow[b]{2}{*}{ Source } \\
\hline & & & $\begin{array}{l}\text { Weight } \\
\text { (g) }\end{array}$ & $\begin{array}{l}\text { Length } \\
(\mathrm{cm})\end{array}$ & & & \\
\hline S. c. chiliensis & - & 595 & - & $40-73$ & 0.0118 & 3.02 & Barrett (1971) \\
\hline S. orientalis & - & 25 & - & & 0.0152 & 2.958 & Sivasubramaniam (1966) \\
\hline S. sarda & - & 165 & - & $40-55.5$ & 0.0149 & 2.971925 & Rodriguez-Roda (1966) \\
\hline S. c. lineoloto & M & & & & 0.009088 & 3.09749 & $\begin{array}{l}\text { Campbell and Collins } \\
\text { (1975) }\end{array}$ \\
\hline S. c. lineoloto & $\mathrm{F}$ & 2,824 & $200-7,675$ & $29-77$ & 0.009611 & 3.08338 & $\begin{array}{l}\text { Campbell and Collins } \\
\text { (1975) }\end{array}$ \\
\hline S. c. lineolata & $\begin{array}{c}\text { Sexes com- } \\
\text { bined }\end{array}$ & & & & 0.009376 & 3.08962 & $\begin{array}{l}\text { Campbell and Collins } \\
\text { (1975) }\end{array}$ \\
\hline S. c. chiliensis & M & 565 & - & - & 0.006491 & 3.19 & Vildoso (1962) \\
\hline S. c. chiliensis & $\mathrm{F}$ & 513 & - & - & 0.006311 & 3.19 & Vildoso $(1962)$ \\
\hline
\end{tabular}




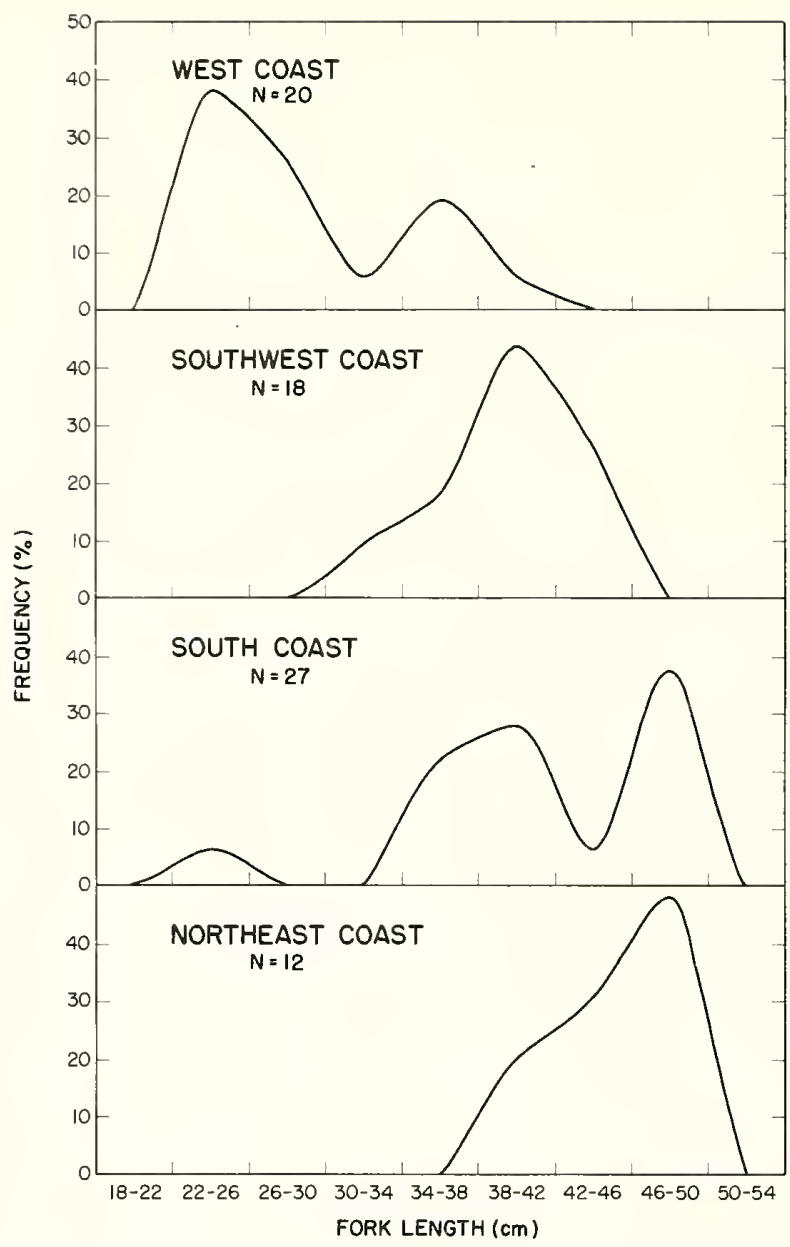

Figure 19.-Length-frequency distribution of Sarda orientalis around Sri Lanka (Ceylon) (1967-68). (From Sivasubramaniam 1969, fig. 1.)

year class) dominated the landings in May 1957. His sample showed that the May 1957 landings were composed of $10.5 \%$ age I fish (1956 year class), $28.7 \%$ age II fish (1955 year class), $53.2 \%$ age III fish (1954 year class), and $7.6 \%$ age IV fish (1953 year class). Mayorova and Tkacheva (1959) noted that a rich year class in 1938 also dominated the fishery in the Black Sea from 1938 to 1945.

The 1963 length-frequency distribution of $S$. sarda landed at Barbate and Tarifa, Spain, showed a strong mode centered at around $41 \mathrm{~cm}$ and lesser modes between 49 and $59 \mathrm{~cm}$ and 59 and $69 \mathrm{~cm}$ (Fig. 21). The 1964 sample had only two modes: one at about $43 \mathrm{~cm}$ and the other at about $51 \mathrm{~cm}$. Rodríguez-Roda (1966) also presented a weight-frequency distribution of $S$. sarda (Fig. 22), which showed only two modes for the 1963 sample and only one well-defined mode for the 1964 sample. The 1964 data were also summarized by month (Fig. 23). The length-frequency distribution showed two well-defined modes in May, June, and July whereas the weight-frequency distribution showed only a single mode during those months. It is of interest that the relative propor-

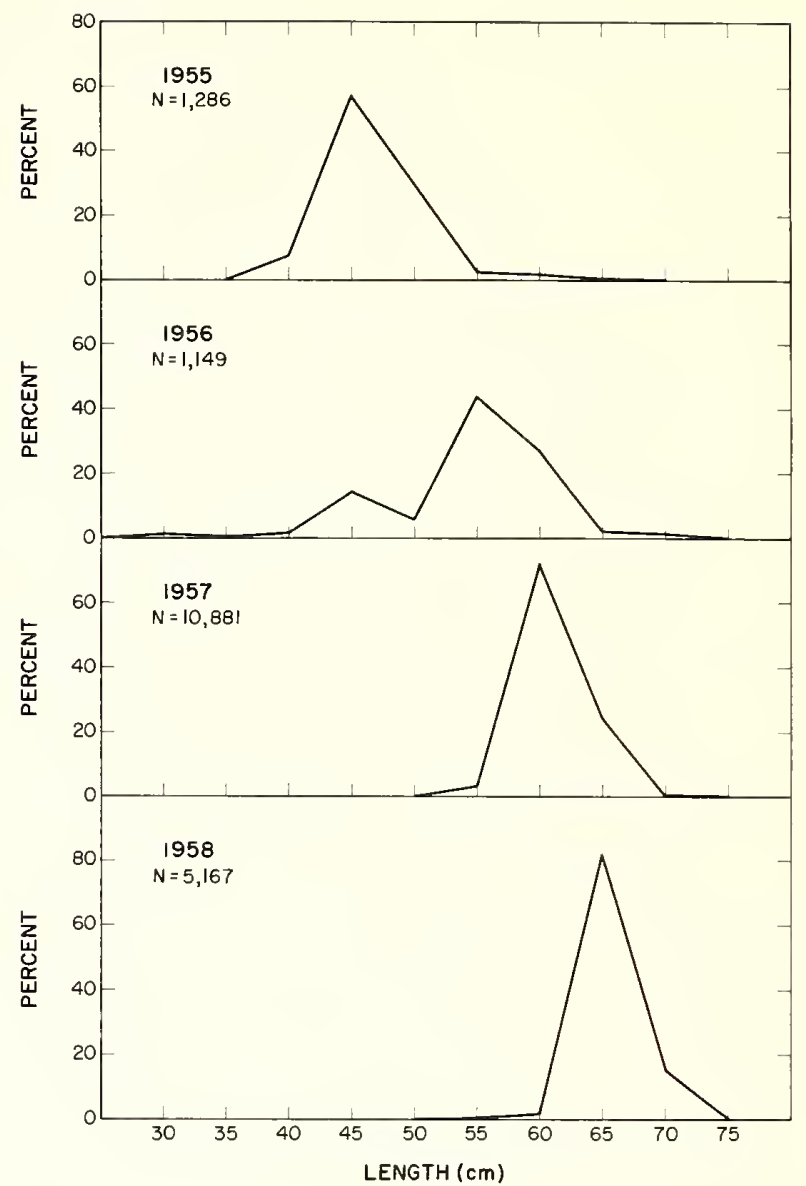

Figure 20.-Length-frequency distribution of Sarda sarda in the Black Sea, spring 1955-58. (Data from Mayorova and Tkacheva 1959, table 1.)

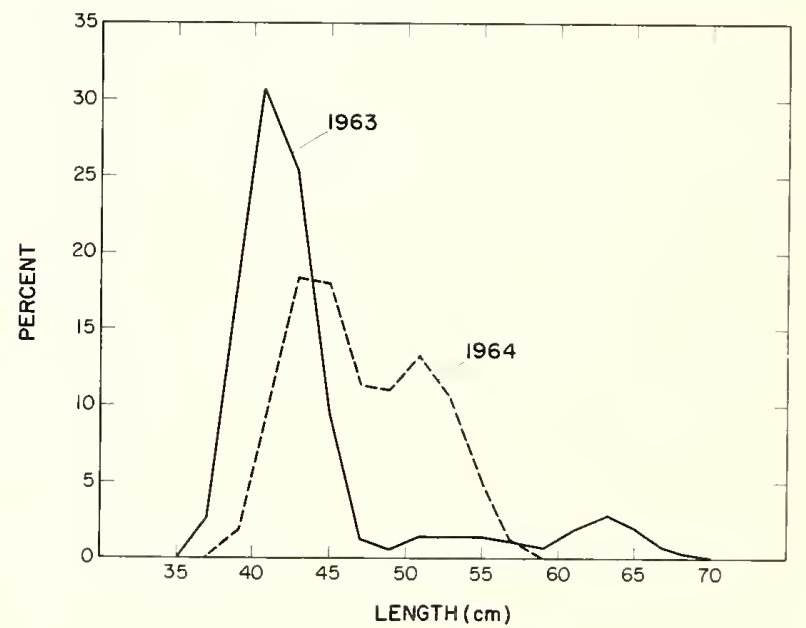

Figure 21.-Sarda sarda length-frequency distribution, Barbate and Tarifa, Spain. Data smoothed by formula $f_{11}=\frac{f_{n}+2 f_{n}+f_{11-1}}{4}$.
(From Rodriguez-Roda 1966, fig. 11.)

tion of fish in the larger mode in the length-frequency distribution appeared to decrease from May to July. The 


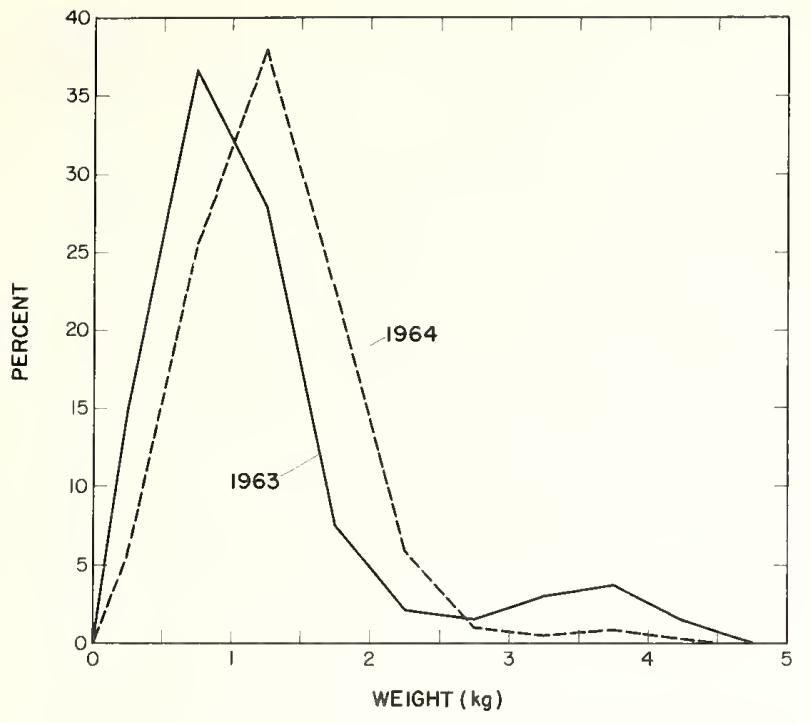

Figure 22.-Sarda sarda weight-frequency distribution, Barbate and Tarifa, Spain. Data smoothed by formula $f_{\mathrm{n}}=\frac{f_{\mathrm{n}-1}+2 f_{\mathrm{n}}+f_{\mathrm{n}+1}}{4}$. (From Rodriguez-Roda 1966, fig. 14.)

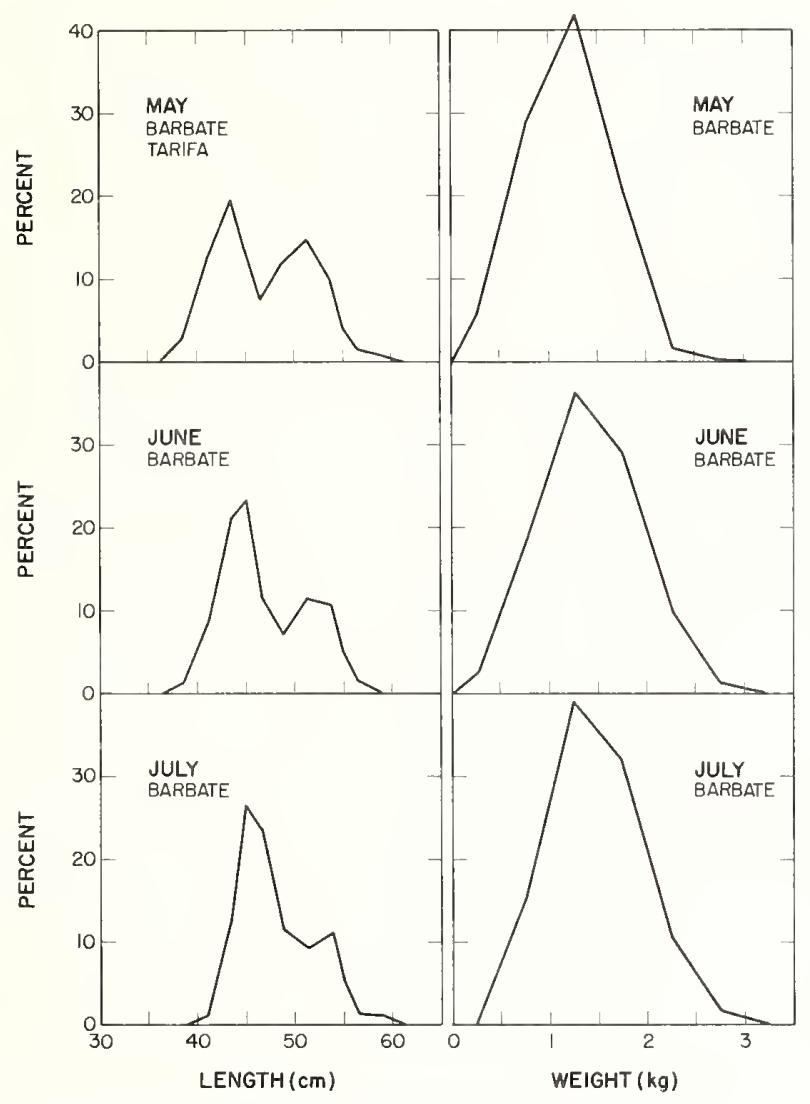

Figure 23.--Sarda sarda length (Barbate and Tarifa) and weight (Barbate) frequency distribution 1964. (From Rodriguez-Roda 1966, figs. $12,15$.

length-frequency distribution of male and female $S$. sarda were similar except that the modes were displaced (Fig. 24).

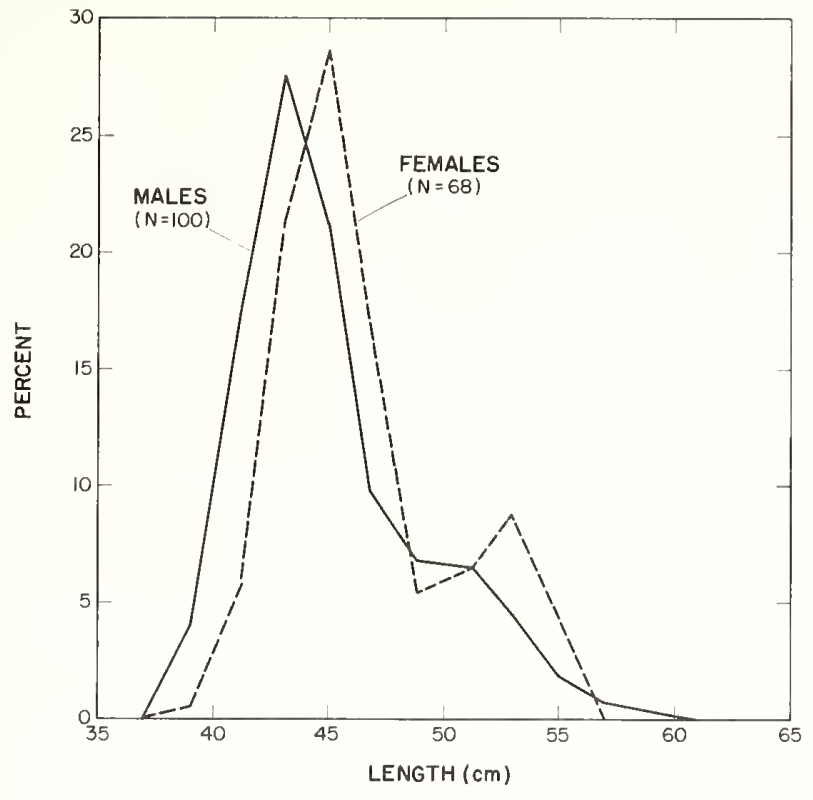

Figure 24.-Sarda sarda length-frequency distribution, Barbate and Tarifa, Spain, arranged by sex. (From Rodriguez-Roda 1966, fig. 13.)

Postel (1955a) presented data on the maximum size of $S$. sarda sampled in monthly periods in the eastern tropical Atlantic. The maximum lengths ranged from 450 to $690 \mathrm{~mm}$ for the males and 443 to $714 \mathrm{~mm}$ for the females.

Rodríguez-Roda (1966) computed the length-weight relation of $S$. sarda landed at the southern Spanish port of Barbate (Table 23).

\subsection{Subpopulations}

It appears that the $S$. c. lineolata found off northern Mexico and southern California comprise a single homogeneous stock. Tagging experiments conducted by the California Department of Fish and Game indicate that the bonito does not make long migrations. Although some tagged fish have traveled as far as 600 miles, most of the tagged fish have been recaptured in the vicinity of release; fish that traveled long distances moved from Mexico to southern California waters in the summer and back to Mexican waters again in the winter (Frey 1971; Collins and MacCall 1977).

From all indications it appears that the Northern and Southern Hemisphere populations of $S$. chiliensis are completely separate with little or no interchange. They are geographically separated from each other and there are certain meristic and morphological differences between the two populations. For example, the Northern Hemisphere population of bonito averages more vertebrae than the Southern Hemisphere population (Vildoso 1963b; Kuo 1970; Collette and Chao 1975).

Some preliminary work has been done on S. chiliensis to determine if protein differences attributable to genetic variation could be useful in identifying population units. Barrett and Williams (1967) experimented with 
gel-electrophoresis of the soluble eye lens proteins of bonito in an attempt to find such genetically controlled differences. They did find polymorphisms of the soluble lens proteins for the bonito. They also calculated the gene frequencies together with their expected distributions and found conformity to the Hardy-Weinberg principles. However, Barrett and Williams also found that the distributions of the apparent phenotypes were related to the lengths of the bonito. They concluded, therefore, that ontogenetic factors caused the observed polymorphism and that gel-electrophoresis of the soluble eye lens proteins, under the conditions used in their experiment, was not a useful technique in differentiating population units of bonito.

Smith (1971) examined the electrophoretic patterns of nuclear lens proteins from S. c. lineolata and also found polymorphism in the protein patterns. He suggested that there could be another explanation, as stated by Eckroat and Wright (1969), for the observed distribution of phenotypes than that suggested by Barrett and Williams (1967). Eckroat and Wright (1969) suggested that two separate fractions inherited as present/absence differences could account for the distribution of the three phenotypes observed by Barrett and Williams (1967). If this situation obtained, then the distribution of the observed phenotypes would indicate that there were two different breeding populations represented in the catches sampled.

It is not clear whether the stocks of $S$. c. chiliensis off Peru and Chile are independent of each other or whether they form a single homogeneous population. The center of bonito abundance off Peru is from Chimbote to Pisco (Ancieta 1963), which is centrally located between the north and south borders of Peru. The center of abundance off Chile is closer to the northern boundary of Chile near Arica, Iquique, and Antofagasta (Barrett 1971). In other words, the stocks of S. c. chiliensis off the

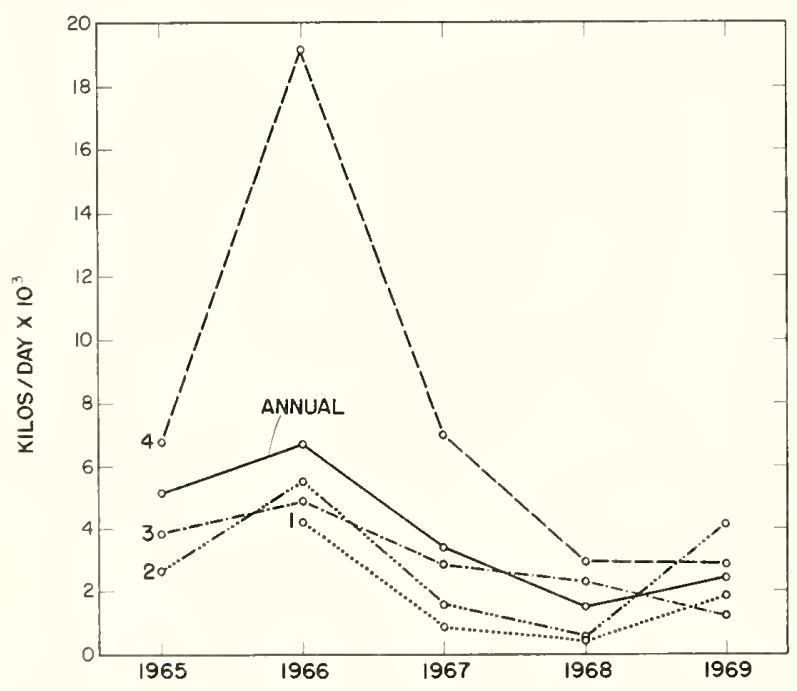

Figure 25.-Apparent abundance of Sarda chiliensis chiliensis, for individual quarters and years, by year, from data for the bonito vessels. (From Barrett 1971, fig. 8.) coasts of Chile and Peru are at least contiguous with each other. In his attempts at determining a stock production model for the Chilean bonito, however, Barrett (1971) apparently considered only the Chilean stock. He listed as one of his recommendations, however, that future studies should include a "determination of relation, if any, with the Peruvian fishery for bonito."

No information is available on subpopulations of $S$. orientalis and S. sarda. The coastal distribution of all the species of Sarda, the migration patterns of $S$. c. lineolata, and the disjunct distribution of S. orientalis and $S$. sarda suggest the existence of discrete subpopulations. Based on scattered anatomical and meristic data, there appeared to be no difference in the populations of $S$. orientalis, although some morphometric differences were found in samples from Japan and the eastern Pacific. Similarly, a geographical comparison of S. sarda samples showed no conclusive differences among the various populations (Collette and Chao 1975).

\subsection{Abundance and density}

\section{Sarda australis}

Marshall (1964) said that S. australis, along the coasts of Queensland and New South Wales, are found in "great schools throughout the year." Grant (1972) stated that this species occurs in schools in Queensland waters especially during the winter months.

\section{Sarda chiliensis}

In the Chilean bonito fishery Barrett (1971) examined the relations among fishing effort, yield, and apparent abundance for the period from January 1965 to December 1969. Barrett recognized three different types of vessels, according to species objective, that fish bonito in the Chilean fishery: the anchovy, bonito, and tuna vessels. As the name implies, the anchovy and tuna vessels fished for bonito when anchovy and tunas, respectively, became less available and bonito more available. The bonito vessels fished primarily for bonito, although they did also capture other species. Barrett used the data from the bonito vessels for his analysis. The data for the entire monitored fleet, however, showed the same trends as for the bonito fleet after they were standardized to that of the bonito vessels. He noted a steep downward trend in total catch, an upward trend in relative fishing intensity, and a corresponding decline in apparent abundance in the fishery (Figs. 25, 26, 27). The trend appeared to level off in 1969. Barrett stated that the decline probably resulted from the effects of the fishery and not from fishery-independent factors.

MacCall et al. (1976) related the indices of abundance of the Northern Hemisphere S. chiliensis obtained by Squire (1972) on aerial surveys with catch per unit of effort (CPUE), in terms of catch in numbers of fish per angler, for the California party-boat fishery. MacCall et al. assumed that the aerial survey concentrated on the commercial fishing grounds because the surveys were 

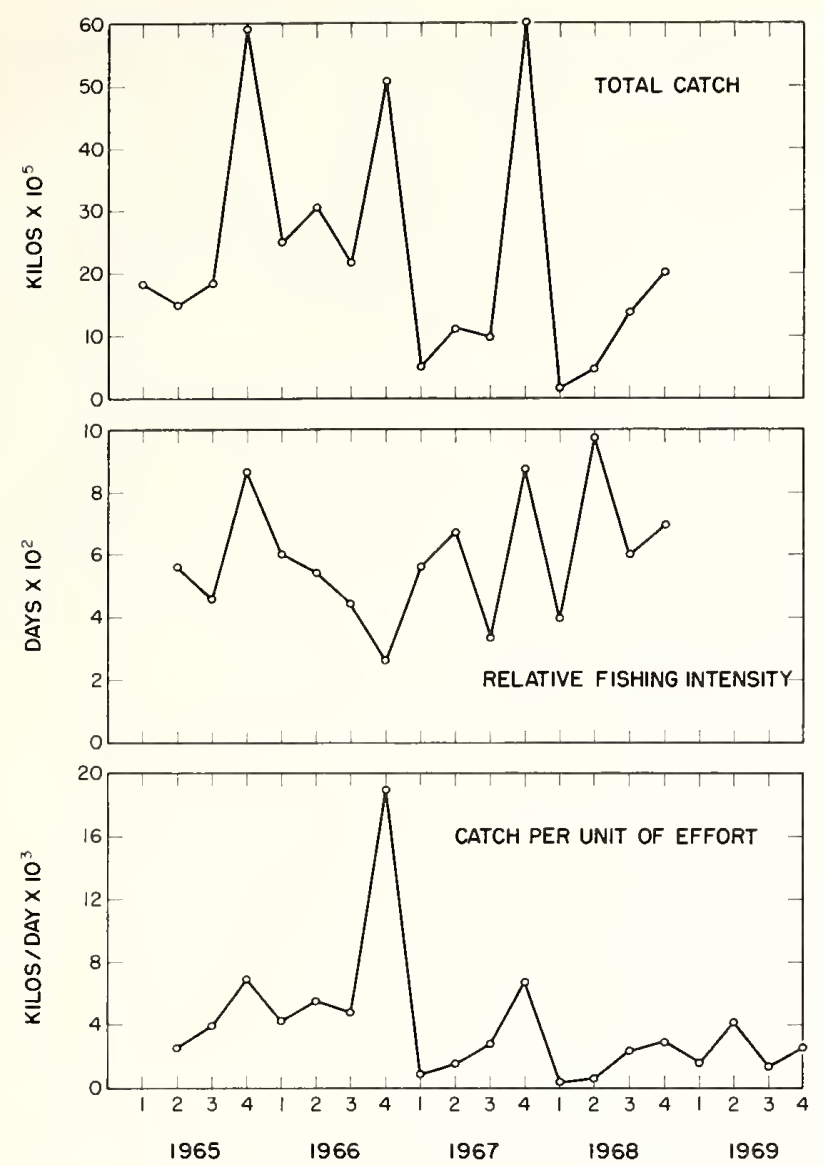

Figure 26.-Sarda chiliensis chiliensis total catch, and relative fishing intensity and apparent abundance (from data for the bonito vessels), quarterly from 1965 to 1969 . Relative fishing intensity for 1969 is not shown because data for total catch in 1969 were not available. (From Barrett 1971, fig. 7.)

designed to aid the commercial fishery, and thus reflected changes in the stock occurring prior to exploitation by the commercial fishery. Also, since the lengthfrequency data showed that the party boats exploited younger bonito than the commercial fishery, they further assumed that the party-boat CPUE provided an index of prerecruit abundance of fish before they are exploited by the commercial fishery approximately $3 \mathrm{yr}$ later. They computed a "combined" party-boat CPUE index which took into consideration mortality and recruitment and related it to the aerial survey day index for the period 1963-72 (Fig. 28). They concluded that the party-boat CPUE appears to be a valid indicator of recruitment to the commercially exploitable segment of the bonito stock, at least during this period. The party-boat CPUE from 1936 to 1973 indicated recruitment was very low before 1957, after which it increased sharply (Fig. 29) (MacCall et al. 1976). MacCall et al. further stated that $S . c$. lineolata, for unknown reasons unrelated to fishing, became scarce during the early 1940's and that subsequently and until 1956 , the party boats were dependent on migratory fish. They noted that after 1956 ". . large quantities of bonito moved into California

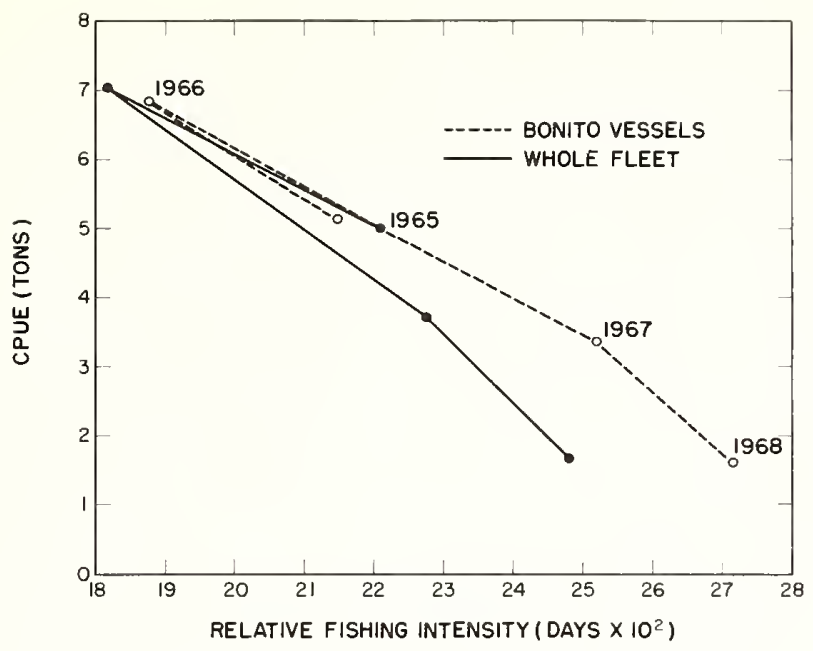

Figure 27.-Apparent abundance of Sarda chiliensis chiliensis in relation to relative fishing intensity from data for the bonito vessels only (dashed line) and for the fleet monitored by IFOP (Instituto de Fomento Pesquero) (solid line), 1965-68. (From Barrett 1971, fig. 9.)

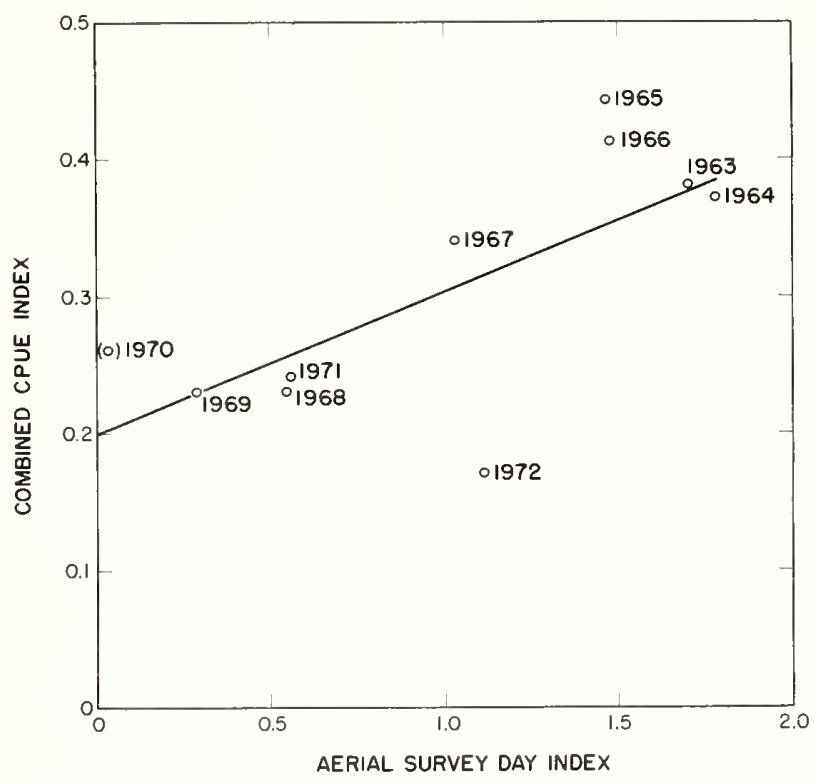

Figure 28.-Regression of aerial survey day index against CPUE adjusted for mortality and recruitment for Sarda chiliensis lineolata. (Note: Although the authors did not state how the line was fit, presumably, the least squares method was used.) (From MacCall et al. 1976, fig. 12.)

waters and became re-established as a locally spawning population." During the 1960 's young S. c. lineolata were abundant inshore and sports fishermen landed record numbers; however, since 1969 the sport catch has fallen drastically (Collins and MacCall 1977).

\section{Sarda orientalis}

The mean monthly landings and catch rates for $S$. orientalis in waters off southern Japan (Fig. 30) showed that 


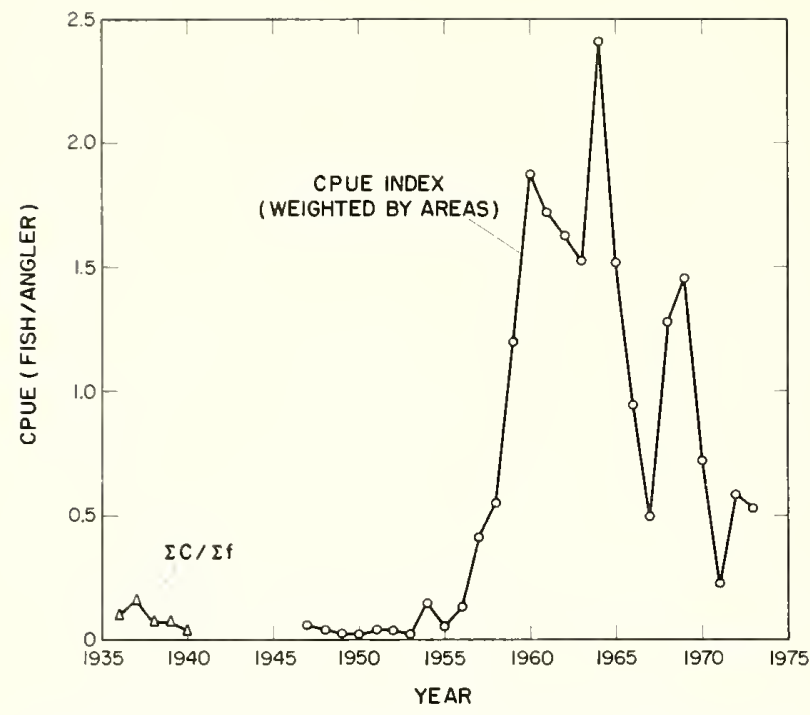

Figure 29.-Party-boat Sarda chiliensis lineolata CPUE as an index of annual recruitment. (From MacCall et al. 1976, fig. 13.)
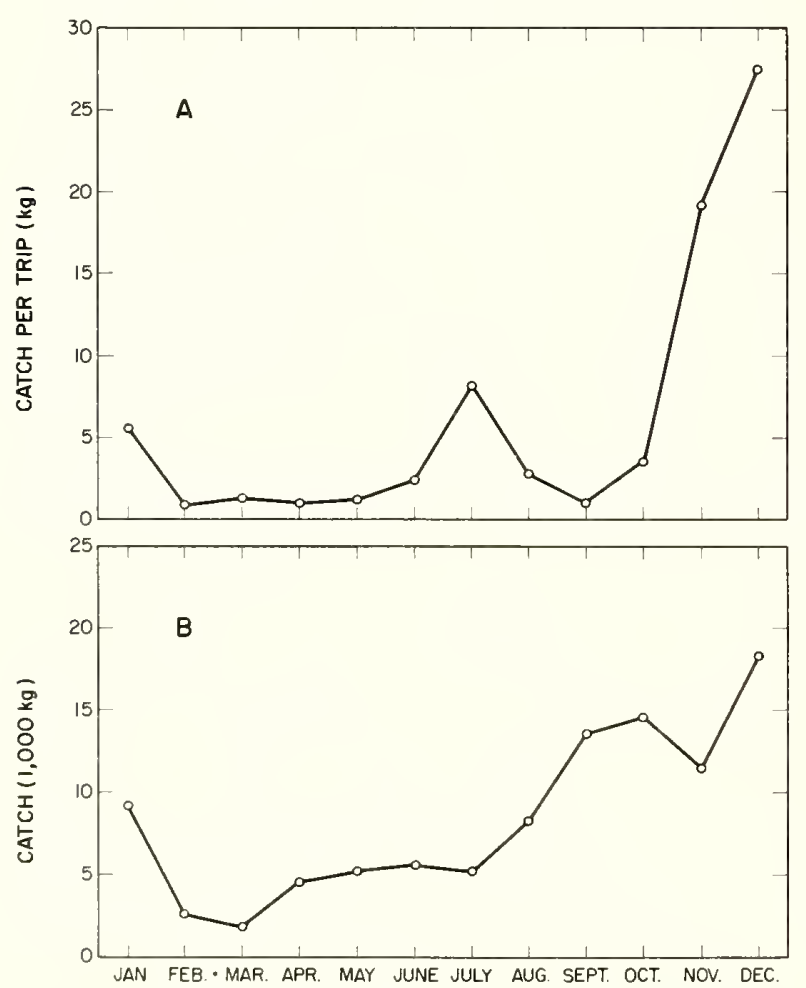

Figure 30.- Seasonal landings and catch rates of Sarda orientalis in southern Japan. A-Mean monthly catch per trip by trolling in the Aburatsu, southern Kyushu, Japan, fishery for Sarda orientalis, 1970-73. B-Mean monthly landings of Sarda orientalis at Tosashimizu and Muroto, Kochi, Japan, by various fishing methods 1967-73. (Data provided by S. Kikawa, Far Seas Fisheries research laboratory, and T. Koto, Nansei Regional Fisheries Research Laboratory, Japan.)

both the landings and catch per trip of $S$. orientalis were relatively higher during the fall-winter months, indicating that there are seasonal differences in the avail- ability or abundance of $S$. orientalis off the coast of southern Japan.

\section{Sarda sarda}

Wide fluctuations in the landings of $S$. sarda in the Black Sea-Mediterranean Sea area are a characteristic of this fishery (Fig. 31), and investigators in this area have been trying to find the causes of the fluctuations. Artuz (1959) noted that the landings at the Istanbul fish market showed fluctuations following a 9-yr cycle during the period from 1936 to 1958 (Fig. 32). As stated earlier, part of the fluctuations were explained by the entry into the fishery of rich year classes. However, Mayorova and Tkacheva (1959) pointed out that although relatively good year classes develop in certain years, these fish fail

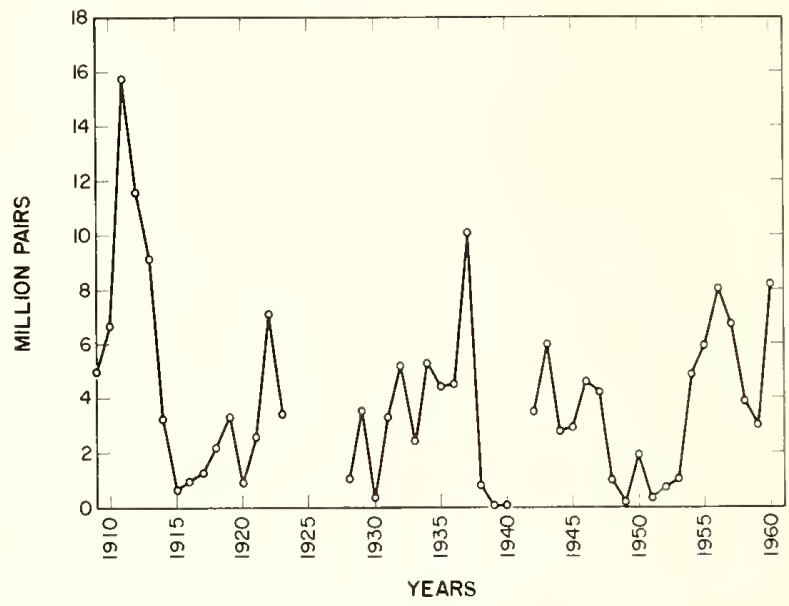

Figure 31.-The catches of Sarda sarda recorded at the Istanbul fish market, Turkey, 1909-60 (1 pair = two fish). (From Demir 1963, fig. 13.)

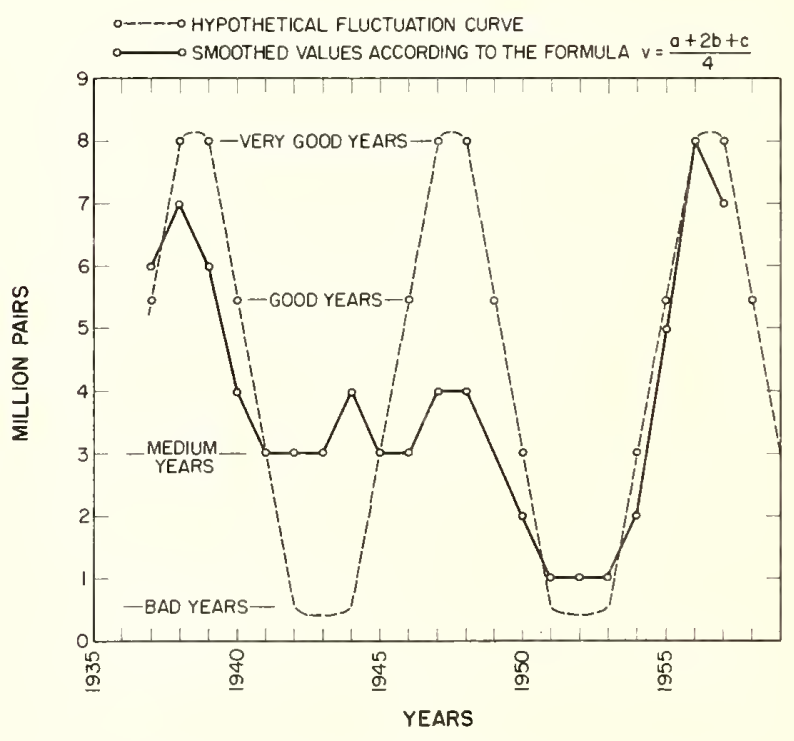

Figure 32.-Fluctuation pattern of Sarda sarda landed at the Istanbul fish market 1936-58. (From Artuz 1959, fig. 1.) 
to return to the Black Sea. They concluded that ". . . the rich yield of young fish in the Black Sea is not always followed by an increase in the abundance of large pelamid."

Artuz (1959) also indicated a possibility of an inverse relation between the relative abundance of $S$. sarda and the mackerel, Scomber scombrus, in Turkish waters from 1940 to 1956 (Fig. 33).

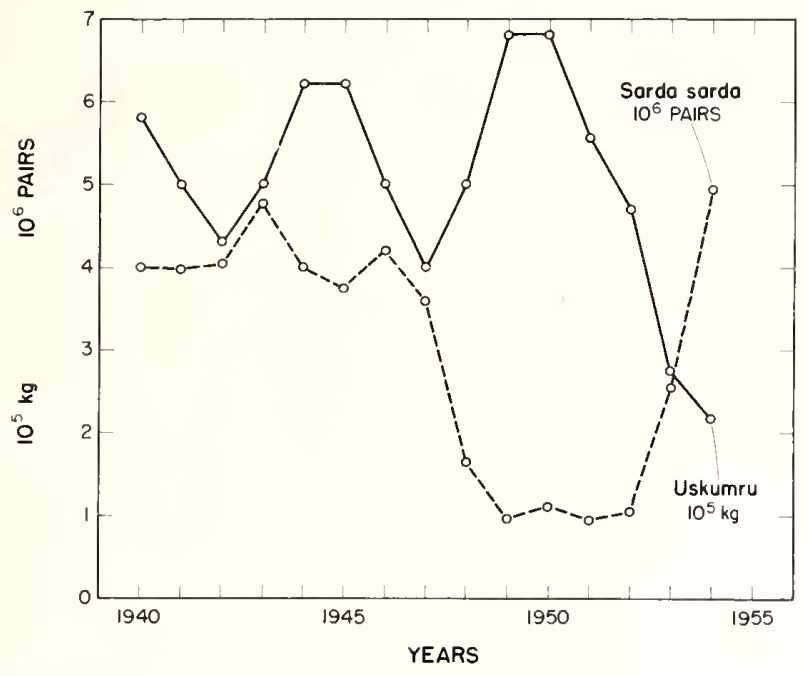

Figure 33.-Alternative occurrence of Sarda sarda (pairs) and uskumru, Scomber scombrus, (kg) landed from Turkish waters during the period 1940-56. (From Artuz 1959, fig. 5.)

\subsection{Dynamics of population}

Barrett (1971) was unsuccessful in developing a stock production model, following Schaefer (1954), for the Chilean bonito fishery. He cited as the cause of this the fact that the necessary assumptions for this type of model were unsatisfied. One of the requisite assumptions of the model is a stable age and size distribution in the population. The rapidly occurring changes in the fishery since 1965 have likely made this assumption untenable, according to Barrett. Another factor that affected the development of the model was the apparent discontinuous seasonal availability of some size classes of bonito in the fishery. Barrett concluded that he could not determine whether the fishery was stabilized or in a state of overfishing, and therefore recommended an accelerated research program on the Chilean bonico.

MacCall et al. (1976) developed a surplus production model for the Northern Hemisphere bonito in California waters (Fig. 34). They used total catch data and a combination of CPUE for the party-boat fishery and aerial survey index for the period 1963 through 1972 to develop the model. The model indicated that the Northern Hemisphere bonito is being harvested at or above the maximum sustainable yield. MacCall et al. cautioned, however, that the assessment was confounded by the possibility of a density independent decline in recruit- ment. They noted that the California catch of S. c. lineolata in 1973 appeared to be greatly in excess of the equilibrium yield. They stated, however, that conclusions drawn from the production model must be viewed with caution because bonito fishing in California waters is influenced by ocean temperatures.

Because of the lack of necessary data, MacCall et al. did not attempt a yield per recruit analysis.

Collins and MacCall (1977) determined a spawnerrecruit relationship for $S$. c. lineolata during the period from 1964 to 1974 and found no simple functional curve to describe the relationship. They found that in some years a large spawning biomass was related to larger recruitment than did a small spawning biomass; however, in some years poor recruitment was also related to a high spawning biomass as well as to a low spawning biomass.

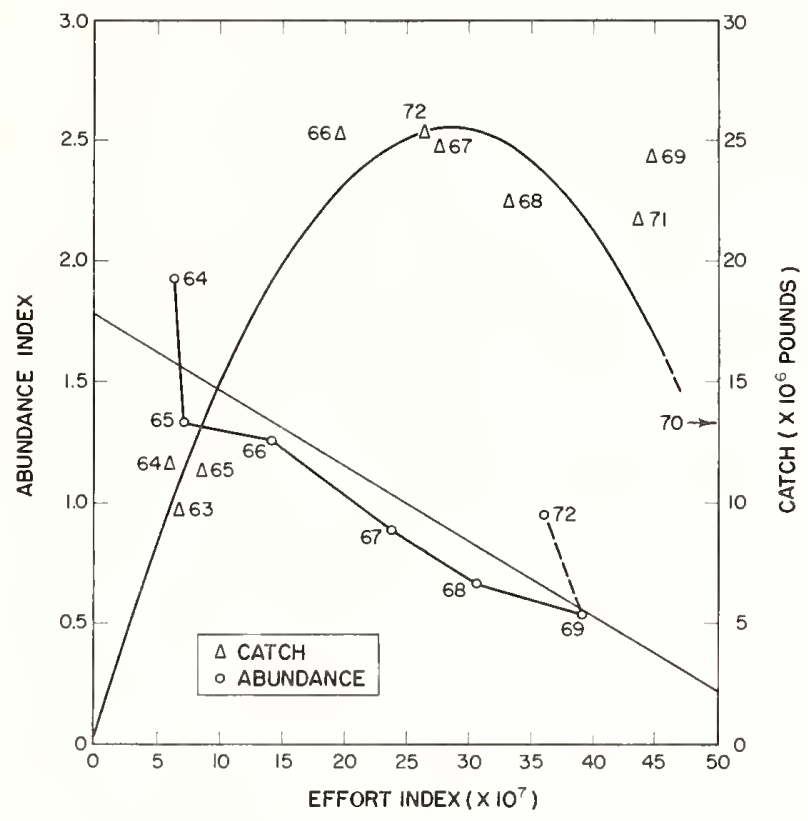

Figure 34.-Sarda chiliensis lineolata equilibrium yield and abundance in California waters. (From MacCall et al. 1976, fig. 14.)

4.6 The population in the community and the ecosystem

MacCall et al. (1976) analyzed trophic interaction between forage (northern anchovies, Engraulis mordax, and Pacific sardines, Sardinops sagax) and game fish (yellowtail, Seriola dorsalis; bonito, Sarda c. lineolata; albacore, Thunnus alalunga; barracuda, Sphyraena argentea; and white seabass, Cynoscion nobilis) in California waters. It appeared that there was little evidence that either forage or game fish biomass showed strong dependence on the abundance of the other. It appeared more likely that the abundance of both was determined largely by external conditions. 


\section{EXPLOITATION}

\subsection{Fishing equipment}

\section{Sarda australis}

Sarda australis are generally taken incidentally by trollers who use the fillets as snapper bait or by sports fishers who use it as bait for billfishes and sharks (Grant 1972).

\section{Sarda chiliensis}

The California fishery uses various kinds of gear to catch $S$. c. lineolata including trolling gear and purse seine. The largest landings are made by the local purse seiners and the trolling fleet lands a lesser amount. The high-sea purse seiners may occasionally catch bonito to fill out the loads of other tunas (Frey 1971).

In a study of the California sport fishery it was found that $S$. c. lineolata made up the biggest part of the fish catch by a single species (Pinkas et al. 1968). Bonito are taken in party and private boats, from piers and jetties, and from the shoreline. They will strike at most bait and lures, and fishing techniques for bonito vary from still fishing to trolling.

The Chilean bonito fishery prior to 1964 was conducted almost entirely on an "artisanal, semi-industrial dayfishery basis" primarily from the ports of Iquique and Antofagasta (Barrett 1971). The vessels used in this fishery are known as "faluchos" and are about $10 \mathrm{~m}$ long. They fish principally with floating gill nets or with small purse seines called "boliches," which are hauled manually. During the period from 1964 to 1966, two modern $36 \mathrm{~m}$ tuna/bonito seiners and eight other bonito/tuna seiners entered the fishery. All the new purse seiners in the bonito fishery have power launches and power blocks and use nylon nets ca. 549-732 m (300-400 fathoms) long and ca. $73-110 \mathrm{~m}$ (40-60 fathoms) deep.

The fishing gear and vessels of the Peruvian fishery have been described by Ancieta (1963).

\section{Sarda orientalis}

In Japan this species is taken by various gear including trolling gear, pole and line, purse seines, and set nets. There is no exclusive fishery for $S$. orientalis in Japan; it is taken together with species that inhabit or enter the coastal waters of Japan in multispecies fisheries employing various gear. In the Philippines $S$. orientalis are taken mostly in traps (Warfel 1950). In the Indian Ocean fishery $S$. orientalis are taken primarily by drift nets (gill nets) in India and Sri Lanka.

\section{Sarda sarda}

Sarda sarda are taken by trap net, ring net, gill net, trammel net, purse seine, beach seine, and hook and line (Demir 1963).

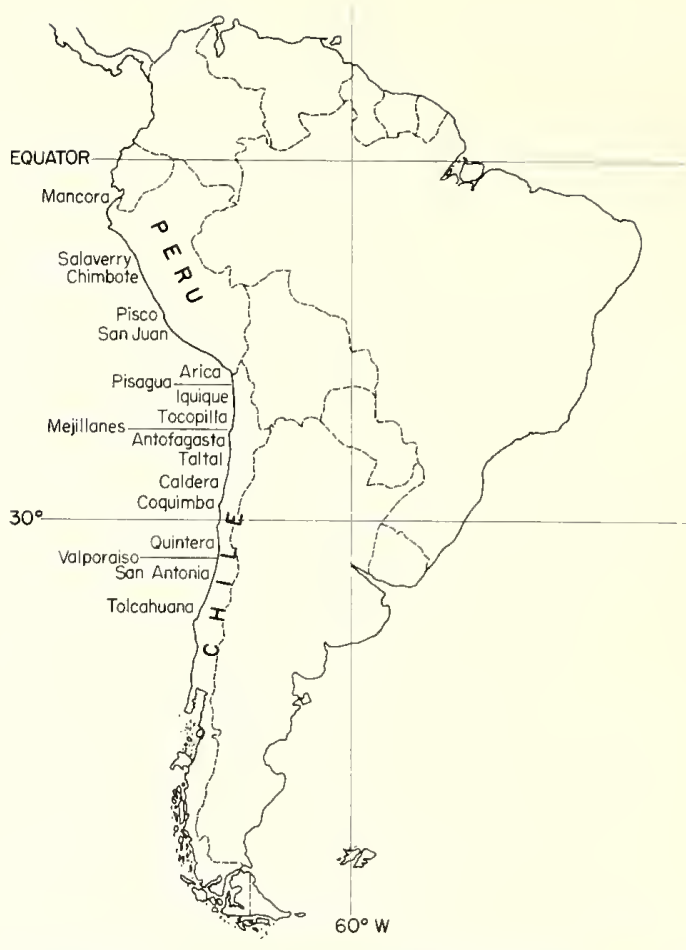

Figure 35.-Fishing ports of the Peruvian and Chilean fisheries for Sarda chiliensis chiliensis. (Adapted from Barrett 1971, fig. 1.)

\subsection{Fishing areas}

\section{Sarda australis}

There apparently is no well-developed fishery for $S$. australis in Australia. It occurs on the eastern coast of Australia along Queensland, New South Wales, and as far south as Port Fairy in Victoria. Serventy (1941a) stated that "... the bonito appears to be numerous enough to be regarded as a commercially important tuna, and a fishery could be maintained throughout the year on the eastern coast." Marshall (1964) noted that $S$. australis is destined to be of economic importance in Australia some day. There seems to be a difference of opinion on the food quality of S. australis. Grant (1972) stated that the flesh of the Australian bonito is dark red and its edible qualities are not highly regarded, whereas Marshall (1964) claimed that the flesh is light-colored, of delicate flavor, and of good canning quality.

\section{Sarda chiliensis}

The Northern Hemisphere S. chiliensis is most abundant in the area from Point Conception, Calif., to Magdalena Bay, Baja California (Frey 1971), and presumably this is the area in which the California-Mexico fishery for this species is conducted. Although the market for this species is limited, this bonito has been commercially fished in California waters since around 1900. However, the percentage of the California catch 
made north of the California-Mexico border has been declining. From 1965 to 1968, over $90 \%$ of the California catch was made north of the border; during 1969-74, it was reduced to $70 \%$. There are two semi-independent $S$. c. lineolata fisheries in the northeastern Pacific: a southern California fishery conducted by small purse seiners and a fishery conducted by the high-seas tuna fleet in southern Baja California (MacCall see footnote 5).

The Southern Hemisphere population of $S$. chiliensis is exploited by the fisheries of Peru and Chile. The Peruvian fishery extends along the coastline from the port of Mancora (ca. lat. $04^{\circ} \mathrm{S}$, long. $81^{\circ} \mathrm{W}$ ) to the port of Ilo (ca. lat. $17^{\circ} 30^{\prime} \mathrm{S}$, long. $71^{\circ} 15^{\prime} \mathrm{W}$ ) (Ancieta 1963), and the Chilean fishery extends from Arica (ca. lat. $20^{\circ} 15^{\prime} \mathrm{S}$, long. $70^{\circ} 15^{\prime} \mathrm{W}$ ) to Talcahuano (ca. lat. $37^{\circ} 45^{\prime} \mathrm{S}$, long. $73^{\circ} \mathrm{W}$ ) (Barrett 1971) (Fig. 35).

\section{Sarda orientalis}

Fisheries for this species are not very well developed throughout its distributional range. The FAO Yearbook of Fishery Statistics (e.g., FAO 1974) does not show any $S$. orientalis landings. The $S$. orientalis found in the tropical eastern Pacific between central Baja California and Peru is of little commercial importance and when caught may enter the catch statistics grouped with $S$. chiliensis (Pinkas 1961). This species is uncommon around Hawaii, and when landed the catches are not identified in the statistics published by the State.

In Japan $S$. orientalis occurs in waters south of central Honshu along both the Pacific and Japan Sea coasts. It is

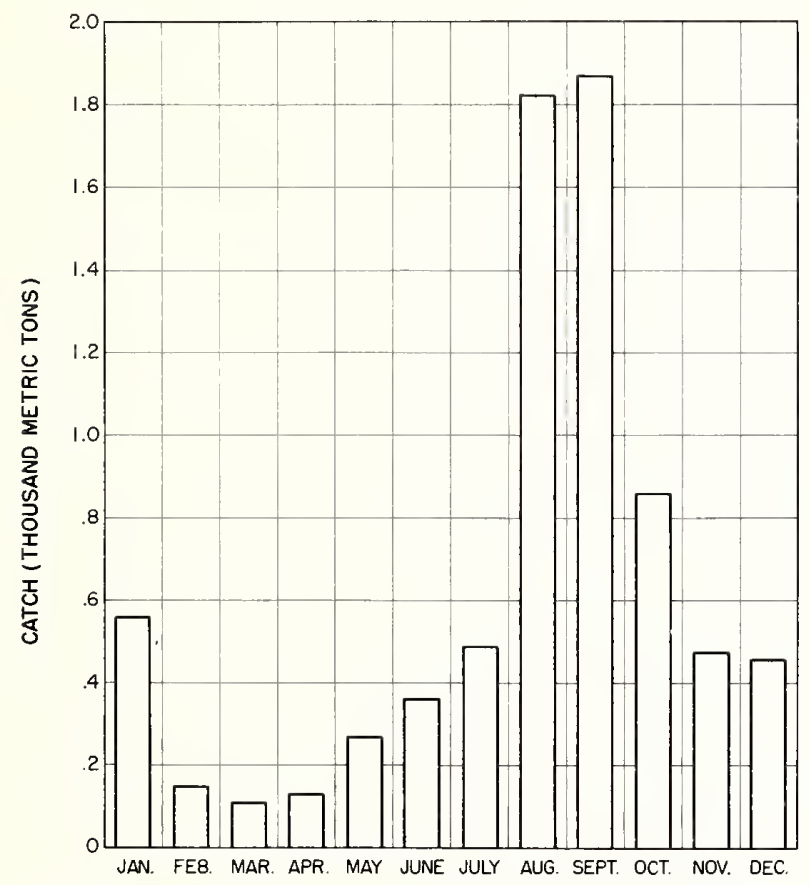

Figure 36.-Mean monthly landings and shipments into California of Sarda chiliensis lineolata, 1968-72. (Data from Heimann and Carlisle 1970; Pinkas 1970, 1974; Bell 1971; Oliphant and Marine Fisheries Statistics Staff. Marine Resources Region 1973.) most abundant in the coastal waters of Kyushu (Kikawa and Staff of the Nankai Fisheries Research Laboratory, Kochi, Japan 1963).

In the Indian Ocean minor fisheries for $S$. orientalis have been reported off the southwest tip of India (Silas 1964), in the Gulf of Aden along the coast of Somalia (Laevastu and Rosa 1963), and around Sri Lanka (Sivasubramaniam 1969).

\subsection{Fishing seasons}

\section{Sarda australis}

No information.

\section{Sarda chiliensis}

The mean monthly landings of $S$. c. lineolata in California for the 5-yr period from 1968 to 1972 indicate that the fishery is seasonal (Fig. 36). Although bonito was landed throughout the year in this 5-yr period, peak landings occurred in August-October.

Bonito is landed throughout the year in Chile and Peru, but both fisheries have seasonal peaks (Fig. 37). The seasonal peak is in October-November in Chile, whereas it occurs in January in the Peruvian fishery.
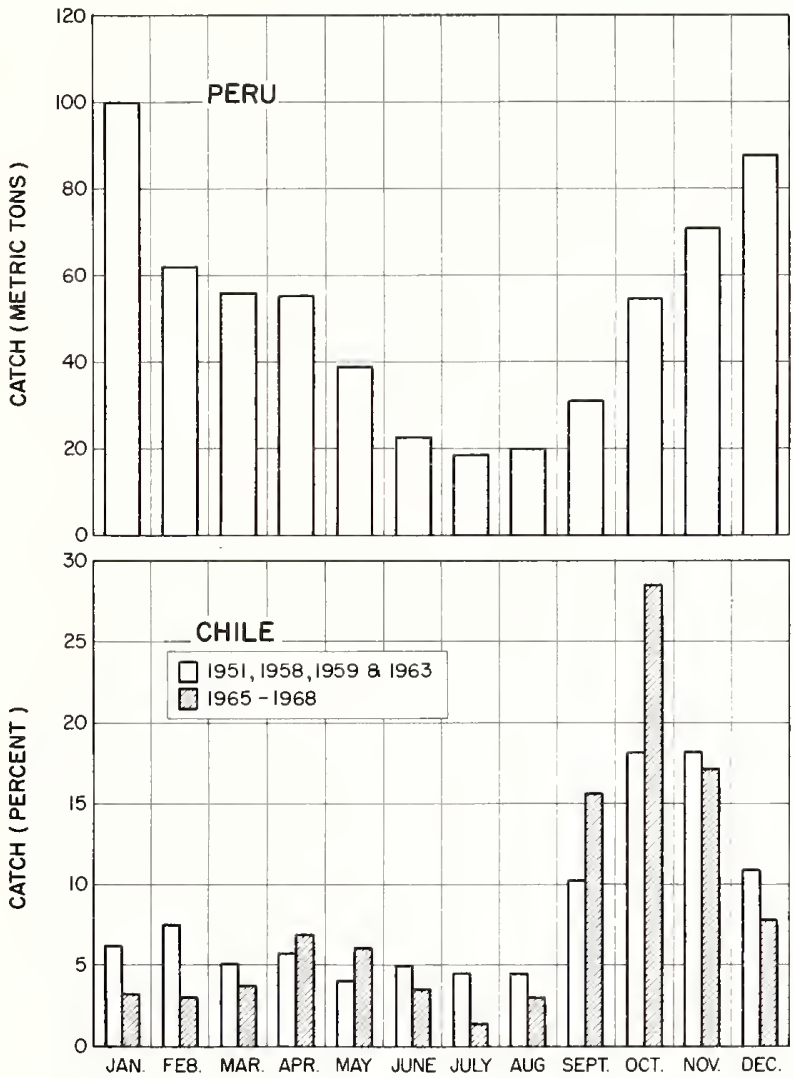

Figure 37.-Mean monthly landings of Sarda chiliensis chiliensis in Peru, 1951-59 (data from Ancieta 1963, table 1) and Chile (from Barrett 1971, fig. 2.) 


\section{Sarda orientalis}

In the Indian fishery stray specimens may be taken in April, May, and June; however, the main fishing season appears to be from about July to September (Silas 1963). In nearby Sri Lanka, S. orientalis appears in the catches throughout the year off the south coast. Mature fish are taken along the northeast coast from June-August and off the south and southwest coasts between September and February. The juveniles appear off the west coast usually during the southwest monsoon in June-August (Sivasubramaniam 1969).

\section{Sarda $\operatorname{sarda}$}

The fishing seasons for $S$. sarda in various areas are summarized in Table 8. Rodríguez-Roda (1966) summarized the fishing seasons in the Spanish fishery by various geographical areas in the eastern Atlantic and the western Mediterranean (Table 9). Apparently the fishing seasons in the Black Sea-Aegean Sea areas are related to the migrations of $S$. sarda. There is disagreement on the exact routes of the migration in certain areas, and the routes are unclear in other areas, but it is certain that $S$. sarda does migrate back and forth from the Aegean Sea, Sea of Marmara, and the Black Sea. According to Demir (1957), schools of $S$. sarda spend the summer in the Black Sea and the winter in the Sea of Marmara and the Aegean Sea. Thus, the fishing season of May-October coincides with the time the migrating $S$. sarda are in the Black Sea in the summer. The fishing peaks of April-May and September-December in the Sea of Marmara coincide with the spring migration of the bonitos from the Aegean Sea through the Sea of Marmara to the Black Sea and the fall return migration from the Black Sea to the Aegean Sea.

No information is available on the migration of $S$. sarda in the other areas of the Mediterranean and in the Atlantic Ocean. The seasonal development of the Spanish fishery in various areas of the western Mediterranean, however, suggests that S. sarda may be migrating to and from the western Mediterranean (see Table 9).

\subsection{Fishing operations and results}

The four species of Sarda are the bases of many fisheries throughout the world. Detailed information on the fisheries, however, is available only from a relatively few fisheries. Sarda australis, being found only along the coast of eastern Australia and around Norfolk Island east of Australia, is the object of a small incidental fishery in Australia. According to statistics published by FAO in the Yearbook of Fishery Statistics, S. c. lineolata is the basis of fisheries by Mexico and the United States. Sarda c. chiliensis is exploited by Chile and Peru. Landings of S. orientalis do not appear in the FAO Yearbook of Fishery Statistics (see FAO 1974). Relatively small amounts of the species are taken throughout its distributional range and it is not the basis of any well-de-

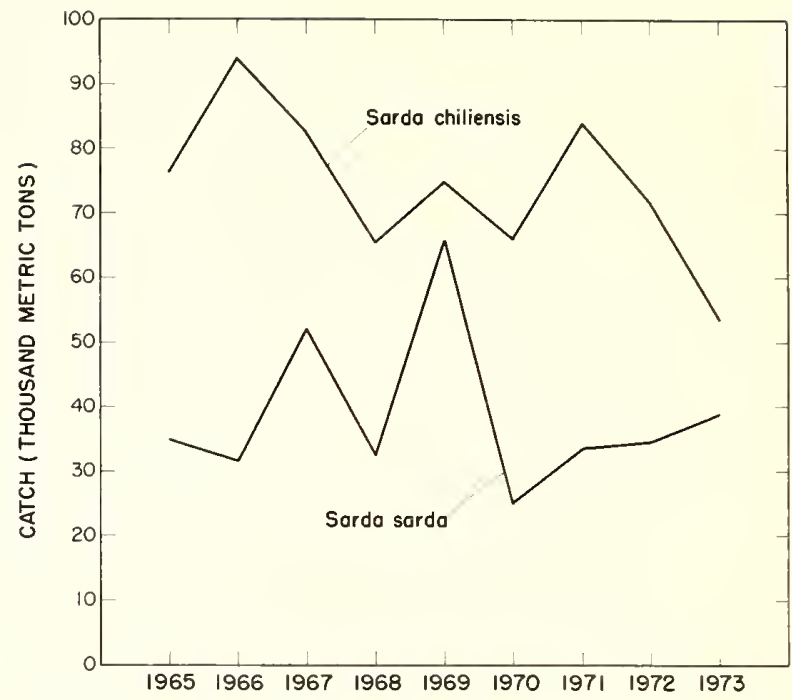

Figure 38.-Annual world landings of Sarda chiliensis and Sarda sarda, 1965-73. (Data from FAO 1974.)

veloped fishery. Sarda sarda, on the other hand, appears to be exploited throughout its distributional range in fisheries of various sizes. In the Atlantic Ocean, the FAO Yearbook lists 18 countries reporting landings of $S$. sarda, mostly from the eastern Atlantic. Thirteen countries report landings of $S$. sarda from the Mediterranean and Black Seas. The total landings of $S$. chiliensis ranged from 53,300 to $94,100 \mathrm{t}$ during the period 1965-73 and were greater than the total landings of $S$. sarda in each of $9 \mathrm{yr}$. The landings of $S$. sarda ranged from 25,000 to $65,700 \mathrm{t}$ during the same period (Fig. 38) (FAO 1974).

\section{Sarda australis}

As can be expected from an incidental type fishery, the annual landings of $S$. australis were erratic and in some years no fish were landed at all during 1955-73 (Fig. 39). Information is meager on the utilization of the $S$. australis that are landed. They apparently are not uncommon in the wholesale fish market of Sydney, Australia (Collette ${ }^{6}$ ).

\section{Sarda chiliensis}

The landing figures of S. c. lineolata in California and Mexico show that Mexican landings make up only a small proportion of the total in the Northern Hemisphere (Fig. 40). From 1965 to 1973, the California landings constituted from about 77 to $100 \%$ of the total landings of bonito north of the equator in the eastern $\mathrm{Pa}$ cific. The annual landings have been erratic, and to some

\footnotetext{
${ }^{6}$ Collette, B. B., Systematics Laboratory, National Marine Fisheries Service, NOAA, National Museum of Natural History, Washington, D.C. 20560, pers. commun. February 1978.
} 


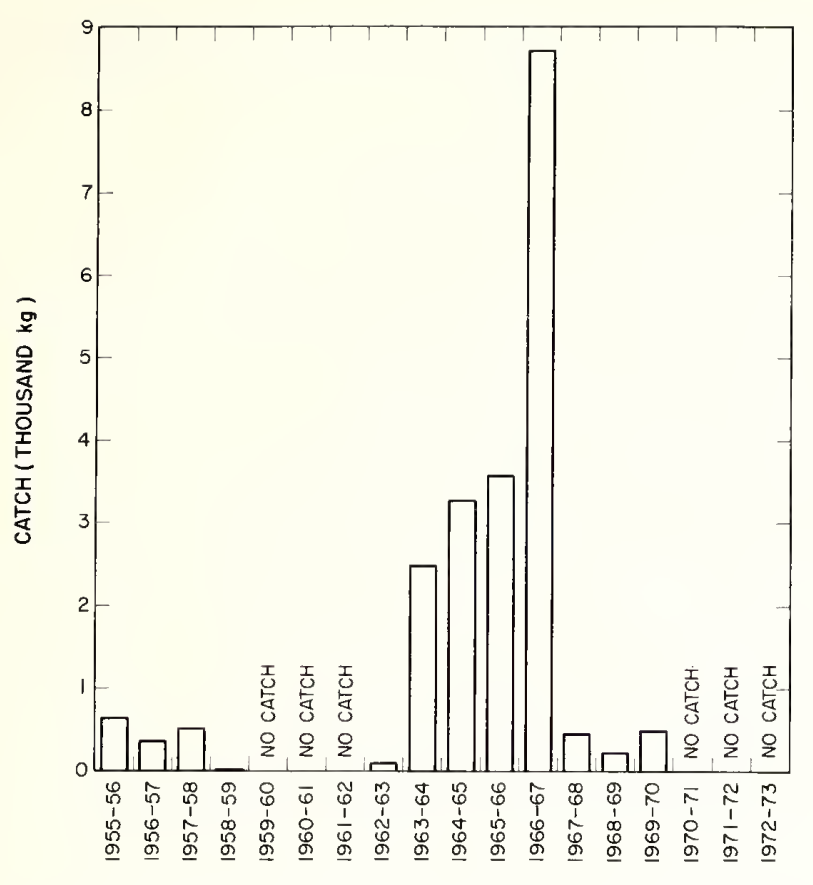

Figure 39.-Annual landings of Sarda australis in Australia. (Data from Australia. Fisheries Branch, Department of Primary Industry 1957-74.)

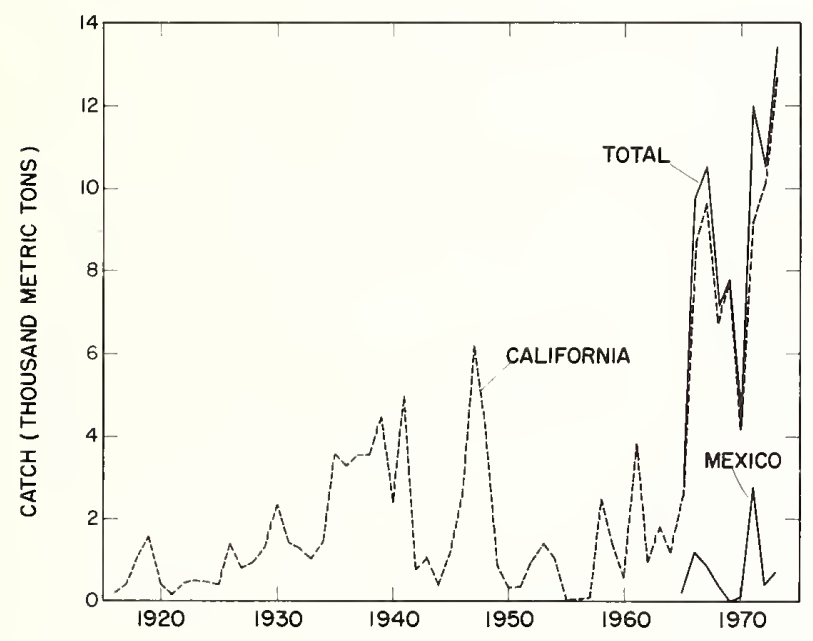

Figure 40.-California and Mexico landings of Sarda chiliensis lineolata. (Data from Bell 1971; Frey 1971; Oliphant and Marine Fisheries Statistics Staff. Marine Resources Division 1973; FAO 1974; Pinkas 1974.)

extent reflect the relative availability of the species in southern California and Mexican waters. It was believed that up until the early 1970's the landings did not reveal the condition of the stock because the bonito is caught incidentally or in lieu of more desirable species in the California fishery (Frey 1971). However, it is now believed that the recent small landings in California strongly indicate a low level of bonito abundance (MacCall see footnote 5).

The California party-boat landings of $S$. c. lineolata (Fig. 41) probably also better reflected the availability of

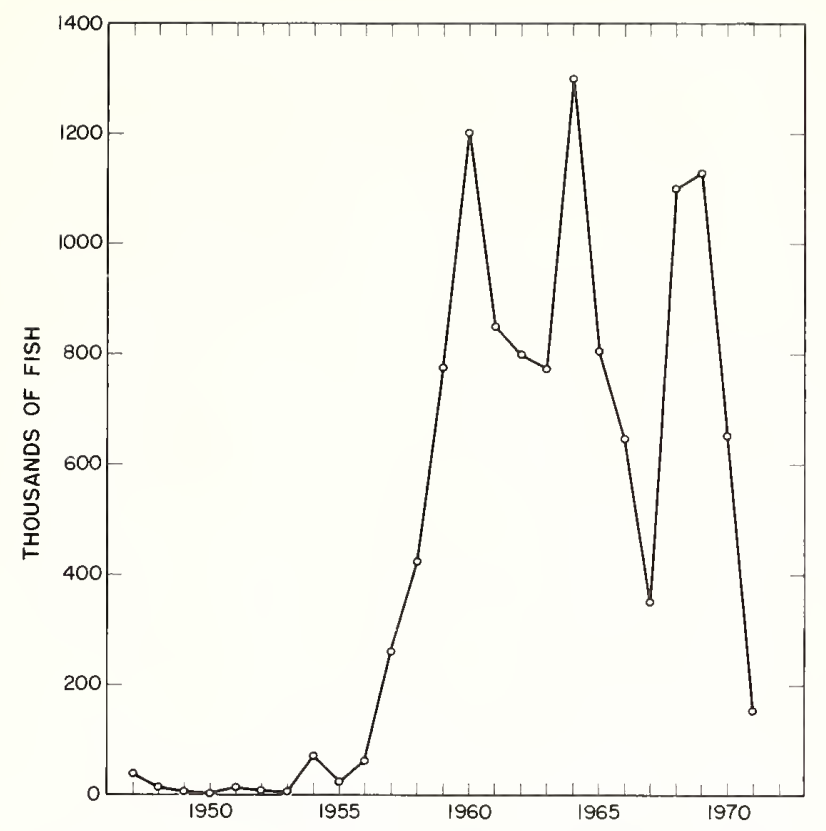

Figure 41.-Landings of Sarda chiliensis lineolata by the California party-boat fleet. (Data from Frey 1971; Oliphant and Marine Fisheries Statistics Staff. Marine Resources Region 1973.)

bonito rather than the condition of the stock up until the early 1970's. The party-boat fishery is a multispecies fishery and many other species of fish in addition to the bonito are taken. Furthermore, the bonito is under a form of management in that sports fishermen may not possess more than 10 bonito/day. There is some indication that water temperature may affect the relative availability of bonito to the party-boat fishery in California waters. Party-boat landings of bonito were lower in the 6-yr period 1948-53, which were cold-water years in California (Young 1969). More recent data indicate that party-boat landings reflect the recruitment strength to the northern segment of the stock and therefore indicate the condition of the stock itself a couple of years later; also, catch per angler is a better measure of young fish abundance than is total landings (MacCall see footnote 5).

The landings of $S$. c. chiliensis in the fisheries of Peru and Chile (Fig. 42) indicate that the bulk of the landings is made in the Peruvian fishery. Chile's share of the Southern Hemisphere landings of bonito varied from about 2 to $15 \%$ of the total annual landings from 1965 to 1973. The annual Peruvian landings except for minor fluctuations increased steadily from 1941 and reached a peak of $104,000 \mathrm{t}$ in 1961. The landings, with minor fluctuations, have been declining since then. Except for 1955 , when the landings of bonito amounted to $7,500 \mathrm{t}$, the annual landings in Chile were $<5,000 \mathrm{t}$ during the period from 1940 to 1963 . The landings increased sharply in 1965 and reached a peak in 1966 as the result of the entry of several new, modern purse seiners into the fishery in 1964-66 (Barrett 1971). They have, however, declined in subsequent years. 


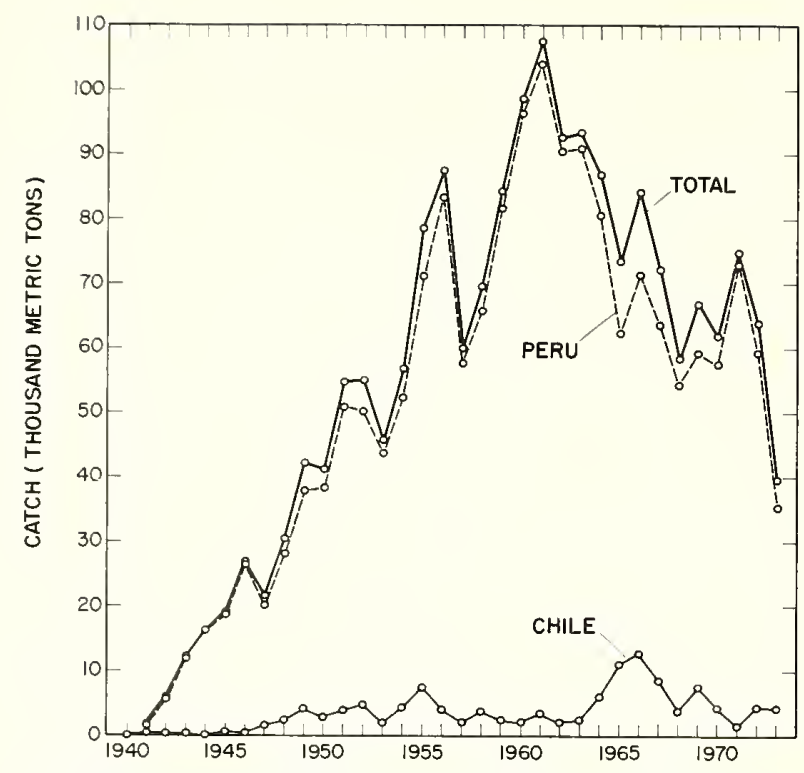

Figure 42.-Landings of Sarda chiliensis chiliensis in Peru and Chile. (Data from Ancieta 1963; FAO 1965, 1974; Barrett 1971.)

\section{Sarda orientalis}

The landings of this species are not identified in the statistics published by the Japanese Government. Apparently, landing records are maintained by prefectural "fishery guidance stations," but these statistics are presumably not published or not readily available.

Table 24 gives the annual landings made at four ports in southern Japan, Tosashimizu, Muroto, Murotomisaki, and Aburatsu, from 1967 to 1974.

There apparently is a minor fishery for $S$. orientalis in the Philippines. Warfel (1950) made a survey of the outlook for the development of a tuna industry in the Philippines. He presented some statistics showing the landings (number of fish) of $S$. orientalis at three Philippine markets: 369 at Batangas, 2,308 at Iloilo, and 6,762 at Zamboanga.

Sivasubramaniam (1969) concluded that the apparent abundance of $S$. orientalis around Sri Lanka was so low that it was not worth an attempt to develop a fishery for this species. He noted that not more than a few hundred

Table 24.-Annual landings (in kilograms) of Sarda orientalis in fou southern Japan ports. (Data provided by S. Kikawa, Far Seas Fish. eries Research Laboratory, and T. Kato, Nansei Regional Fisheries Research Laboratory, Japan.) (ND = No data.)

\begin{tabular}{lccccc}
\hline & \multicolumn{5}{c}{ Landings in kilograms } \\
\cline { 2 - 6 } Year & Tosashimizu & Muroto & Murotomisaki & Aburatsu & Total \\
\hline 1967 & 37,462 & ND & ND & ND & 37,462 \\
1968 & 22,171 & ND & ND & ND & 22,171 \\
1969 & 30,024 & ND & ND & ND & 30,024 \\
1970 & 30,718 & ND & ND & 25,461 & 56,179 \\
1971 & 256,939 & 42,595 & ND & 31,732 & 331,266 \\
1972 & 229,722 & 41,220 & ND & 9,994 & 280,936 \\
1973 & 299,621 & 13,152 & 11,294 & 8,426 & 332,493 \\
1974 & ND & ND & 11,710 & ND & 11,710 \\
\hline \multicolumn{7}{c}{}
\end{tabular}

pounds were taken in 1964 and estimated that the annual catch was about a ton in 1969 .

\section{Sarda sarda}

There are commercial fisheries of varying sizes almost throughout the entire distributional range of $S$. sarda in the eastern and western Atlantic and in the Mediterranean and Black Seas (Table 25).

Table 25.-Countries with fisheries for Sarda sarda. (Compiled from FAO 1974.)

\begin{tabular}{ll} 
Countries exploiting Sarda sarda in & the eastern Atlantic: \\
Angola & Morocco \\
Bulgaria & Portugal \\
Equat orial Guinea & Romania \\
German Democratic Republic & Spain \\
Greece & U.S.S.R. \\
\multicolumn{3}{c}{} \\
Countries exploiting Sarda sarda in the western Atlantic: \\
Argentina & Mexico \\
Brazil & United States \\
Grenada & Venezuela \\
Martinique & \\
& \\
Countries exploiting Sarda sarda in & the Mediterranean and Black Seas: \\
Algeria & Romania \\
Bulgaria & Spain \\
Cyprus & Tunisia \\
Greece & Turkey \\
Italy & U.S.S.R. \\
Malta & Yugoslavia \\
Morocco & \\
\hline & \\
\hline
\end{tabular}

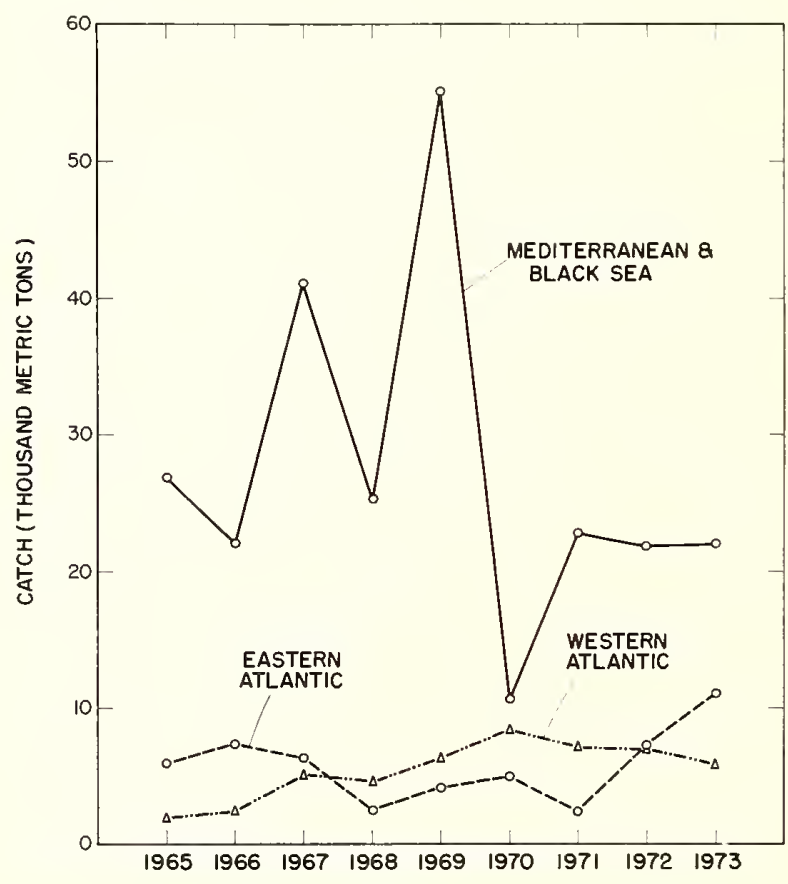

Figure 43.-Annual landings of Sarda sarda in the Atlantic and Mediterranean-Black Seas. (Data from FAO 1974.) 
Table 26.-Annual landings of Sarda sarda (thousands of metric tons). (Data from FAO 1974.)

\begin{tabular}{|c|c|c|c|c|c|c|c|c|c|}
\hline & 1965 & 1966 & 1967 & 1968 & 1969 & 1970 & 1971 & 1972 & 1973 \\
\hline \multicolumn{10}{|c|}{ Eastern Atlantic: } \\
\hline North & 2.7 & 2.7 & 1.6 & 0.8 & 2.1 & 1.9 & 0.8 & 6.1 & 1.5 \\
\hline Central & 1.9 & 3.0 & 3.0 & 1.3 & 1.2 & 1.9 & 0.9 & 0.5 & 9.0 \\
\hline South & 1.3 & 1.6 & 1.7 & 0.4 & 0.9 & 1.2 & 0.7 & 0.6 & 0.5 \\
\hline Total & 5.9 & 7.3 & 6.3 & 2.5 & 4.2 & 5.0 & 2.4 & 7.2 & 11.0 \\
\hline \multicolumn{10}{|c|}{ Western Atlantic: } \\
\hline North & 0.1 & 0.0 & 0.0 & 0.0 & 0.1 & 0.1 & 0.0 & 0.0 & 0.0 \\
\hline Central & 0.3 & 0.4 & 0.5 & 0.8 & 0.8 & 0.7 & 1.0 & 1.2 & 1.8 \\
\hline South & 1.5 & 2.0 & 4.6 & 3.8 & 5.4 & 7.6 & 6.1 & 5.7 & 4.0 \\
\hline Total & 1.9 & 2.4 & 5.1 & 4.6 & 6.3 & 8.4 & 7.1 & 6.9 & 5.8 \\
\hline \multicolumn{10}{|c|}{ Mediterranean and Black Seas: } \\
\hline & 26.9 & 22.1 & 41.1 & 25.3 & 55.2 & 10.6 & 22.9 & 21.9 & 22.0 \\
\hline
\end{tabular}

The annual landings of $S$. sarda in the eastern and western Atlantic and in the Mediterranean-Black Seas during the period from 1965 to 1973 show that except in 1973 when the eastern Atlantic landings exceeded 10,000 $t$, the landings in the eastern and western Atlantic never rose above this figure (Fig. 43, Table 26). The fisheries of Spain and Portugal make up the landings in the eastern Atlantic. In the western Atlantic the bulk of the landings is made by the fisheries of Argentina and Brazil. The landings in the Mediterranean and Black Seas fluctuated from 10,600 to $55,200 \mathrm{t}$ during the period from 1965 to 1973 . Turkey contributed 71.7 to $91.3 \%$ of the annual landings during this period.

\section{PROTECTION AND MANAGEMENT}

\subsection{Regulatory measures}

There are no measures regulating the commercial fisheries for any of the species of Sarda. The State of California imposes a bag limit of $10 \mathrm{~S}$. c. lineolata per day for recreational fishermen (Frey 1971), and is presently seeking to impose regulations on the California commercial fishery (MacCall see footnote 5).

\section{LITERA'TURE CI'TED}

ANCIETA, F.

1963. La pesquería del bonito en el Perú. FAO Fish. Rep. 6, 3:1607-1619.

1964. Sinopsis sobre la bíología y pesquería del "bonito" Sarda chilensis (Cuvier y Valenciennes) frente a la costa del Perú. Rev. Fac. Cienc. Biol., Univ. Nac. Trujillo 1(1):17-49.

ARTUZ, I

1959. Fluctuations in the catches of some pelagic fishes in the Marmara and Black Seas. Poc. Tech. Pap. Gen. Fish. Counc. Medit., FAO 5:303-309.

AUSTRALIA. FISHERIES BRANCH, DEPARTMENT OF PRIMARY INDUSTRY.

1957. Fish. Newsl. 16(3), 31 p.

1958. Fish. Newsl. 17(3), 35 p.

1959. Fish. Newsl. 18(3), 35 p.

1960. Fish. Newsl. 19(3), 35 p.

1961. Fish. Newsl. 20(3), 35 p.
1962. Fish. Newsl. 21(3), 43 p.

1963. Fish. Newsl. 22(4), 43 p.

1964. Fish. Newsl. 23(3), 47 p.

1965. Aust. Fish. Newsl. 24(3), 46 p.

1966. Aust. Fish. Newsl. 25(3), 46 p.

1967. Aust. Fish. Newsl. 26(3), 48 p.

1968. Aust. Fish. Newsl. 27(3), 48 p.

1969. Aust. Fish. 28(3), 52 p.

1970. Aust. Fish. 29(3), 56 p.

1971. Aust. Fish. 30(3), 52 p.

1972. Aust. Fish. 31(3), 56 p

1973. Aust. Fish. 32(3), 68 p.

1974. Aust. Fish. 33(5), 76 p.

BARNHART, P. S.

1927. Pelagic fish eggs off La Jolla, California. Bull. Scripps Inst. Oceanogr., Univ. Calif. Tech. Ser. 1:91-92.

BARRETT, I

1971. Preliminary observations on the biology and fishery dynamics of the bonito (Sarda chiliensis) in Chilean waters. [In Engl. and Span.] Inst. Fom. Pesq. Bol. Cient. 15, 55 p.

BARRETT, I., and A. A. WILLIAMS.

1965. Hemoglobin content of the blood of fifteen species of marine fishes. Calif. Fish Game 51:216-218.

1967. Soluble lens proteins of some scombroid fishes. Copeia 1967:468-471.

BEAUCHAMP, J. J., and J. S. OLSON.

1973. Corrections for bias in regression estimates after logarithmic transformation. Ecology 54:1403-1407.

BELL, R. R.

1971. California marine fish landings for 1970. Calif. Dep. Fish Game, Fish Bull. 154, 50 p.

BELLOC, G

1954. Les thons de la Méditterranée. Première note: germon, pélamide et melva. Proc. Tech. Pap. Gen. Fish. Counc. Medit., FAO 2:283-318.

BERG, L. S., A. S. BOGDANOV, N. I. KOZHIN, and T. S. RAFF 1949. Tromyslovye ruby SSR (Commercial fishes of the USSR). [In Russ.] Moscow, Pishchepromizdat, 787 p.

BIGELOW, H. B., and W. C. SCHROEDER

1953. Fishes of the Gulf of Maine. U.S. Fish Wildl. Serv., Fish. Bull. 53, 577 p.

BOESEMAN, M.

1947. Revision of the fishes collected by Burger and von Siebold in Japan. Zool. Meded. (Leiden) 28:1-242.

1964. Scombroid types in the Leiden Museum collection. Proc. Symp. Scombroid Fishes. Mar. Biol. Assoc. India, Symp. Ser. 1:461-468.

BOSCHUNG, H. T., JR.

1966. The occurrence of the common bonito, Sarda sarda, in the northern Gulf of Mexico. Trans. Am. Fish. Soc, 95:227-228. 
BLEN, F. DE.

1930. Estados larvarios y juveniles de la Sarda sarda

(Bloch). Inst. Esp. Oceanogr. Trabajos 3, 32 p.

1932. Formas ontogénicas de peces (Nota primera). Notas Resúm. [In Span.] Inst. Esp. Oceanogr., Ser. 2, 57:1-38.

1958. Peces del suborden Scombroidei en aguas de Chile. Rev. Biol. Mar., Valparaiso 7:3-38. (Engl. transl. in files of Natl. Mar.

Fish. Serv., NOAA, Honolulu, HI 96812.)

CAMPBELL, G., and R A. COLLINS.

1975. The age and growth of the Pecific bonito, Sarda chiliensis, in the eastern North Pacific. Calif. Fish Game 61:181-200.

COLLETTE, B. B., and L. N. CHAO.

1975. Systematics and morphology of the bonitos (Sarda) and their relatives (Scombridae, Sardini). Fish. Bull., U.S. 73:516-625.

COLLINS, R. A., and A. D. MacCALL.

1977. California Pacific bonito resource, its status and management. Calif. Dep. Fish Game, Mar. Res. Tech. Rep. 35, 39 p.

CUSHING, J. E.

1964. The blood groups of marine animals. Adv. Mar. Biol. 2:85131

DAWES, B

1946. The Trematoda, with special reference to British and other European forms. Cambridge Univ. Press, $644 \mathrm{p}$.

DE LA TOURRASSE, G.

1957. La pêche au thon sur la côte basque poursuit sa modernisation. Rev. Trav. Inst. Pêches Marit. 21:561-592.

DEMIR, M

1957. Migrations of Sarda sarda Bloch in the Black, Marmara, and Aegean seas; the probable spawning places and times. Proc. Tech. Pap. Gen. Fish. Counc. Medit., FAO 4:127-134.

1963. Synopsis of biological data on bonito Sarda sarda (Bloch) 1793. FAO Fish. Rep. 6, 2:101-129.

1964. Distribution of meristic counts of common bonito (Sarda sarda $\mathrm{Bl}$.) from Turkish waters. Proc. Tech. Pap. Gen. Fish. Counc. Medit., FAO 7:455-457.

DEMIR, M., and N. DEMIR.

1961. Contribution to the knowledge of the eggs of the common bonito (Sarda sarda Bloch). Proc. Tech. Pap. Gen. Fish. Counc. Medit., FAO 6:213-218.

DIEUZEIDE, R., M. NOVELLA, and J. ROLAND.

1955. Catalogue des poissons des côtes algériennes. III. Ostéoptérygiens. Bull. Stn. Aquicult. Pêche Castiglione, New Ser. 6, $384 \mathrm{p}$.

DUCLERC, J., J. SACCHI, C. PICCINETTI, G. PICCINETTI-

MANFRIN, A. DICENTA, and J.-M. BARROIS.

1973. Nouvelles données sur la reproduction du thon rouge (Thunnus thynnus L.) et d'autres especes de Thonidés en Méditerranée. Rev. Trav. Inst. Pèches Marit. 37:163-176.

ECKROAT, L. R., and J. E. WRIGHT.

1969. Genetic analysis of soluble lens protein polymorphism in brook trout, Salvelinus fontinalis. Copeia 1969:466-473.

EHRENBAUM, E.

1924. Scombriformes. Rep. Dan. Oceanogr. Exped. Medit. 19081910, II (Biology) A, 11, 42 p.

FOOD AND AGRICULTURE ORGANIZATION OF THE UNITED

NATIONS.

1965. Catches and landings, 1965. FAO Yearb. Fish. Stat. 20, 360

p.

1970. Catches and landings, 1969. FAO Yearb. Fish. Stat. 28, var. pag.

1974. Catches and landings, 1973. FAO Yearb. Fish. Stat. 36, 590

FREY, H. W. (editor).

1971. California's living marine resources and their utilization. State Calif., Resour. Agency, Dep. Fish Game, 148 p.

FURNESTIN, J., J. DARDIGNAC, C. MAURIN, A. VINCENT, R. COUPE, and H. BOUTIERE.

1958. Donnees nouvelles sur les poissons du Maroc atlantique. Rev. Trav. Inst. Pêches Marit. 22:379-493.

GNANAMUTTU, J. C.

1966. On the occurrence of the oriental bonito, Sarda orientalis (Temminck and Schlegel) along the Madras coast. J. Mar. Biol. Assoc. India 8:365.
GODSIL, H. C.

1954. A descriptive study of certain tuna-like fishes. Calif. Dep.

Fish Game, Fish Bull. 97, 185 p.

1955. A description of two species of bonito Sarda orientalis and $S$. chiliensis and a consideration of relationships within the genus. Calif. Dep. Fish Game, Fish Bull. 99, 43 p.

GORBUNOVA, N. N.

1963. Larvae of scombroid fishes (Pisces, Scombriformes) from the Indian Ocean. [In Russ., Engl. summ.] Tr. Inst. Okeanol. Akad. Nauk SSSR 62:68-95. (Engl. transl. available from U.S. Dep. Commer., Off. Tech Serv., Wash., D.C.)

GORBUNOVA, N. N., and D. SALABARIA.

1967. Reproduction of scombroid fishes (Pisces, Scombroidei) in western regions of the Atlantic Ocean. [In Russ., Span. summ.] In Sovetsko-Kubinskie Rybokhoz. Issled. Investigaciones Pesqueras Soveítico-Cubanas. Pishchevaya Promyshlennost', Moscow, p. 120-131. (Engl. transl. by W. L. Klawe, 1968, 24 p.; Inter-Am. Trop. Tuna Comm., La Jolla, Calif.)

GRANT, E. M.

1972. Guide to fishes. 2d ed. Queensl. Dep. Primary Ind., Brisbane, $472 \mathrm{p}$.

GRUVEL, A.

1931. Les états de Syrie, richesses marines et fluviales; exploitation actuelle - avenir. Bibliothéque de la Faune des Colonies Françaises, Société d'Editions Geographiques, Maritimes et Coloniales, Paris, 453 p.

HAMMOND, D. L., and D. M. CUPKA

1975. A sportsman's field guide to the billfishes, mackerels, little tunas and tunas of South Carolina. S.C. Wildl. Mar. Resour. Dep., Educ. Rep. 3, 32 p.

HARADA, T., H. KMAI, and M. NAKAMURA.

1973. On the rearing of bluefin tuna and bonito in wire netting cage. Mem. Fac. Agric. Kinki Univ. 6:117-122.

HARADA, T., O. MURATA, and S. MIYASHITA.

1974. On the artificial fertilization and rearing of larvae in bonito. Mem. Fac. Agric. Kinki Univ. 7:1-4.

HEIMANN, R. F. G., and J. G. CARLISLE, JR.

1970. The California marine fish catch for 1968 and historical review 1916-68. Calif. Dep. Fish Game, Fish Bull. 149, 70 p.

HILDEBRAND, S. F.

1946. A descriptive catalog of the shore fishes of Peru. U.S. Natl. Mus. Bull. 189, $530 \mathrm{p}$.

IDYLL, C. P., and D. DE SYLVA.

1963. Synopsis of biological data on bonito Sarda sarda (Bloch) 1793 (Western Atlantic). FAO Fish. Rep. 6, 2:755-760.

INOUE, M., R. AMANO, Y. IWASAKI, and M. AOKI

1967. Ecology of various tunas under captivity-I. Preliminary rearing experiments. [In Jpn., Engl. abstr.] J. Coll. Mar. Sci. Technol., Tokai Univ. 2:197-209.

INOUE, M., Y. IWASAKI, R. AMANO, M. AOKI, and M. YAMAUTI. 1970. Ecology of various tunas under captivity-II. Behaviour of tuna shown against light and darkness. [In Jpn., Engl. abstr.] J. Coll. Mar. Sci. Technol., Tokai Univ. 4:53-58.

IONESCU, M., N. GADDOV, and S. STĂNESCU.

1958. Contribution to knowledge of the biology of the bonito Sarda sarda Bloch, and of the fishery for it in the Rumanian waters of the Black Sea between 1954 and 1956. [In Rum.; Fr. and Russ. summ.] Hydrobiol., Bucuresti 1:165-186.

JONES, $\mathrm{S}$

1960. Notes on eggs, larvae and juveniles of fishes from Indian waters. VI. Genus Auxis Cuvier. VII. Sarda orientalis (Temminck \& Schlegel). Indian J. Fish. 7:337-347. (Issued 1961.)

KIKAWA, S., and STAFF OF THE NANKAI REGIONAL FISHERIES RESEARCH LABORATORY.

1963. Synopsis of biological data on bonito Sarda orientalis Temminck and Schlegel 1842. FAO Fish Rep. 6, 2:147-156

KISHINOUYE, $\mathrm{K}$.

1923. Contributions to the comparative study of the so-called scombroid fishes. J. Coll. Agric., Imp. Univ. Tokyo 8:293-475.

KLAWE, W. L.

1961a. Young scombroids from the waters between Cape Hatteras and Bahama Islands. Bull. Mar. Sci. Gulf Caribb. 11:150. 157. 
1961b. Notes on larvae, juveniles, and spawning of bonito (Sarda) from the eastern Pacific Ocean. Pac. Sci. 15:487-493.

1962. Bonito juvenil (Sarda chiliensis) en las aguas del sur de Baja California. Ciencia (Mex. City) 21:180.

KLAWE, W. L., and B. M. SHIMADA.

1959. Young scombroid fishes from the Gulf of Mexico. Bull. Mar Sci. Gulf Caribb. 9:100-115.

KROTOV, A. V.

1957. Les recherches sovíetiques sur la biologie des principaux poissons de la Mer Noire. Proc. Tech. Pap. Gen. Fish. Counc. Medit., FAO 4:427-430.

KUMARAN, M.

1964. Studies on the food of Euthynnus affinis affinis (Cantor), Auxis thazard (Lacépede), Auxis thynnoides Bleeker and Sarda orientalis (Temminck and Schlegal). Proc. Symp. Scombroid Fishes, Part 2. Mar. Biol. Assoc. India, Symp. Ser. 1:599-606.

KUO, C.-M

1970. Taxonomic, growth, and maturation studies on the bonitos of the temperate eastern Pacific Ocean. Ph.D. Thesis., Univ. California, San Diego, 321 p.

KUTAYGIL, N.

1967. Preliminary age analysis of Mullus barbatus L. and Merluccius merluccius L. in the Sea of Marmara and some pelagic fish of Turkey. Proc. Tech. Pap. Gen. Fish. Counc. Medit., FAO 8:361383.

LAEVASTU, T., and H. ROSA, JR.

1963. Distribution and relative abundance of tunas in relation to their environment. FAO Fish. Rep. 6, 3:1835-1851.

MacCALL, A. D., G. D. STAUFFER, and J.-P. TROADEC.

1976. Southern California recreational and commercial marine fisheries. Mar. Fish. Rev. 38(1):1-32.

MAGNUSON, J. J., and J. G. HEITZ.

1971. Gill raker apparatus and food selectivity among mackerels, tunas, and dolphins. Fish. Bull., U.S. 69:361-370.

MAGNUSON, J. J., and J. H. PRESCOTT.

1966. Courtship, locomotion, feeding and miscellaneous behaviour of Pacific bonito (Sarda chiliensis). Anim. Behav. 14:54-67.

MANN F., G.

1954. La vida de los peces en aguas Chilenas. 2d ed. Minist. Agric., Santiago, 339 p.

MARSHALL, T. C

1964. Fishes of the Great Barrier Reef and coastal waters of Queensland. Angus and Robertson, Sydney, 566 p. (Also 1965, Livingston Publ. Co., Narbeth.)

MATSUMOTO, W. M., F. H. TALBOT, B. B. COLLETTE, and R. S. SHOMURA.

1969. Pacific bonito (Sarda chiliensis) and skipjack tuna (Katsuwonus pelamis) without stripes. Copeia 1969:397-398.

MAYOROVA, A. A., and K. S. TKACHEVA.

1959. Distribution and conditions of reproduction of pelamid (Sarda sarda) in the Black Sea according to data for the period 1956-1957. Proc. Tech. Pap. Gen. Fish. Counc. Medit., FAO 5:509-514.

McKENZIE, R. A.

1959. Marine and freshwater fishes of the Miramichi River and estuary, New Brunswick. J. Fish. Res. Board Can. 16:807-833.

MITO, S.

1961. Pelagic fish eggs from Japanese waters. II. Lamprida, Zeida, Mugilina, Scombrina, Carangina and Stromateina. [In Jpn. Engl. summ.] Sci. Bull. Fac. Agric. Kyushu Univ. 18:451-466.

MUNRO, I. S. R.

1958. Handbook of Australian fishes, No. 28:113-116. Fish Newsl. 17(10):17-20.

NICHOLS, J. T., and C. M. BREDER, JR

1927. The marine fishes of New York and southern New England. Zoologica (N.Y.) 9:1-192.

NIKOLOV, D. C.

1960. Biologie des Pelamiden (Sarda sarda Bloch) in Schwarz meer. [In Bulg., Russ. and Ger. summ.] Tr. Tsentr. Nauch.Izsl. Inst. Rib. Varna 3:91-115.

NIKOLSKII, G. W.

1957. Spezielle Fishchkunde. Berlin, VEB Deutscher Verlag der Wissenschaften, 632 p. [German translation of Russian book.]
NÜMANN, W.

1955. Croissance et migrations des pelamides (Sarda sarda) dans les eaux de la Turquie. Proc. Tech. Pap. Gen. Fish. Counc. Medit., FAO 3:377-379.

OGILBY, J. D.

1954. The commercial fishes and fisheries of Queensland. Revised by T. C. Marshall, Brisbane (Gov. Printer) 1954, 121 p.

OLIPHANT, M. S., and MARINE FISHERIES STATISTICS STAFF 1973. California marine fish landings for 1971. Calif. Dep. Fish Game, Fish Bull. 159, 49 p.

ORTON, G. L

1953a. Development and migration of pigment cells in some teleost fishes. J. Morphol. 93:69-99.

1953b. The systematics of vertebrate larvae. Syst. Zool. 2:63-75.

PADOA, E.

1956. Divisione; Scombriformes. Monografia-Uova, larve e stadi giovanili di Teleostei. Fauna e Flora del Golfo di Napoli 38:471 521. (Engl. transl. by J. P. Wise and G. M. Ranallo, 1967, Trop. Atl. Biol. Lab., Bur. Commer. Fish., Miami, Fla. Transl. No. 12 49 p.)

PEARSE, A. S.

1952. Parasitic crustacea from the Texas coast. Publ. Inst. Mar. Sci. Univ. Texas 2(2):5-42.

PINKAS, L.

1961. Descriptions of postlarval and juvenile bonito from the eastern Pacific Ocean. Calif. Fish Game 47:175-188.

1970. The California marine fish catch for 1969 . Calif. Dep. Fish Game, Fish Bull. 153, 47 p.

1974. California marine fish landings for 1972. Calif. Dep. Fish Game, Fish Bull. 161, 53 p.

PINKAS, L., M. S. OLIPHANT, and C. W. HAUGEN.

1968. Southern California marine sportfishing survey: private boats, 1964; shoreline, 1965-66. Calif. Dep. Fish Game, Fish Bull. $143,42 \mathrm{p}$

PINKAS, L., M. S. OLIPHANT, and I. L. K. IVERSON.

1971. Food habits of albacore, bluefin tuna, and bonito in California waters. Calif. Dep. Fish Game, Fish Bull. 152, 105 p.

POSTEL, E

1954. Contribution à l'étude des thonidés de l'Atlantique tropical. J. Cons. 19:356-362.

1955a. Contribution à l'étude de la biologie de quelques Scombridae de l'Atlantique tropico-oriental. Ann. Stn. Océanogr. Salammbô 10, 167 p.

1955b. Contribution à l'étude des thonidés de l'Atlantique tropical (deuxième note). Rapp. P.V. Réun. Cons. Int. explor. Mer 137:31-32.

RADOVICH, J.

1963. Effects of water temperature on the distribution of some scombrid fishes along the Pacific coast of North America. FAO Fish. Rep. 6, 3:1459-1475.

RAO, K. V. N

1964. An account of the ripe ovaries of some Indian tunas. Proc. Symp. Scombroid Fishes, Part 2. Mar. Biol. Assoc. India, Symp. Ser. 1:733-743.

RODRÍGUEZ-RODA, J.

1966. Estudio de la bacoreta, Euthynnus alleteratus (Raf.) bonito, Sarda sarda (Bloch) y melva, Auxis thazard (Lac.), capturados por las almadrabas españolas. [Engl. summ.] Invest. Pesq. 30:247. 292.

ROSA, H., JR.

1965. Preparation of synopses on the biology of species of living aquatic organisms. FAO Fish. Synop. 1, Rev. 1, 75 p.

SANZO, L.

1932. Uova e primi stadi larvali di Pelamys sarda C. V. R. Com. Talassogr. Ital. Mem. 188:3-9.

SCHAEFER, M. B.

1954. Some aspects of the dynamics of populations important to the management of the commercial marine fisheries. [In Engl. and Span.] Inter-Am. Trop. Tuna Com., Bull. 1:27-56.

SERBETIS, $\mathrm{C}$

1955. Migrations des pélamides et des maquereaux de la mer Egée. [Engl. abstr.] Proc. Tech. Pap. Gen. Fish. Counc. Medit., FAO 3:381-385. 
SERIENTY, D. L.

1941a. The Australian tunas. Aust. Counc. Sci. Ind. Res., Div. Fish. Rep. 104, 48 p.

1941b. Victorian tunas and some recent records. Victorian Nat. 58:51-55.

SETTE, O. E

1943. Biology of the Atlantic mackerel (Scomber scombrus) of North America, Part 1: Early life history, including the growth, drift, and mortality of the egg and larval populations. U.S. Fish Wildl. Serv., Fish. Bull. 50:149-237.

SILAS, E. G.

1963. Synopsis of biological data on oriental bonito Sarda orientalis (Temminck and Schlegel) 1842 (Indian Ocean). FAO Fish. Rep. 6, 2:834-861.

1964. Aspects of the taxonomy and biology of the oriental bonito Sarda orientalis (Temminck and Schlegel). Proc. Symp. Scombroid Fishes, Part 1. Mar. Biol. Assoc. India, Symp. Ser. 1:283308.

1967. Parasites of scombroid fishes. Part 1. Monogenetic trematodes, digenetic trematodes, and cestodes. Proc. Symp. Scombroid Fishes, Part 3. Mar. Biol. Assoc. India, Symp. Ser. 1:799875.

SILAS, E. G., and A. N. P. UMMERKUTTY.

1967. Parasites of scombroid fishes. Part 2. Parasitic Copepoda. Proc. Symp. Scombroid Fishes, Part 3. Mar. Biol. Assoc. India, Symp. Ser. 1:876-993.

SIVASUBRAMANIAM, $\mathrm{K}$.

1966. Distribution and length-weight relationships of tunas and tuna-like fishes around Ceylon. Bull. Fish. Res. Stn., Ceylon 19(1-2):27-46.

1969. Occurrence of oriental bonito (Sarda orientalis Temminck and Schlegel) in the inshore waters of Ceylon. Bull. Fish. Res. Stn., Ceylon 20(1):73-77.

SKILLMAN, R. A.

1975. An assessment of the South Pacific albacore, Thunnus alalunga, fishery, 1953-72. Mar. Fish. Rev. 37(3):9-17.

SLASTENENKO, E.

1956. The fishes of the Black Sea basin. Istanbul, $711 \mathrm{p}$.

SMITH, A. C.

1971. The soluble proteins in eye lens nuclei of albacore, bluefin tuna and bonito. Comp. Biochem. Physiol. 39B:719-724.

SMITH, J. L, B.

1949. The sea fishes of southern Africa. Central News Agency, Ltd., South Africa, $550 \mathrm{p}$.

SOKOLOVSKII, A. S.

1971. Spawning of the bonito, Sarda lineolata Girard, in Californian waters. [In Russ.] Izvest. Tikhook. Nauchno-Issled. Inst. Rybn. Khoz. Okean. (Izv. TIRO) 79:172-174.

SQUIRE, J. L., JR.

1972. Apparent abundance of some pelagic marine fishes off the southern and central California coast as surveyed by an airborne monitoring program. Fish. Bull., U.S. 70:1005-1119.

SVERDRUP, H. U., M. W. JOHNSON, and R. H. FLEMING.

1942. The oceans. Their physics, chemistry and general biology. Prentice-Hall, Inc., N.Y., 1087 p.
TKACHEVA, K. C.

1958. Conditions of pelamid stocksin the Black Sea and fishery prospectives. Rybn. Khoz. 34(12):10-13.

TOMINAGA, S.

1943. Bonitos. [In Jpn.] Kaiyo no Kagaku 3(10):460-465.

TÜRGAN, S.

1958. The age determination of bonitos and pelamis. [In Turk.] Balik. Balikcilik 6(3):18-20.

VERVOORT, W.

1971. New hosts for Ceratocolax euthunni Vervoort 1965 (Copepoda, Cyclopoida). Crustaceana 21:223.

VILDOSO. A. C. DE

1960. Casos de hermafroditismo en el bonito (Sarda chilensis C. y V.). Pesca y Caza, Lima 10:111-114.

1962. Estudios sobre bonitos, Sarda en el Pacifico oriental. Bachelor's Thesis, Univ. May, San Marcos.

1963a. Estudios sobre la reproducción del bonito Sarda chilensis (C. y V.) en aguas adyacentes a la costa Peruana. FAO Fish. Rep. 6, 3:1143-1152.

1963b. Especies del genero Sarda en el Pacifico oriental. FAO Fish. Rep. 6, 3:1549-1556.

1966. Estudios sobre la reproduccion del "bonito" Sarda chilensis (C. y V.) en aguas adyacentes a la costa Peruana. Minist. Agric. (Peru), Serv. Div. Cient. 14(2d ed.), 75 p.

VODIANITSKI, V. A., and I. I. KAZANOVA.

1954. Diagnostic descriptions of the eggs and larvae of the Black Sea fishes. [In Russ. Tr. VNIRO 28:240-323. (Engl. transl. of sections pertaining to bonito and bluefin tuna by W. L. Klawe, 1969, 7 p.; Inter-Am. Trop.Tuna Comm., La Jolla, Calif.)

WALFORD, L. A.

1936. On the bonitos (Sarda) of the Pacific Ocean. St. Barbara Mus. Nat. Hist., Occas. Pap. 4, Part III, p. 8-10.

WARFEL, H. E.

1950. Outlook for development of a tuna industry in the Philippines. U.S. Fish Wildl. Serv., Res. Rep. 28, 37 p.

WHITLEY, G. P.

1964. Scombroid fishes of Australia and New Zealand. Proc. Symp. Scombroid Fishes, Part I. Mar. Biol. Assoc. India, Symp. Ser. 1:221-253.

YABE, H., N. ANRAKU, and T. MORI.

1953. Scombroid youngs found in the coastal seas of Aburatsu, Kyushu, in summer. [In Jpn.] Contrib. Nankai Reg. Fish. Res. Lab. 11, 10 p.

YOKOTA, T., M. TORIYAMA, F. KANAI, and S. NOMURA.

1961. Studies on the feeding habit of fishes. [In Jpn.] Rep. Nankai Reg. Fish. Res. Lab. 14:1-234.

YOUNG, P. H.

1969. The California partyboat fishery 1947-1967. Calif. Dep. Fish Game, Fish Bull. 145, 91 p.

ZUSSER, S. G.

1954. Biology and fishery for bonito in the Black Sea. [In Russ.] Tr. VNIRO 28:160-174. 




\section{FISHERIES SYNOPSES}

This series of documents, issued by FAO, CSIRO, INP, and NMFS, contains comprehensive reviews of present knowledge on species and stocks of aquatic organisms of present or potential economic interest. The Fishery Resources and Environment Division of FAO is responsible for the overall coordination of the series. The primary purpose of this series is to make existing information readily available to fishery scientists according to a standard pattern, and by so doing also to draw attention to gaps in knowledge. It is hoped that synopses in this series will be useful to other scientists initiating investigations of the species concerned or of related ones, as a means of exchange of knowledge among those already working on the species, and as the basis for comparative study of fisheries resources. They will be brought up to date from time to time as further information becomes available.

The documents of this series are issued under the following titles:

$\begin{array}{lll}\text { FAO } & & \text { Symbol } \\ \text { CSIRO } & \text { Fisheries Synopsis No. } & \text { FIR/S } \\ \text { INP } & \text { Fisheries Synopsis No. } & \text { DFO/S } \\ \text { NMFS } & \text { Sinopsis sobre la Pesca No. } & \text { INP/S } \\ & \text { Fisheries Synopsis No. } & \text { NMFS/S }\end{array}$

Synopses in this series are compiled according to a standard outline described in Flb/S1 Rev. 1 (1965). FAO, CSIRO, INP, and NMFS are working to secure the cooperation of other organizations and of individual scientists in drafting synopses on species about which they have knowledge, and welcome offers of help in this task. Additions and corrections to synopses already issued will also be most welcome. Comments on individual synopses and requests for information should be addressed to the coordinators and editors of the issuing organizations, and suggestions regarding the expansion or modification of the outline to FAO:

FAO:

Fishery Resources and Environment Division Aquatic Resources Survey and Evaluation Service Food and Agriculture Organization of the United Nations Via delle Terme di Caracalla 00100 Rome, Italy

INP:

Instituto Nacional de Pesca

Subsecretaria de Pesca

Secretaria de Pesca

Secretaria de Industria y Comercio

Carmona y Valle 101-403

Mexico 7, D.F.
CSIRO:

CSIRO Division of Fisheries and Oceanography

Box 21

Cronulla, N.S.W. 2230

Australia

NMFS:

\section{Scientific Editor}

National Marine Fisheries Service, NOAA

Auke Bay Fisheries Laboratory

P.O. Box 155

Auke Bay, AK 99821

U.S.A.

Consolidated lists of species or groups covered by synopses issued to date or in preparation will be issued from time to time. Requests for copies of synopses should be addressed to the issuing organization; except for NMFS/S copies, these can be purchased from National Technical Information Service, U.S. Department of Commerce, 5285 Port Royal Road, Springfield, VA 22151.

The following synopses in this series have been issued since January 1977:

FIR/S 113

NMFS/S 116

NMFS/S 117

NMFS/S 123

NMFS/S 122
Synopsis of biological data on the perch, Perca fluviatilis and flavescens Synopsis of biological data on the red porgy, Pagrus pagrus (Linnaeus) Synopsis of biological data for the winter flounder, Pseudopleuronectes americanus (Walbaum)

Synopsis of biological data on the rock crab, Cancer irroratus Say Synopsis of biological data on tunas of the genus Euthynnus
December 1977 May 1978

November 1978

May 1979

October 1979 


\section{UNITED STATES \\ DEPARTMENT OF COMMERCE}

PENN STATE UNIVERSITY LIBRARIES

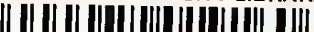

\|\|

ATIONAL OCEANIC AND ATMOSPHERIC ADMINISTRATION

NATIONAL MARINE FISHERIES SERVICE

SCIENTIFIC PUBLICATIONS STAFF

1700 WESTLAKE AVE. N., ROOM 336

SEATTLE, WA 98109

OFFICIAL BUSINESS

POSTAGE AND FEESPAID
US DEPARTMENT OF COMMERC

$\operatorname{com} 210$

THIRD CLASS

BULK RATE

\section{NOAA SCIENTIFIC AND TECHNICAL PUBLICATIONS}

The National Oceanic and Atmospheric Administration was established as part of the Department of Commerce on Octuber 3,1970. The mission responsibilitics of NOAA arc to assess the socioeconomic impact of natural and technological changes in the environment and to monitor and predict the state of the solid Earth. the oceans and their living resources, the atmosphere. and the space environment of the Earth.

The major components of NOAA regularly produce various types of scientific and technical informauon in the following kinds of publications:

PROFESSIONAL PAPERS - Important definitive rescarch results, major Icchniques, and special investigations.

CONTRACT AND GRANT REPORTS - Reports prepared by contractors or grantees under NOAA sponsorship.

ATLAS - Presentation of analyzed data generally in the form of maps showing distribution of rainfall, chemical and physical conditions of oceans and atmosphere, distribution of fishes and marine mammals, ionospheric conditions, etc.
TECHNICAL SERVICE PUBLICATIONS - Reports containing data. observations, instructions, etc. A partial listing includes data serials; prediction and outlook periodicals; technical manuals, training papers, planning reports, and information serials: and miscellaneous technical publications.

TECHNICAL REPORTS - Journal quality with extensive details, mathematical developments, or data listings.

TECHNICAL MEMORANDUMS - Reports of preliminary, partial, or negative research or technology results, interim instructions, and the like.

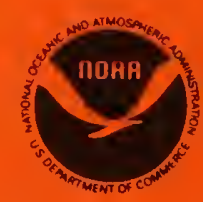

Information on availability of NOAA publications can be obtained from:

ENVIRONMENTAL SCIENCE INFORMATION CENTER (D822)

ENVIRONMENTAL DATA AND INFORMATION SERVICE

NATIONAL OCEANIC AND ATMOSPHERIC ADMINISTRATION

U.S. DEPARTMENT OF COMMERCE

6009 Executive Boulevard

Rockville, MD 20852 